\title{
The Danube Corridor Hypothesis and the Carpathian Basin: Geological, Environmental and Archaeological Approaches to Characterizing Aurignacian Dynamics
}

\author{
Wei Chu ${ }^{1}$
}

Published online: 29 May 2018

(C) The Author(s) 2018

\begin{abstract}
Early Upper Paleolithic sites in the Danube catchment have been put forward as evidence that the river was an important conduit for modern humans during their initial settlement of Europe. Central to this model is the Carpathian Basin, a region covering most of the Middle Danube. As the archaeological record of this region is still poorly understood, this paper aims to provide a contextual assessment of the Carpathian Basin's geological and paleoenvironmental archives, starting with the late Upper Pleistocene. Subsequently, it compiles early Upper Paleolithic data from the region to provide a synchronic appraisal of the Aurignacian archaeological evidence. It then uses this data to test whether the relative absence of early Upper Paleolithic sites is obscured by a taphonomic bias. Finally, it reviews current knowledge of the Carpathian Basin's archaeological record and concludes that, while it cannot reject the Danube corridor hypothesis, further (geo) archaeological work is required to understand the link between the Carpathian Basin and Central and Southeastern Europe.
\end{abstract}

Keywords Early modern humans - Danube corridor hypothesis · Carpathian Basin · Loess · Early Upper Paleolithic · Aurignacian

\section{Introduction: The Upper Paleolithic in the Carpathian Basin}

Current archaeological evidence suggests that modern humans entered Europe from East Africa either along the Mediterranean coast (Bar-Yosef 1998; Mellars 2006), through the East European Plain (Anikovich et al. 2007; Mellars 2004), and/or through a general axial trajectory along the Danube catchment from Southeastern into Central

Wei Chu

wchu@uni-koeln.de

1 Institute for Prehistory, University of Cologne, Weyertal 125, 50923 Cologne, Germany 
Europe (Conard and Bolus 2003, 2008). The last theory is supported by numerous wellstudied and well-dated early Upper Paleolithic sites in the western Danube region, for example, Hohle Fels, Willendorf II, Geißenklösterle, and Keilberg-Kirche (Conard and Bolus 2008; Higham et al. 2012; Nigst 2006; Nigst et al. 2014; Teyssandier 2004; Uthmeier 1996). Slightly older early Upper Paleolithic assemblages (Bachokirian and Kozarnikian) are also found in the lower reaches of the Danube catchment, for example, at Kozarnika, Temnata and Bacho Kiro, pointing to a hypothesized hominin starting point in Southeastern Europe (Kozłowski 2004; Kozłowski and Otte 2000). Hominin discoveries and dating projects have additionally identified an early presence of anatomically modern humans in the Middle Danube catchment, exemplified by the skeletal remains at the Peștera cu Oase (Trinkaus et al. 2003, 2012).

Still, the role of the Danube catchment in early modern human migrations is poorly understood, as the catchment's early Upper Paleolithic sites have not been verified and tested alongside the more extensive surrounding archaeological record. Current archaeological research along the Danube catchment remains limited to specific regions such as the surrounding highlands, the Inner Carpathians, Lower Austria, southern Moravia, and the Dobruja province of the lower catchment; little is known from the Basin itself (Anghelinu et al. 2012a; Ioviță et al. 2014; Steguweit et al. 2009). Additionally, although a greater emphasis on collection re-examination, site formation processes and re-dating efforts has helped to clarify erroneous sites, many findspots remain poorly understood, while others with single and multiple layers are only just being identified/re-excavated-for instance, Beregovo I and Crvenka-At (Chu et al. 2014; Usik 2008). There is also surprisingly little discussion among archaeologists about Middle Danube topographic and paleoclimatic variability that could have influenced modern human migration.

To evaluate this, data from the Middle Danube catchment, here defined as the Carpathian Basin, are compiled to explore the possible expansion of the early Upper Paleolithic from Southeastern Europe into Central Europe. Known sites are positioned within a broad synchronic perspective of modern human subsistence in the Carpathian Basin across a varied spatial, climatic and environmental context. This paper draws on archaeology, paleontology, geomorphology and climatology to explore the archaeological signal of the early Upper Paleolithic in the Carpathian Basin and to answer the questions of how the early Upper Paleolithic record of the Carpathian Basin fits into the Danube corridor hypothesis, and what avenues of research are the most promising.

\section{Geological Background and Environmental Context}

The Carpathian Basin is a back-arc basin around $200 \mathrm{~m}$ above mean sea level (mamsl), located at the intersection of the Balkan Peninsula and Central and Eastern Europe (Fig. 1). It measures roughly $400 \mathrm{~km}$ from north to south and $800 \mathrm{~km}$ from

Fig. 1 Map of the Carpathian Basin showing major physiographic features, principal early Upper Paleolithic localities and environmental proxies mentioned in the text. Red stars indicate major archaeological sites; black stars indicate minor archaeological sites. Blue circles indicate modern human remains and black circles are loess profiles (see Tables 1 and 3 for locality information). Projection is latitude-longitude WGS84; DEM is SRTM (Color figure online) 


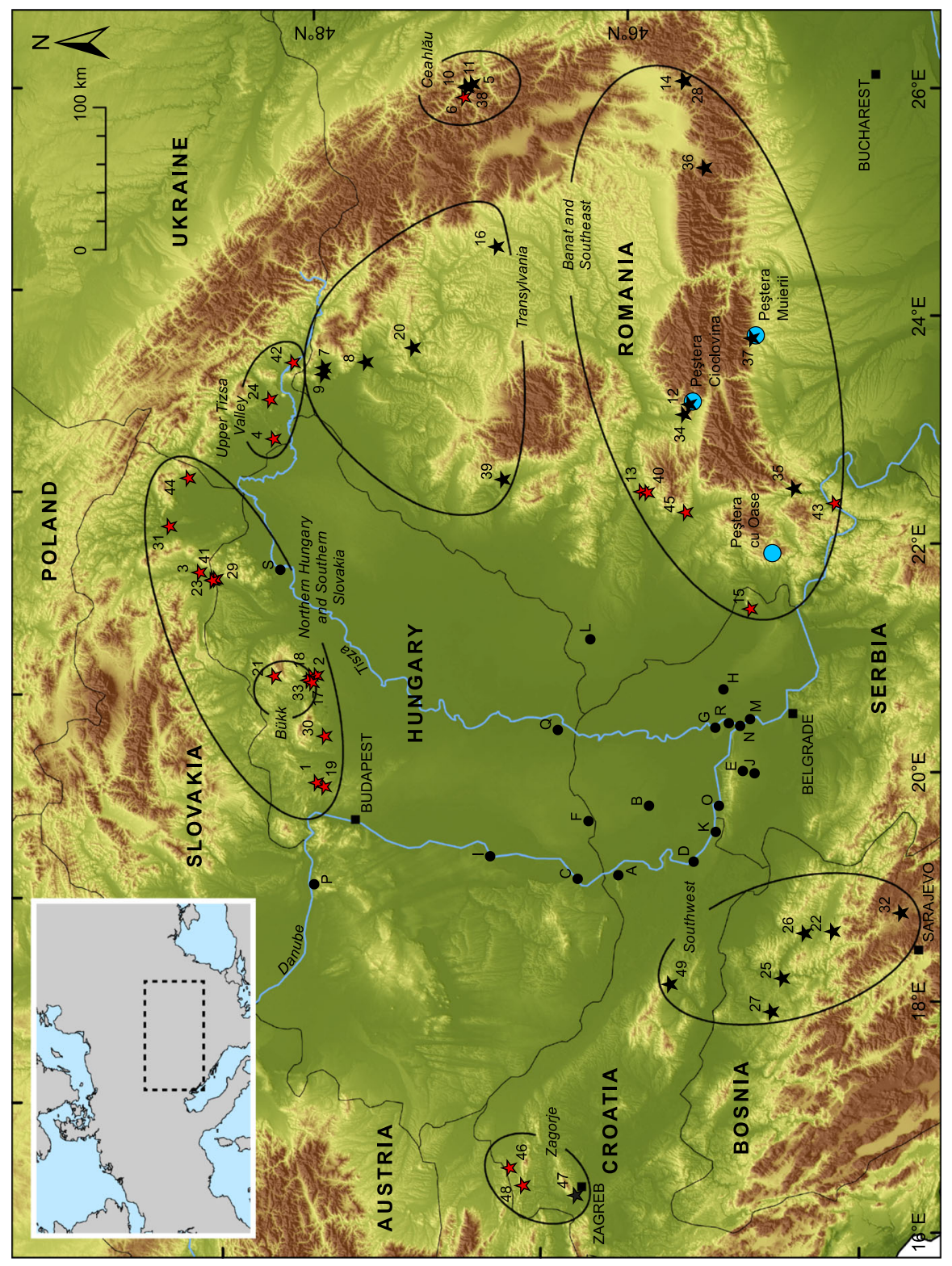


east to west and is longitudinally bisected by the Danube and Tisza rivers. Geographically, the Carpathian Basin is clearly demarcated-bounded to the north and east by the Carpathians, to the west by the Alps/Dinarides, and to the south by the Balkans. Politically, the Carpathian Basin is highly fragmented, though it is primarily located within the borders of Hungary, eastern Croatia, western Romania, southern Slovakia, northern Serbia, southwestern Ukraine and northern Bosnia and Herzegovina.

The Carpathian Basin began forming during the Late Cretaceous and Cenozoic, as a result of a collision between the Eurasian and Nubian plates (Horváth et al. 2015). Outward thrusting from the present Carpathian Basin was directed toward the European platform and the Adriatic Sea. The interior regions of the thrust belts were formed during the Mesozoic, while the exterior regions were formed later in the Early Cenozoic (Royden et al. 1982). Gradual uplift of the Carpathian Mountains resulted in subsidence associated with the Late Miocene retreat of the Paratethys Sea to form the Pannonian Lake within the rough current boundary of the Carpathian Basin (Horváth 1993).

By the beginning of the Late Miocene, as the Pannonian Lake retracted, it gave rise to the Danube and Tisza river systems and an associated interconnected paleolake system (Gábris and Nádor 2007). From the Late Pliocene until the beginning of the last glacial, the Danube, coming from the Visegrad Gorge, the Tisza River from the Eastern part of the alluvial plain, and the paleo-Bodrog River all converged on the south Tisza Graben (Kiss et al. 2015; Starkel et al. 2015).

Tectonic activity and global climatic cooling during the last glacial generally resulted in a large braided river system across the basin (Mezôsi 2017), but complex regional tectonics, riparian vegetation and climate shaped local hydrology differently. Rivers in uplifted/tectonically stable areas (broadly the western Carpathian Basin) had narrow (a few kilometers wide), incised (hundreds of meters) terraced valleys, whereas rivers in areas of net subsidence (broadly the eastern Carpathian Basin) have buried terraces with heavy sedimentation and floodplains that transformed into large, unstable alluvial plains (Perșoiu et al. 2017).

The Danube had a multi-channel, anastomosing pattern moving southeast across the current Danube-Tisza Interfluve, where it built a broad alluvial fan (Gábris 1994; Mezôsi 2017, p. 43). However, broadly 50 ka ago, tectonic activity forced the river west into its current direction, where it began to incise, leaving behind a series of (misfit) channels and dry surfaces across the abandoned eastern course (Kiss et al. 2015; Starkel et al. 2015). Thus, the former alluvial fans and floodplain levels became dry surfaces, while the low-lying areas became subject to frequent inundation.

By contrast, rivers in the subsiding Eastern Carpathian Basin were primarily meandering during the last glacial (Cserkész-Nagy 2012; Gábris et al. 2012). Optically-stimulated luminescence (OSL) dates and sediment mineralogy suggest that the Tisza ran $80 \mathrm{~km}$ east of its current trajectory c. 46-39 ka ago (Nádor et al. 2007; Timár et al. 2005) and was prone to frequent tectonically influenced local and regional channel avulsions (Gábris and Nádor 2007; Perşoiu et al. 2017). However, in the mid-altitude feeder rivers, there is evidence that between 45 and 37 ka ago, 
medium-sized rivers had shallow, gravel-bedded, braided channels (Perşoiu et al. 2017; Starkel et al. 2015).

The current course and morphology of the Danube and its main tributaries give a false impression of the size and magnitude of the Pleistocene river systems, as their regimes and planforms have changed markedly since the Holocene, due to increased seasonal flow and a switch to small-scale meanders (Perşoiu and Rădoane 2017). The Danube channels were also heavily controlled in the nineteenth century through extensive straightening and the construction of hundreds of levees and thousands of $\mathrm{km}$ of drainage canals. The most extensive of these works were along the Tisza, which was shortened by one-third (c. $500 \mathrm{~km}$ ), while its 10-100 km wide floodplain was reduced to 1-5 km (Csekö and Hayde 2004).

Nonetheless, the complex hydrological changes throughout the Quaternary in the Carpathian Basin have left an abundant sedimentary archive throughout the basin. Obtaining a cohesive understanding of the distribution of these sediments has been problematic due to differences in cross-border source data (Lindner et al. 2017). Still, a generalized picture for the area can be painted for Hungary and this can be extrapolated to the wider region. In the interior mountain areas (e.g. the North Hungarian Range), 1-25 m thick Quaternary rock fields, debris and lag gravels appear infrequently; however, in the hilly regions, 0-140 m thick sediments are comprised of nearly ubiquitous loess-paleosol complexes whose loose sediments have been prone to mass wasting. In the basin, the surface of the higher alluvial fans and low-lying floodplains are made up of fine and coarse Quaternary fluvial sediments, whose thickness varies between 20 and 750 m (Jámbor 2012).

This large amount of sedimentation in the Carpathian Basin, along with a lack of appropriate geoarchaeological methods, has partly impeded the discovery of openair sites. While geochemical and microscopic methods have gained traction in recent years, geoarchaeological research in the Carpathian Basin at a landscape scale has mostly focused on tracing raw materials sources. However, many parts of the Carpathian Basin have not been systematically surveyed, and advanced geophysical techniques focused on locating new sites are still relatively unused (e.g. remote sensing, magnetometry, electrical resistivity and ground-penetrating radar). Additionally, the application of other field-based and laboratory methods to elucidate site formation processes is also uncommon, which has been problematic for the comprehensive understanding of site integrities and chronometric datings.

\section{Environmental Context}

As the focus of this paper is the early modern human occupation of the Carpathian Basin, it is important to review late Upper Pleistocene climatic data to understand the capacity, challenges and limitations for early humans inhabiting the region (Müller et al. 2011). There are few methods of describing in detail the changes in Pleistocene climatic conditions, due to the relatively rare occurrence of floral and faunal remnants. As a result, the bulk of Pleistocene paleoclimatic reconstructions for the Carpathian Basin are based upon loess deposits-fine-grained, friable, windblown sediment accretions that cover many parts of the globe, and which in the Carpathian Basin can be tens of meters thick (Marković et al. 2015; Pye 1984; 
Rózycki and Wydzia 1991). It is generally accepted that some of the longest, most continuous and best-studied loess deposits in Europe are found in the Carpathian Basin (Fitzsimmons et al. 2012; Marković et al. 2012a, b, 2014).

Loess, particularly when carbonate-rich, is archaeologically important because Pleistocene sites, such as Willendorf II (Austria) or Mitoc-Malu Galben (Romania) are frequently embedded within deposits (Haesaerts and Teyssandier 2003; Otte et al. 2007; Nigst et al. 2014), often with extraordinary preservation (Händel et al. 2009). Loess deposits are also important because they are geographically widespread, have long sedimentary records and can be used to derive paleoenvironmental proxies (Goldberg and Macphail 2009, p. 156; Zeuner 1956). However, extracting ancient climatic details from loess records is seldom straightforward, as loess-paleosol sequences are often obscured by incongruous reworked sediments and disparate accumulation rates (Marković et al. 2015). Though loess deposits are nearly ubiquitous in the Carpathian Basin, they are rarely 'typical' (sensu Pye 1987, p. 198), having been hydraulically eroded from higher elevations and redeposited along the Danube floodplain throughout the Pleistocene (Buggle et al. 2008; Újvári et al. 2008). Therefore, loess-paleosol sequences are ideally dated using a combination of radiometric dating techniques (radiocarbon, thermoluminescence [TL], OSL, infrared stimulated luminescence [IRSL]) and multi- point/proxy correlations. Still, the conditions for providing a high dating resolution record are rarely met (Basarin et al. 2014; Buggle et al. 2009; Marković et al. 2015; Necula et al. 2013; Necula and Panaiotu 2008).

Paleoenvironmental information from loess is, at its simplest, inferred from the number and types of embedded paleosols, but changes in rock magnetism, geochemistry (biomarkers, isotopes), color, and grain size can also help to identify and characterize specific soil/sediment formations (Buggle and Zech 2015; Schatz 2014; Schatz et al. 2015; Schreuder et al. 2016; Zech et al. 2013). When present, biotic remnants such as mollusk shells (Marković et al. 2007; Molnár 2015; Sümegi et al. 2011, 2015), charcoal (Rudner and Sümegi 2001; Willis and van Andel 2004), and/or osseous remains (Jánossy 2011; Pazonyi et al. 2014) found within loesspaleosol sequences can provide further insights into the paleoenvironment.

Given the current imprecision of these techniques, it is only possible to extrapolate a generic, time-averaged paleoenvironmental reconstruction for the Carpathian Basin during marine isotope stage 3 (hereafter MIS 3). Environmental reconstructions based on oscillations in grain-size and magnetic susceptibility can be used to determine broad-scale regional climate, but finer fluctuations cannot be securely linked to North Atlantic Heinrich events without significant wigglematching, which is difficult to reconcile from a dating perspective (Blaauw 2012). Nevertheless, a combination of granulometry, geochemistry and magnetic susceptibility from regional loess studies indicates that the Carpathian Basin had a comparatively warmer, drier climate than the surrounding regions (Table 1). This may have been consistent throughout the late Upper Pleistocene, and possibly even earlier, as a result of the Carpathian uplift that created an atmospheric barrier to North Atlantic climatic patterns (Antoine et al. 2009; Buggle et al. 2013).

Still, it is likely that there was significant paleodiversity across the Carpathian Basin, as indicated by diverse loess paleosols suggesting cool-temperate biomes, 


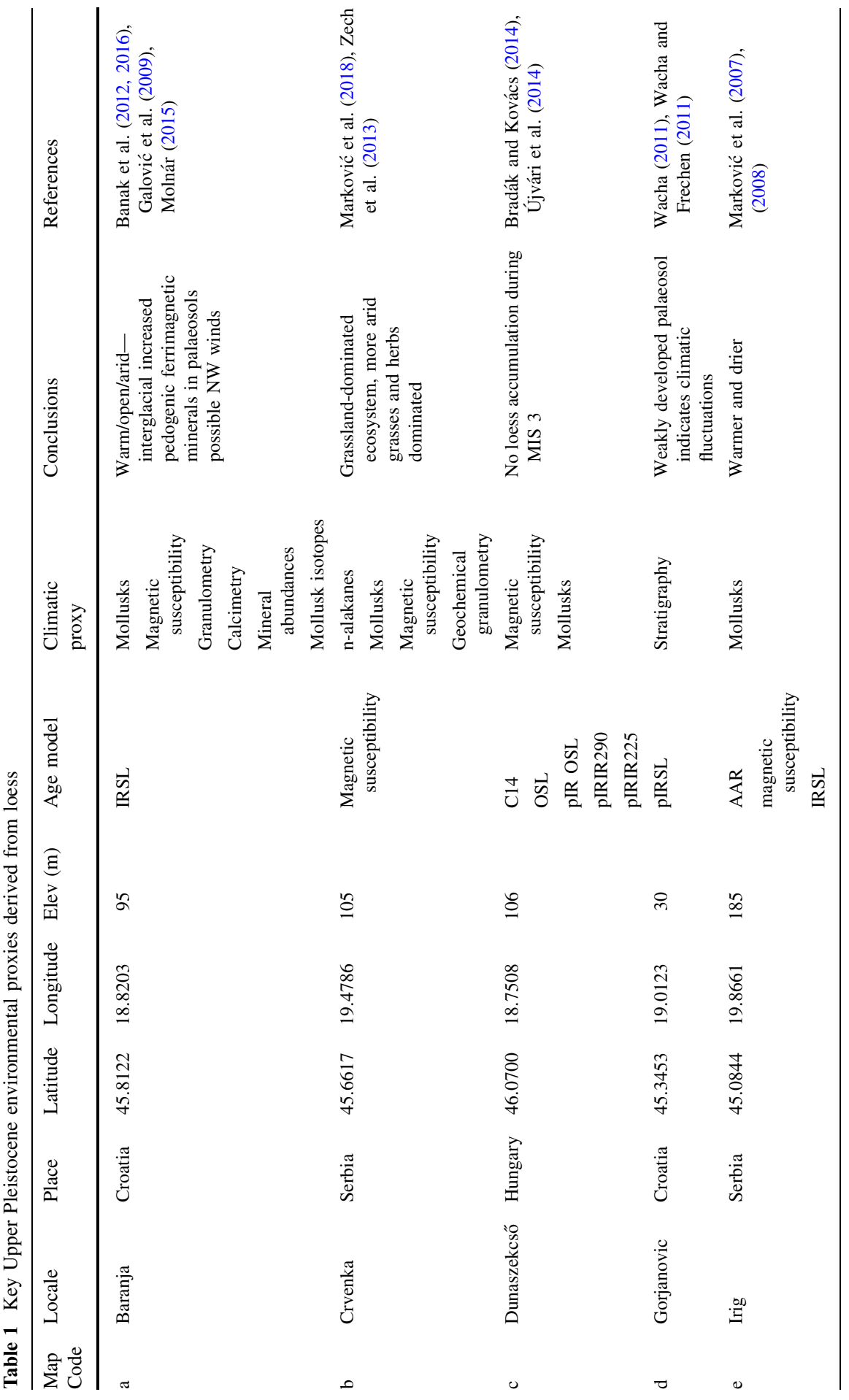




\begin{tabular}{|c|c|c|c|c|c|}
\hline 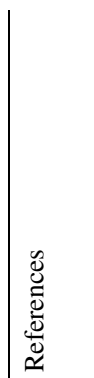 & 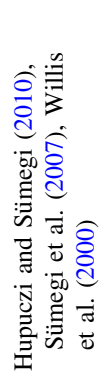 & 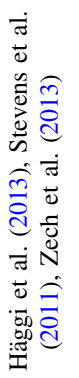 & 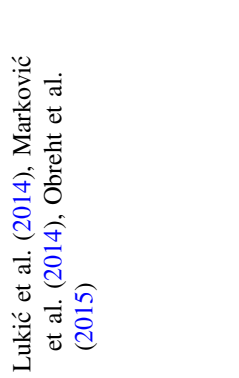 & 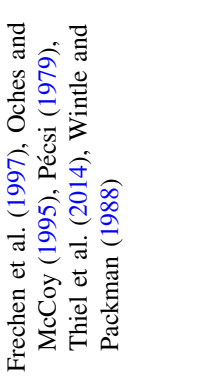 & 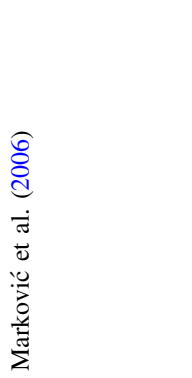 \\
\hline $\begin{array}{l}\frac{n}{0} \\
\frac{0}{0} \\
\frac{0}{0} \\
0 \\
0 \\
0\end{array}$ & 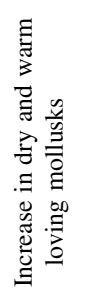 & 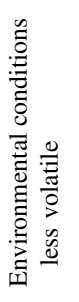 & 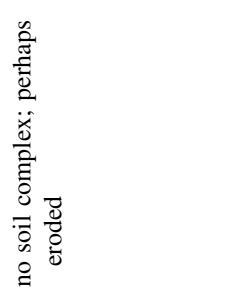 & 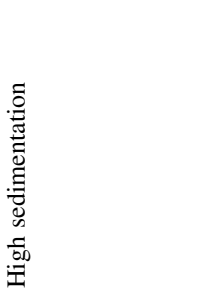 & 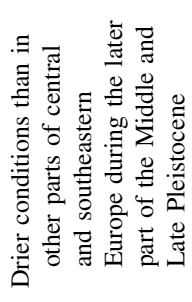 \\
\hline 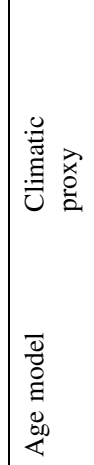 & $\frac{\tilde{y}}{\stackrel{0}{0}}$ & 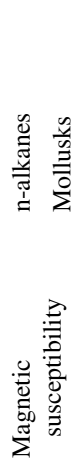 & 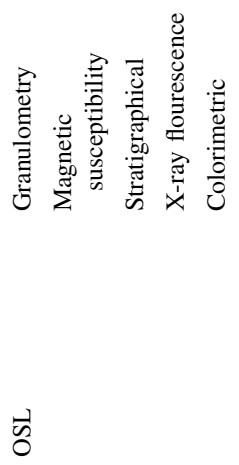 & 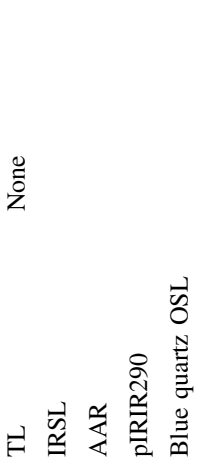 & 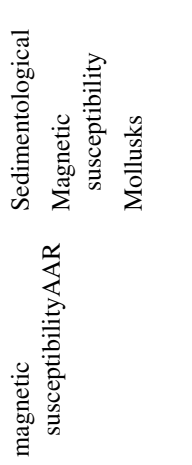 \\
\hline $\begin{array}{l}\vec{a} \\
\frac{\vec{u}}{I I}\end{array}$ & 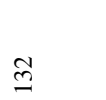 & 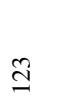 & $\infty$ & 导 & $\tilde{\Xi}$ \\
\hline 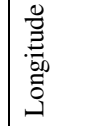 & 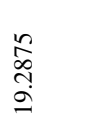 & $\begin{array}{l}\text { ָे } \\
\text { तે } \\
\stackrel{\sim}{\sim}\end{array}$ & $\begin{array}{l}\tilde{\infty} \\
\infty \\
n \\
\tilde{N}\end{array}$ & $\begin{array}{l}\infty \\
\stackrel{\infty}{\infty} \\
\infty \\
\infty \\
\infty\end{array}$ & 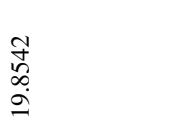 \\
\hline 胥 & 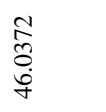 & 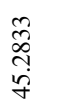 & $\begin{array}{l}8 \\
\text { on } \\
\text { w } \\
\text { yे }\end{array}$ & 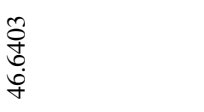 & $\begin{array}{l}8 \\
\frac{0}{0} \\
\text { id }\end{array}$ \\
\hline$\frac{\ddot{E}}{2}$ & $\begin{array}{l}\text { 死 } \\
\text { 品 } \\
\text { 至 }\end{array}$ & 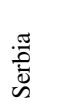 & 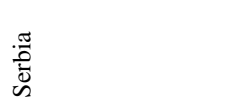 & $\begin{array}{l}\text { 䓵 } \\
\text { 至 }\end{array}$ & 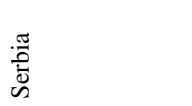 \\
\hline 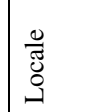 & 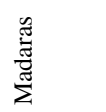 & $\begin{array}{l}\text { 志 } \\
\text { 总 } \\
\sum_{0}^{\circ}\end{array}$ & 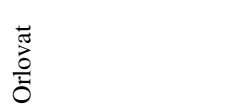 & है & $\underset{\Xi}{\stackrel{\Xi}{\Xi}}$ \\
\hline & $\psi$ & of & $=$ & &.- \\
\hline
\end{tabular}




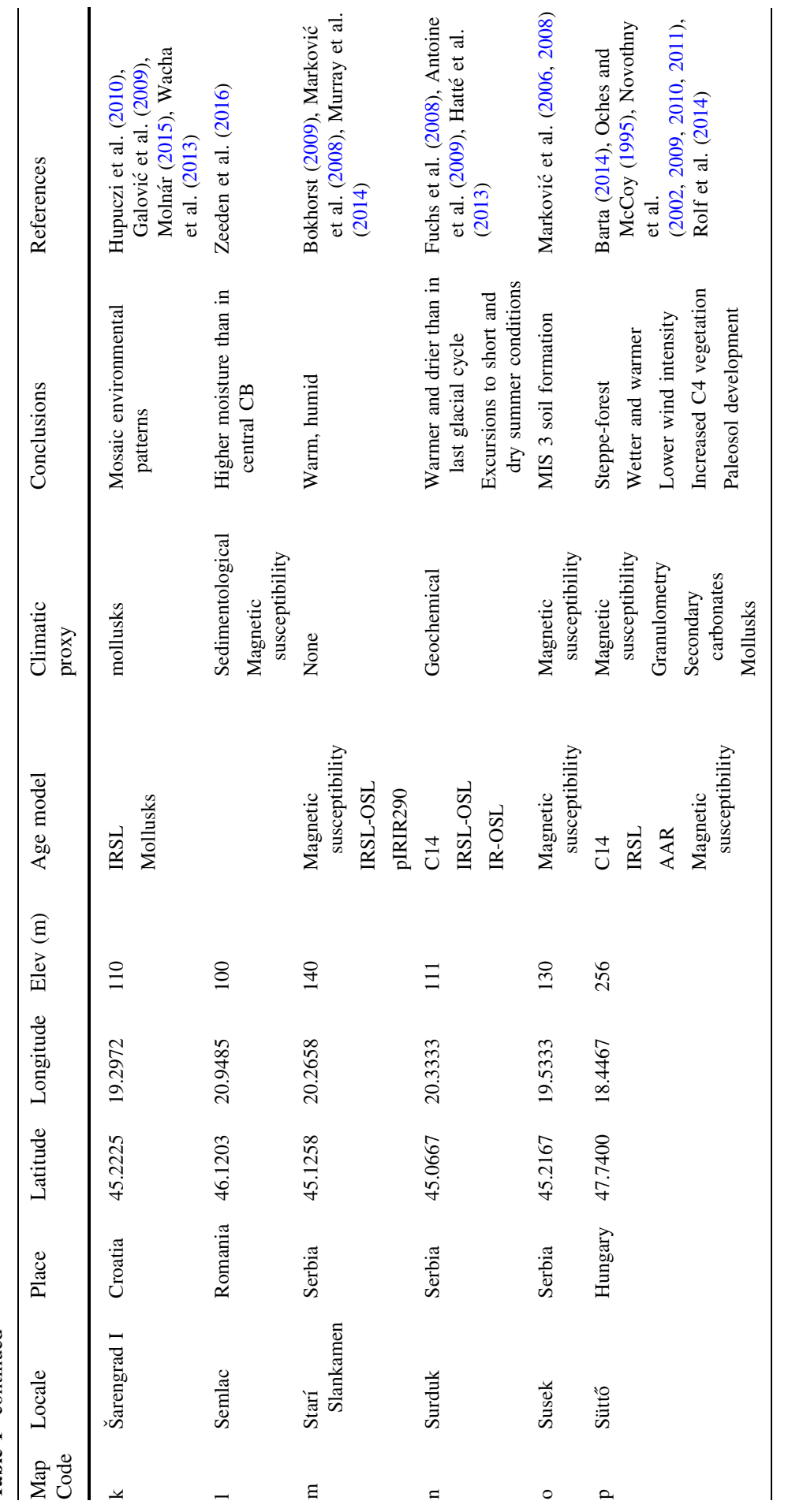




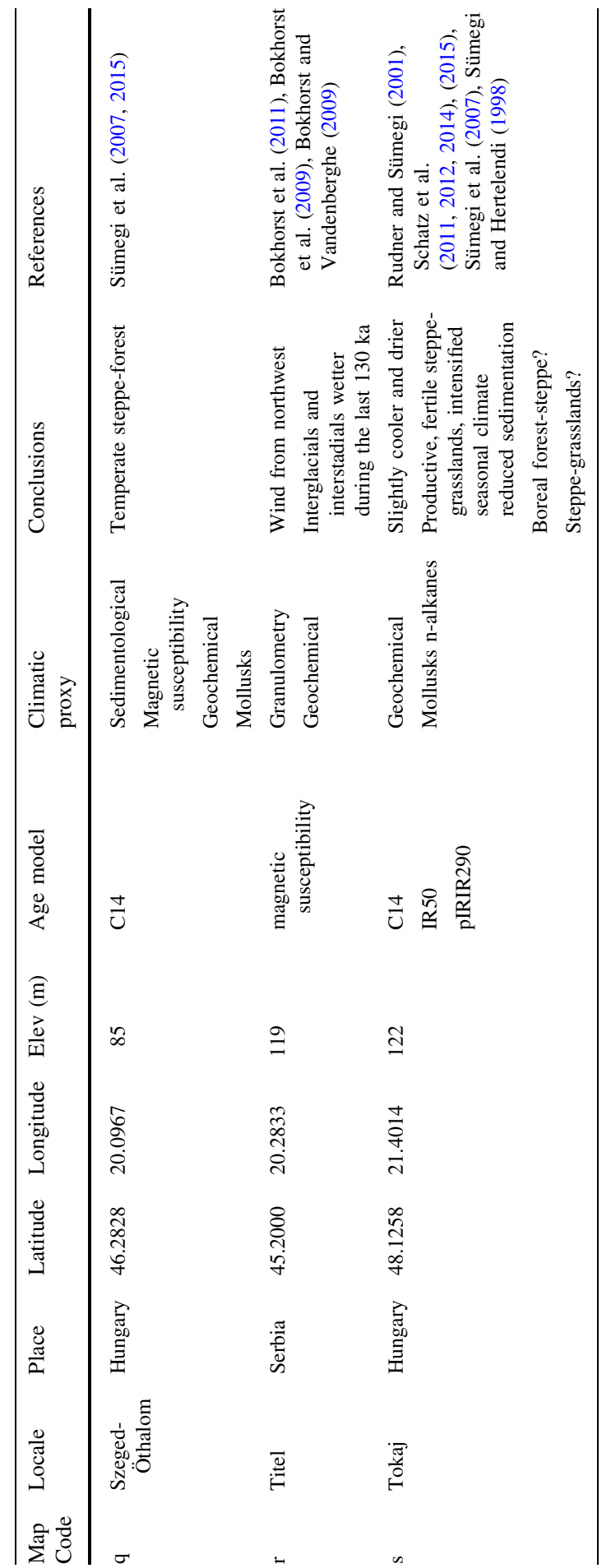


varying between steppe grasslands (Schatz et al. 2011) and forest steppe (Feurdean et al. 2014; Kels et al. 2014), and their associated ecotones. It is evident that these variations are in part due to complex geographical, geological, climatic and meteorological deviations across both space and time. Additionally, local discrepancies in geology, topography, soils, biota, aspect/exposure, wind and other variables are all essential to understanding past microclimatic variations. However, for the Late Pleistocene, these factors are largely unknown and difficult or impossible to model.

In spite of this, the general results derived from loess records mesh well with malacological studies suggesting that the Carpathian Basin was warmer and drier than other parts of Europe during MIS 3 (57-29 ka ago), with patchy mosaic-like variations in local climates (Molnár 2015; Rudner and Sümegi 2001; Willis et al. 2000; Willis and van Andel 2004). Mollusk faunal assemblages from loess sections in the southern Carpathian Basin suggest particularly warm, arid environments, and in some, thermophilic mollusks were found throughout the MIS 3 sediments, suggesting a comparatively stable environment throughout the late Upper Pleistocene.

Aside from the loess-derived proxies, there are few other climatic proxies available from this time frame. However, those that do exist largely confirm the prevailing depiction of an amenable climate. The large mammal and micromammal assemblages from the exceptional Paleolithic cave sites in northwestern Croatia (Veternica, Velika Pećina and Vindija) suggest relatively temperate environments without dramatic oscillations in faunal composition throughout MIS 3 (Miracle et al. 2010). This is additionally supported by the stable isotopes taken from the Poleva Cave stalagmite (southwestern Romania) and the closest lake-core at Lake Ochrid/Prespa in Northern Greece, which demonstrates a slight warming at $40 \mathrm{k}$ through an increase in arboreal pollen and organic input (Constantin et al. 2007; Panagiotopoulos et al. 2014). These all suggest the MIS 3 record, which in Europe is normally characterized as a period of climatic instability with dramatic alternations between milder and colder conditions at millennial or sub-millennial timescales (van Andel 2003), may have been comparatively muted in the Carpathian Basin.

A main thrust of paleoclimatic research has been to provide quantitative estimates of both paleotemperature and precipitation, for which many models have been derived from malacology and more recently from geochemistry. The main results of these studies are presented in Table 2. Using mollusk assemblages throughout the Carpathian Basin, Sümegi suggested that in the warmest month, temperatures averaged $16-19{ }^{\circ} \mathrm{C}$, while the average annual temperature hovered around $10{ }^{\circ} \mathrm{C}$-figures which, while colder, are still comparable to those today (Krolopp and Sümegi 1995; Marković et al. 2007; Sümegi and Krolopp 2002). In the eastern Tokaj region, Sümegi and Hertelendi (1998) suggest that the average July summer paleotemperatures were between 14 and $18{ }^{\circ} \mathrm{C}$, depending on topography and aspect. Mollusk paleotemperature reconstructions at Süttô also showed similar-to-present mean July temperatures $\left(21.5^{\circ} \mathrm{C}\right)$ at the Irig section, in Serbia.

Although still in a nascent phase, a recent focus of geological research has been on transfer functions which mathematically convert geochemical proxies into 
Table 2 Summary of quantitative paleoenvironmental estimates for the CB during the Late Pleistocene

\begin{tabular}{|c|c|c|c|}
\hline Parameter & Result & Method & References \\
\hline Mean annual temperature & $8.5-10^{\circ} \mathrm{C}$ & $\begin{array}{l}\text { Trace elements, MS, } \\
\quad \delta 13 \mathrm{C}\end{array}$ & Schatz et al. (2015) \\
\hline Mean annual temperature & $2-4{ }^{\circ} \mathrm{C}$ & Climate model & Frenzel et al. (1992) \\
\hline Mean July temperature & $14-16^{\circ} \mathrm{C}$ & Climate model & Frenzel et al. (1992) \\
\hline Mean July temperature & $19-19^{\circ} \mathrm{C}$ & Malacology & $\begin{array}{l}\text { Hertelendi et al. (1992) } \\
\text { Krolopp and Sümegi } \\
\text { (1995) } \\
\text { Marković et al. (2007) } \\
\text { Sümegi and Krolopp } \\
\text { (2002) }\end{array}$ \\
\hline Mean annual temperature & $9.2-9.9^{\circ} \mathrm{C}$ & Malacology & $\begin{array}{l}\text { Hertelendi et al. (1992) } \\
\text { Krolopp and Sümegi } \\
\text { (1995) } \\
\text { Marković et al. (2007) } \\
\text { Sümegi and Krolopp } \\
\text { (2002) }\end{array}$ \\
\hline Mean annual temperature & $10.4-17.4^{\circ} \mathrm{C}$ & Stable isotopes & Kovács et al. (2012) \\
\hline Mean July temperature & $14-18^{\circ} \mathrm{C}$ & Malacology & $\begin{array}{l}\text { Sümegi and Hertelendi } \\
\text { (1998) }\end{array}$ \\
\hline Mean annual temperature & $7.4-8.8^{\circ} \mathrm{C}$ & Malacology & $\begin{array}{l}\text { Sümegi and Hertelendi } \\
\text { (1998) }\end{array}$ \\
\hline Mean annual temperature & $7-14{ }^{\circ} \mathrm{C}$ & $\begin{array}{l}\text { Soil bacterial membrane } \\
\text { lipids }\end{array}$ & Schreuder et al. (2016) \\
\hline $\begin{array}{l}\text { Average growing season } \\
\text { temperature range }\end{array}$ & $9-13{ }^{\circ} \mathrm{C}$ & Mollusk/isotopes & Banak et al. (2016) \\
\hline Mean annual precipitation & $\begin{array}{l}300-500 \mathrm{~mm} \\
\mathrm{a}^{-1}\end{array}$ & $\begin{array}{l}\text { Trace elements, MS, } \\
\quad \delta 13 \mathrm{C}\end{array}$ & Schatz et al. (2015) \\
\hline Mean annual precipitation & $\begin{array}{l}250-450 \mathrm{~mm} \\
\mathrm{a}^{-1}\end{array}$ & Climate model & Frenzel et al. (1992) \\
\hline
\end{tabular}

generalized mean annual temperatures. Though their reliability and accuracy are still disputed (Schatz et al. 2015), recent studies from locations throughout the Carpathian Basin nonetheless suggest a temperature range of $2-19{ }^{\circ} \mathrm{C}$, while annual precipitation ranged from 250 to $500 \mathrm{~mm}$. Though these estimates show less precision than the malacothermometer, they do confirm that the region was slightly cooler and drier, though broadly comparable with most current European climes.

The Carpathian Basin may also have been windier during earlier parts of the last glacial, with grain-size models suggesting a dominant west-northwesterly wind over the Carpathian Basin during MIS 3 (Bokhorst et al. 2011), with the possible result that oceanic moisture input was less prominent than in the preceding interglacials (Feurdean et al. 2014). According to grain-size and sedimentation rate analyses from loess profiles across the Carpathian Basin, airborne dust concentrations were higher than those found in extant arid dusty environments. These studies also point 
to the occurrence of Late Pleistocene dust storms strong enough to have occasionally impaired visibility across the landscape (Varga et al. 2012). At present, it is difficult to extrapolate the frequency, duration or spatial extent of these storms; however, given the persistent survival of diverse flora and fauna across the Carpathian Basin, it would appear that they were both intermittent and localized.

Still, while the loess, mollusks, fauna and geochemistry offer a cohesive climatic reconstruction for MIS 3, given the poor temporal resolution it is challenging to definitively say whether the Carpathian Basin had a mosaic climate or if these various biomes represent various periods and/or palimpsests throughout MIS 3 . These uncertainties are unlikely to be resolved anytime soon without improved chronological models. Whatever the outcome of this debate, it is increasingly clear that at some point during MIS 3, the climatic conditions of the Carpathian Basin suggest an environment that would have supported ample wildlife and plant life and created a hospitable habitat for modern humans for a possible later expansion of modern humans into Central Europe.

\section{The Early Upper Paleolithic of the Carpathian Basin: Current Knowledge}

Paleolithic research in the Carpathian Basin has a long history that in its early phase (c. 1900) was part of a larger pan-European interest in the antiquity of humans (Romanowska 2016). Early scholars focused their efforts primarily on cave sites (e.g. Doboș et al. 2010, p. 21; Lengyel et al. 2008), though, as elsewhere, their excavations frequently resulted in poorly-documented, biased archaeological collections lacking in contextual information.

As archaeological research grew, the increasing geopolitical fractionation of the Carpathian Basin following World War I inhibited cross-border academic exchange, with a greater propensity to publish in local languages and national publications leading to divergent national archaeological methods and theory. Isolation meant that some countries in the Carpathian Basin never fully implemented advancing theoretical frameworks, continuing to use type fossils and adapting them to create a menagerie of local lithic industries that did not traverse national borders, complicating intraregional comparisons. Additionally, Paleolithic research was increasingly used (to different extents) to advance Marxist perspectives and to uphold ethnogeneses according to a culture-historical paradigm (Anghelinu 1998; Bartosiewicz 2016; Dragoman and Oanţă-Marghitu 2006).

Nevertheless, numerous early Upper Paleolithic sites in the Carpathian Basin are known to contain important geochronological, paleontological and archaeological evidence. The following section presents short descriptions of these sites and positions them within a regional context. These data are drawn from sites located across the Carpathian Basin within the Danube catchment (Hungary, Croatia, Slovakia, Serbia, Romania, Ukraine, and Bosnia and Herzegovina) and broadly situated across the same environmental conditions during MIS 3. This review underscores the variable quality of archaeological data reporting, with the number of lithics, assemblage compositions and stratigraphic context often being unclear or 
unreported. Thus, this study focuses on published sites defined as early Upper Paleolithic or Aurignacoid (based on retouched blades/bladelet production, carinated pieces and bone industry) and, ideally, sites for which cosmogenic dates were provided. Where available, data extracted include site location, age, type (open/cave), techno-typological attribution and radiometric dating (Table 3). Additionally, sites are ascribed a quality value based on the presence of diagnostic artifacts and independent chronological markers. The collation of this database of early Upper Paleolithic archaeological sites provides a broader structure with which to compare and contextualize the Carpathian Basin's archaeological record. This methodology not only allows for a wider reassessment of early modern human subsistence but also provides the first systematic and synchronic comparison of the role and importance of topography and climate in the modern human occupation of the Carpathian Basin.

Important locations in the Carpathian Basin are found in the regions of Romania (Banat, the Ceahlău Massif/Bistrița Valley and Transylvania), northern Hungary and southern Slovakia, Ukraine (Upper Tisza Valley), Bosnia and Herzegovina (the southwest), and the exceptional karstic cave localities of the Croatian Zagorje and Hungarian Bükk Mountains. Unfortunately, the dissociation of archaeological assemblages and the poor quality of old excavations makes it difficult to assign many of the key sites to specific time frames. Nevertheless, if correct, the radiocarbon ages of the Peștera cu Oase indicate an early modern human presence in the Carpathian Basin reaching back to at least $40 \mathrm{ka}$ ago; it is therefore important for assessing the nature and timing of the earliest modern human occupation of Europe.

\section{Banat Sites and the Southeast}

Perhaps the best-researched area of early Upper Paleolithic archaeology in the Carpathian Basin is the Banat-a historical region shared by western Romania, northwestern Serbia and southeastern Hungary, where open plains, marshes and karstic mountains coexist in close proximity (Tasić et al. 2011). Here, stratified Aurignacian sites are found close, spatially and temporally, to the multiple welldated early human remains at the Peștera cu Oase (Trinkaus et al. 2003, 2012), as well as further afield in the southeastern Carpathian Basin at Muierii and Cioclovina (Alexandrescu et al. 2010; Harvati et al. 2007; Soficaru et al. 2006, 2007; Trinkaus et al. 2009).

Românești is the best-known and most comprehensively documented Banat site. This open-air site is situated on a low terrace plateau (212 mamsl) near the confluence of two small streams, with archaeological deposits found throughout a meter-deep sequence (Fig. 2). Here, layers of Aurignacian artifacts were found intercalated between a quartzite Mousterian and Gravettian layers (Fig. 3). The largest assemblage (level III) contains thousands of lithics, refitted knapping debitage and typical Aurignacian tools suggestive of a highly-preserved knapping locale (Kels et al. 2014; Sitlivy et al. 2014a, b). No organic remains have yet been found, a situation that is not likely to change due to high soil acidity. However, OSL and TL dates of sediments and heated artifacts indirectly and directly bracket the Aurignacian levels between 42.1 and $39.1 \mathrm{ka}$ ago (Schmidt et al. 2013; Sitlivy et al. 


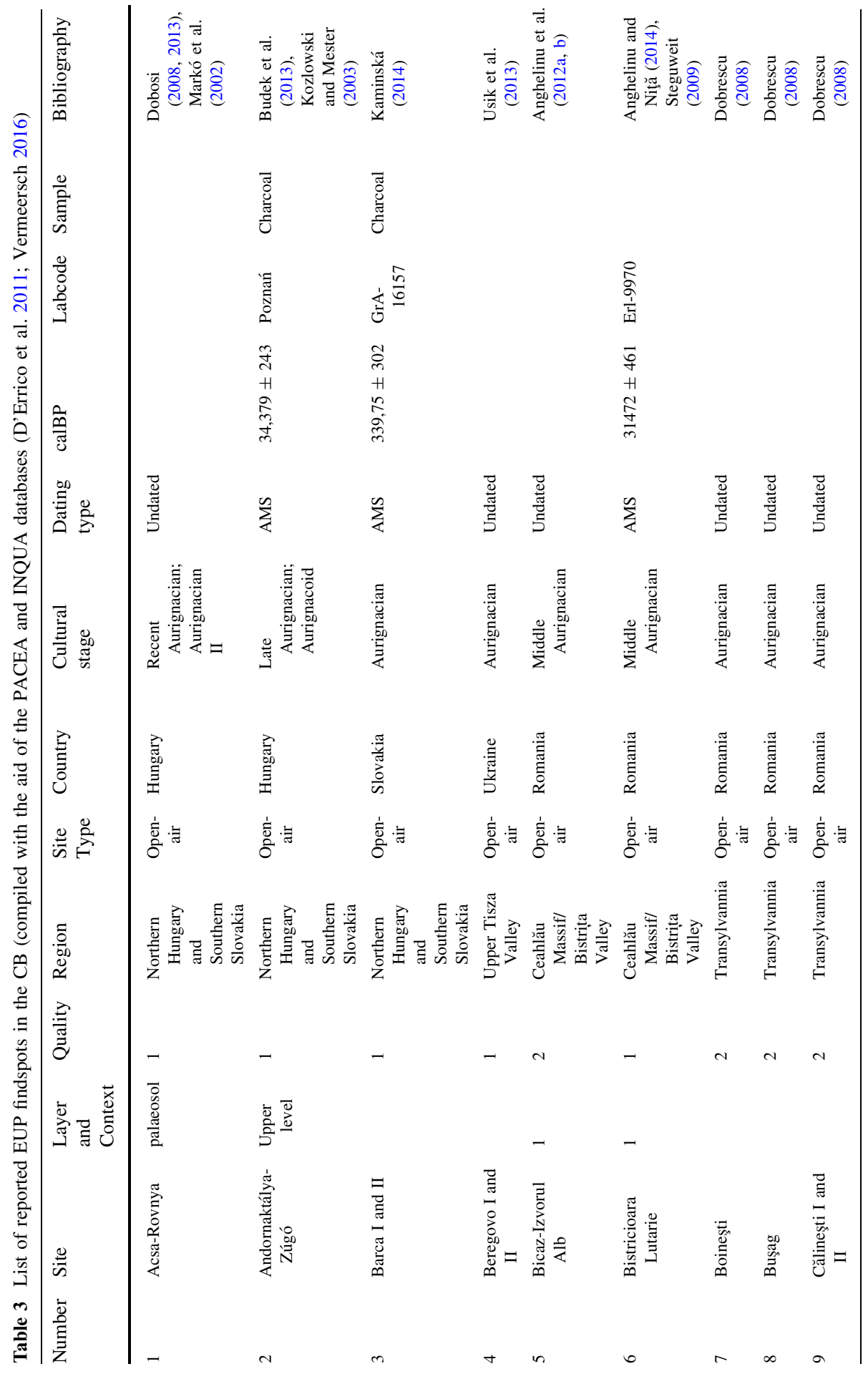




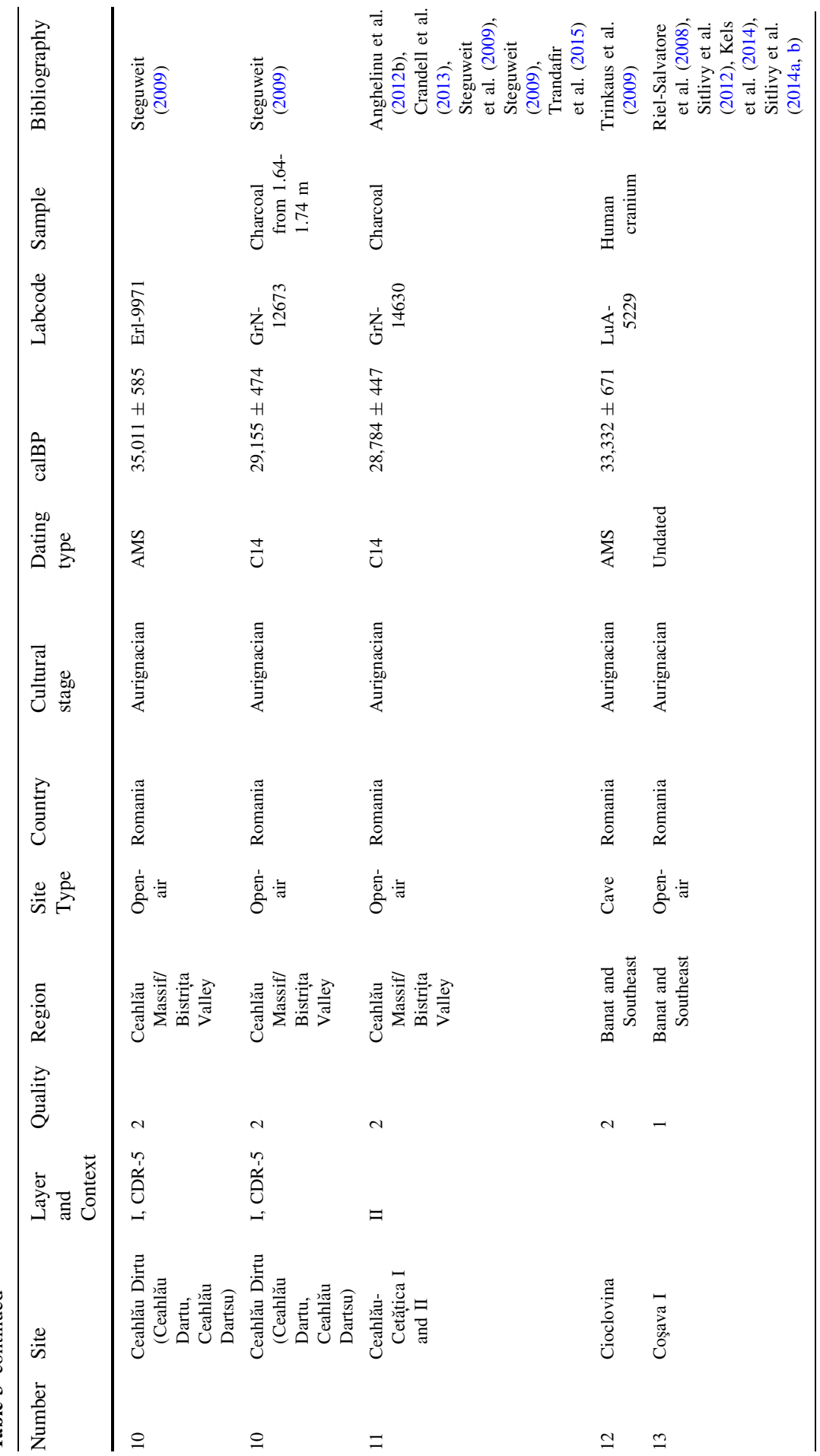




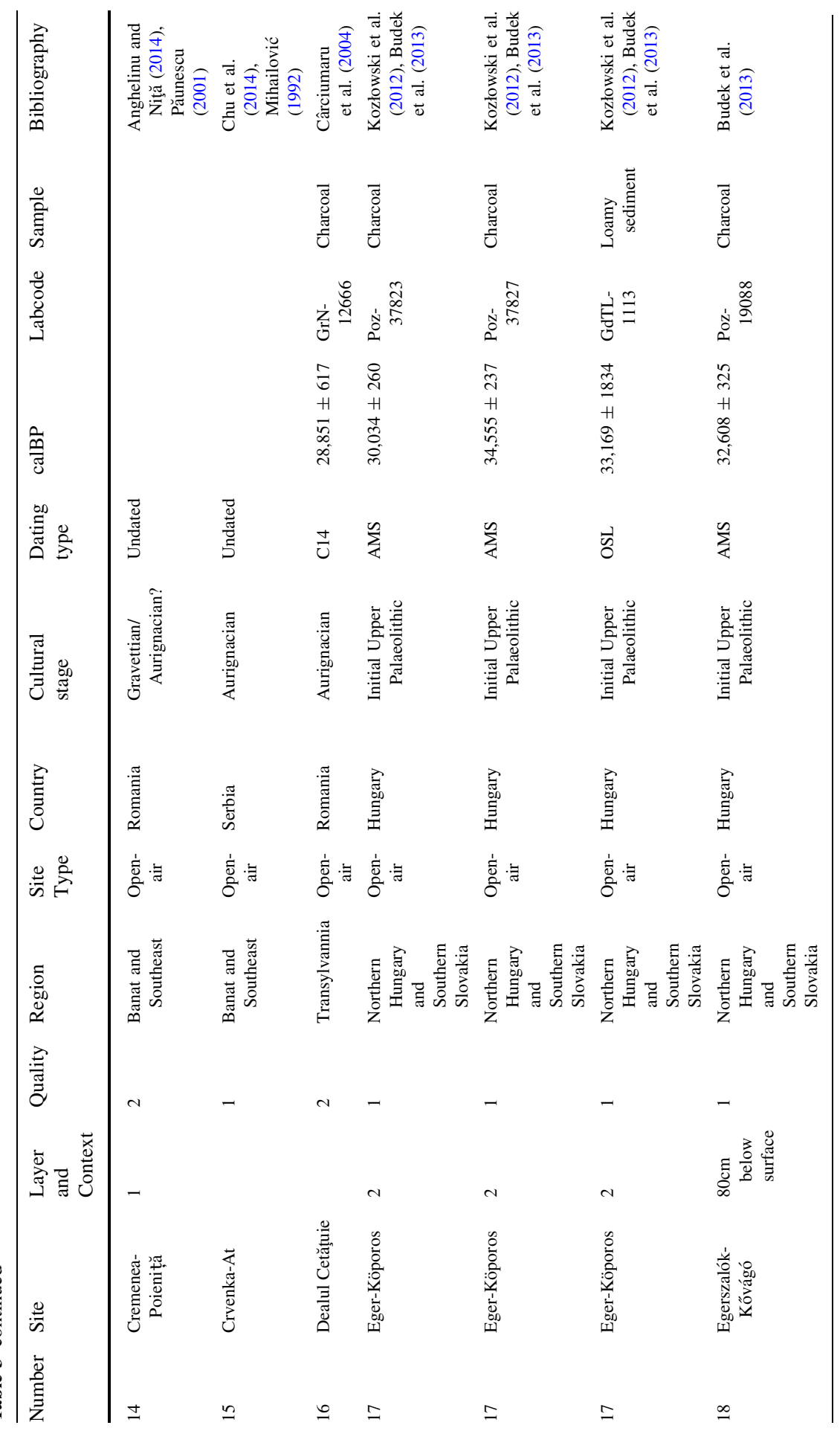




\begin{tabular}{|c|c|c|c|c|c|c|c|}
\hline 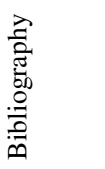 & 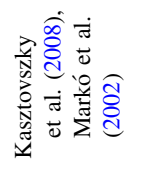 & 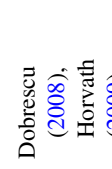 & 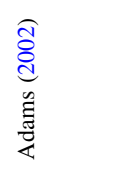 & 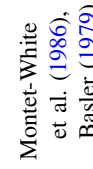 & 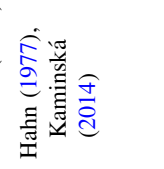 & 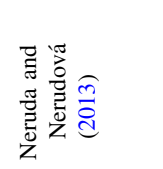 & 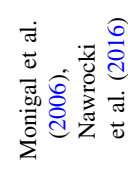 \\
\hline $\begin{array}{l}\frac{0}{2} \\
\text { है } \\
\text { कू }\end{array}$ & & & : & & & 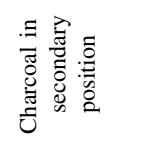 & 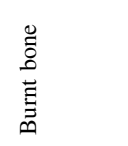 \\
\hline 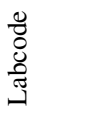 & & & 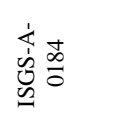 & & 安 & दुछ & $\sum_{0}^{\stackrel{N}{N}}$ \\
\hline 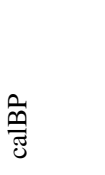 & & & $\begin{array}{l}+ \\
0 \\
\infty \\
H \\
H \\
8 \\
0 \\
0 \\
\dot{m}\end{array}$ & & $\begin{array}{l}\text { ¿ें } \\
\text { H } \\
\text { m } \\
\text { a } \\
\text { mi }\end{array}$ & 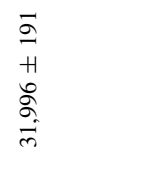 & $\begin{array}{l}\frac{m}{n} \\
+1 \\
\frac{n}{5} \\
\frac{0}{n}\end{array}$ \\
\hline 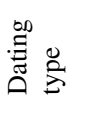 & 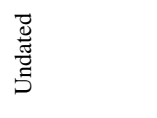 & $\begin{array}{l}\vec{d} \\
\frac{\mathbb{d}}{\tilde{g}} \\
\overrightarrow{5}\end{array}$ & $\sum_{4}^{\infty}$ & $\begin{array}{l}\overrightarrow{0} \\
\frac{0}{\tilde{J}} \\
5 \\
5\end{array}$ & $\sum_{<}^{n}$ & $\sum_{<}^{n}$ & $\vec{U}$ \\
\hline 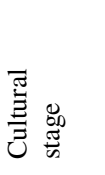 & 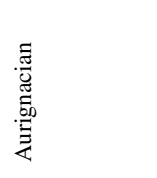 & 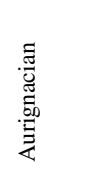 & 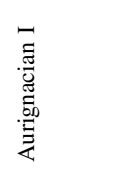 & 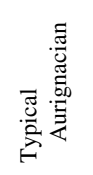 & 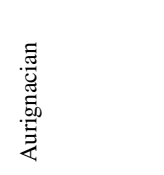 & 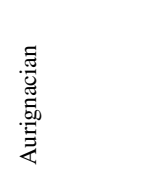 & 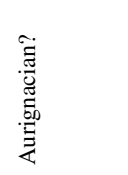 \\
\hline 音 & 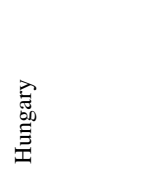 & 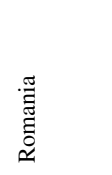 & $\begin{array}{l}\text { 空 } \\
\text { 業 }\end{array}$ & 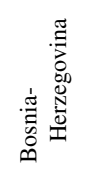 & $\begin{array}{l}\frac{a}{2} \\
\frac{\pi}{\pi} \\
\frac{\partial}{n}\end{array}$ & 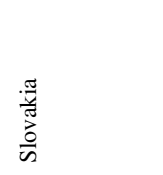 & $\begin{array}{l}\frac{\mathscr{E}}{\pi} \\
\frac{\sqrt{5}}{5}\end{array}$ \\
\hline 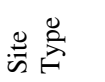 & 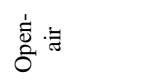 & 产: & $\sum_{\tilde{U}}^{0}$ & 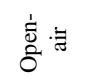 & 㐫: & 言: & 㝘. \\
\hline & 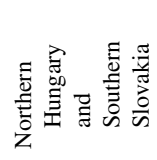 & 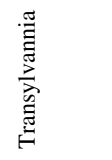 & 慈兽 & 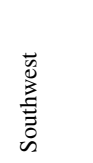 & 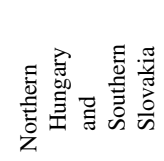 & 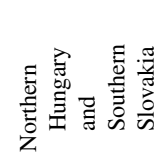 & 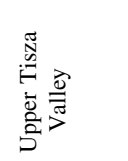 \\
\hline 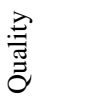 & - & $N$ & - & $\mathrm{N}$ & 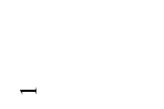 & - & - \\
\hline 离空芯 & & & 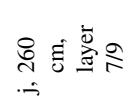 & N & & & $\Xi$ \\
\hline$\stackrel{0}{=}$ & 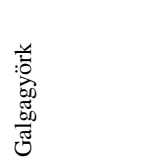 & 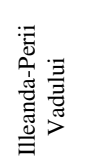 & 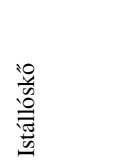 & $\begin{array}{l}\text { ฮี } \\
\text { ฮ్ }\end{array}$ & 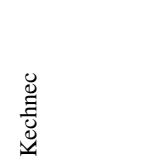 & 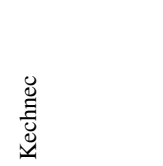 & 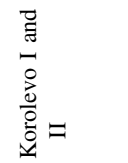 \\
\hline 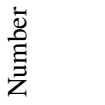 & $\approx$ & ¿ & $\vec{\lambda}$ & ส & $\pi$ & $\pi$ & t \\
\hline
\end{tabular}




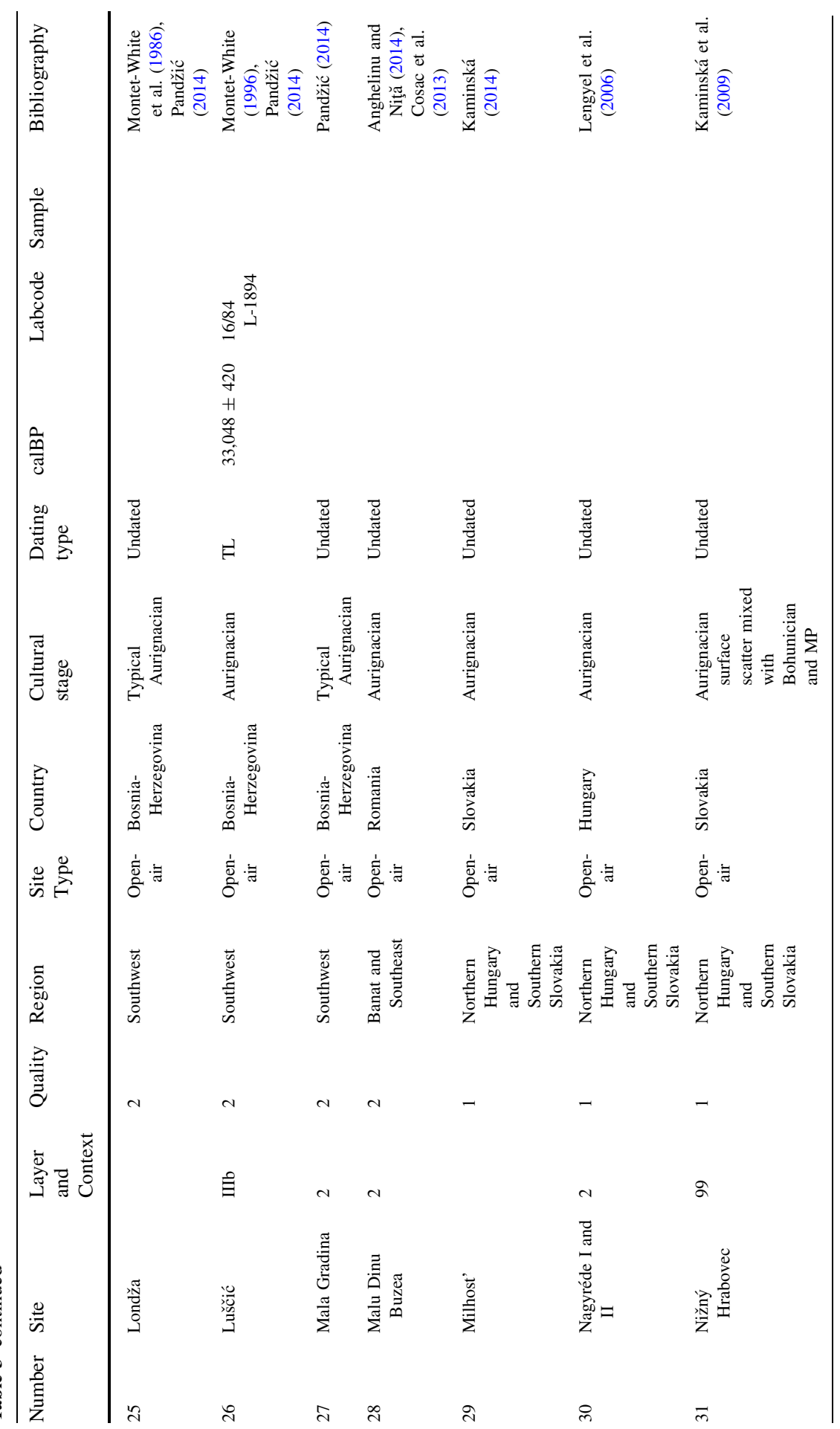




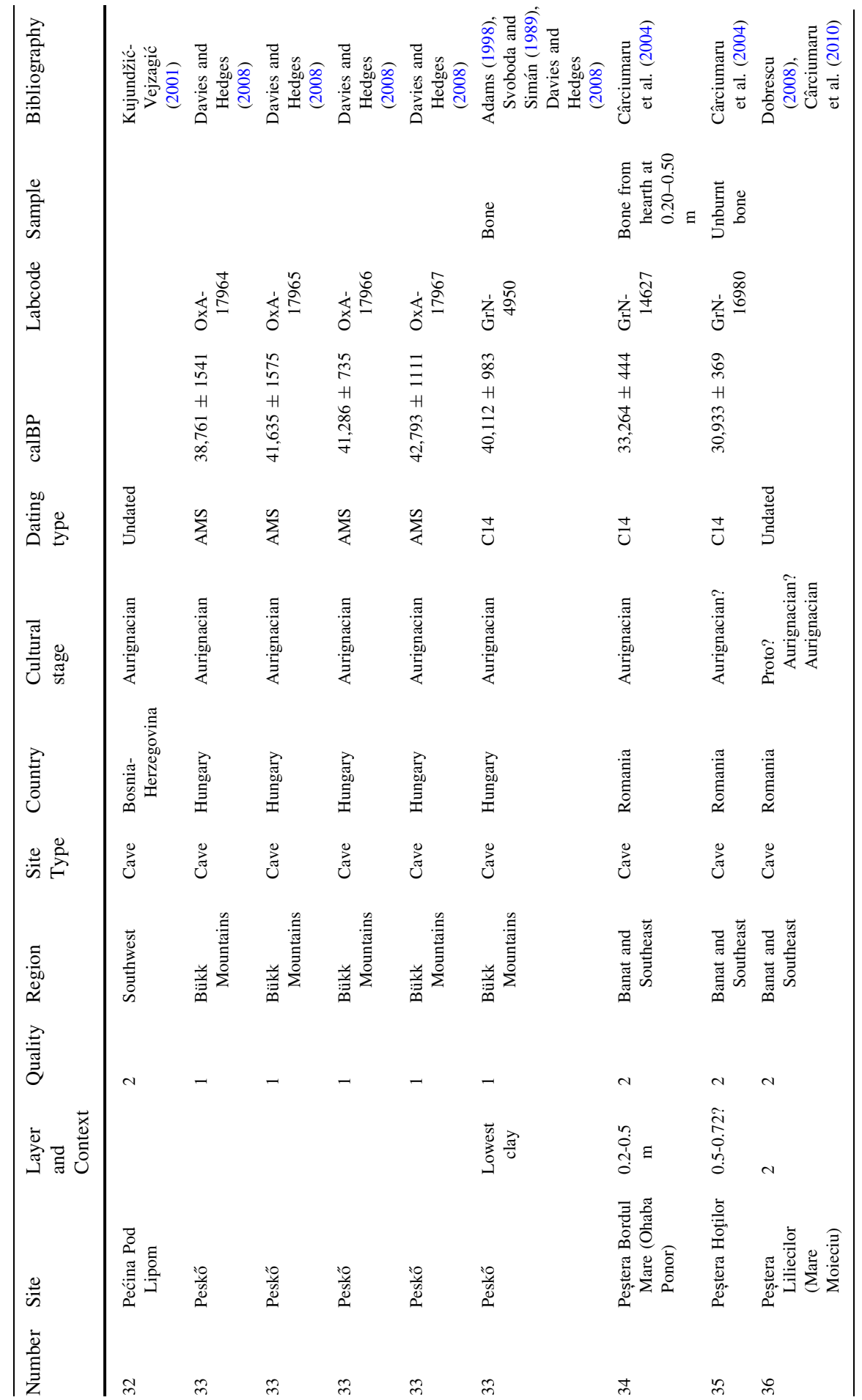




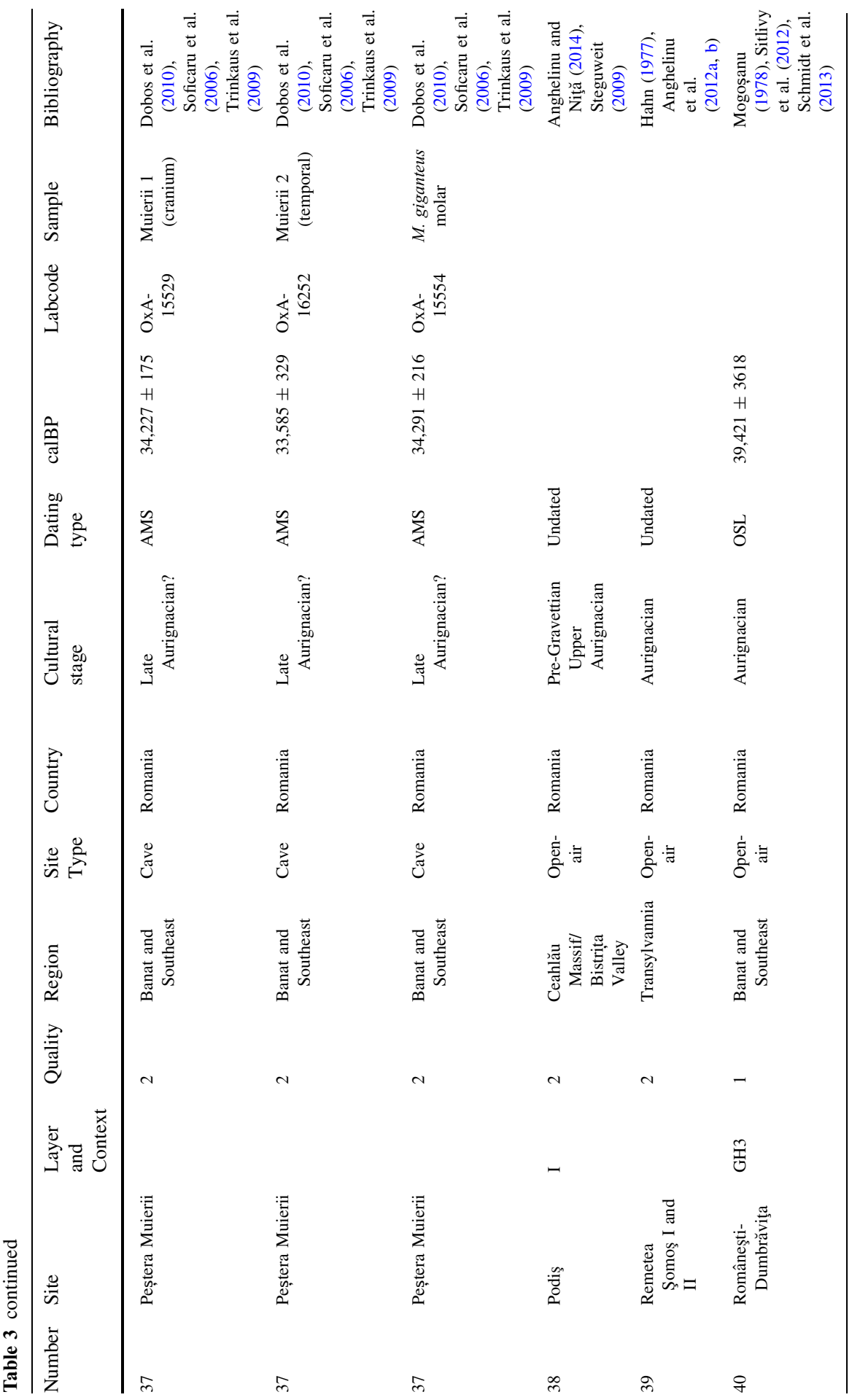




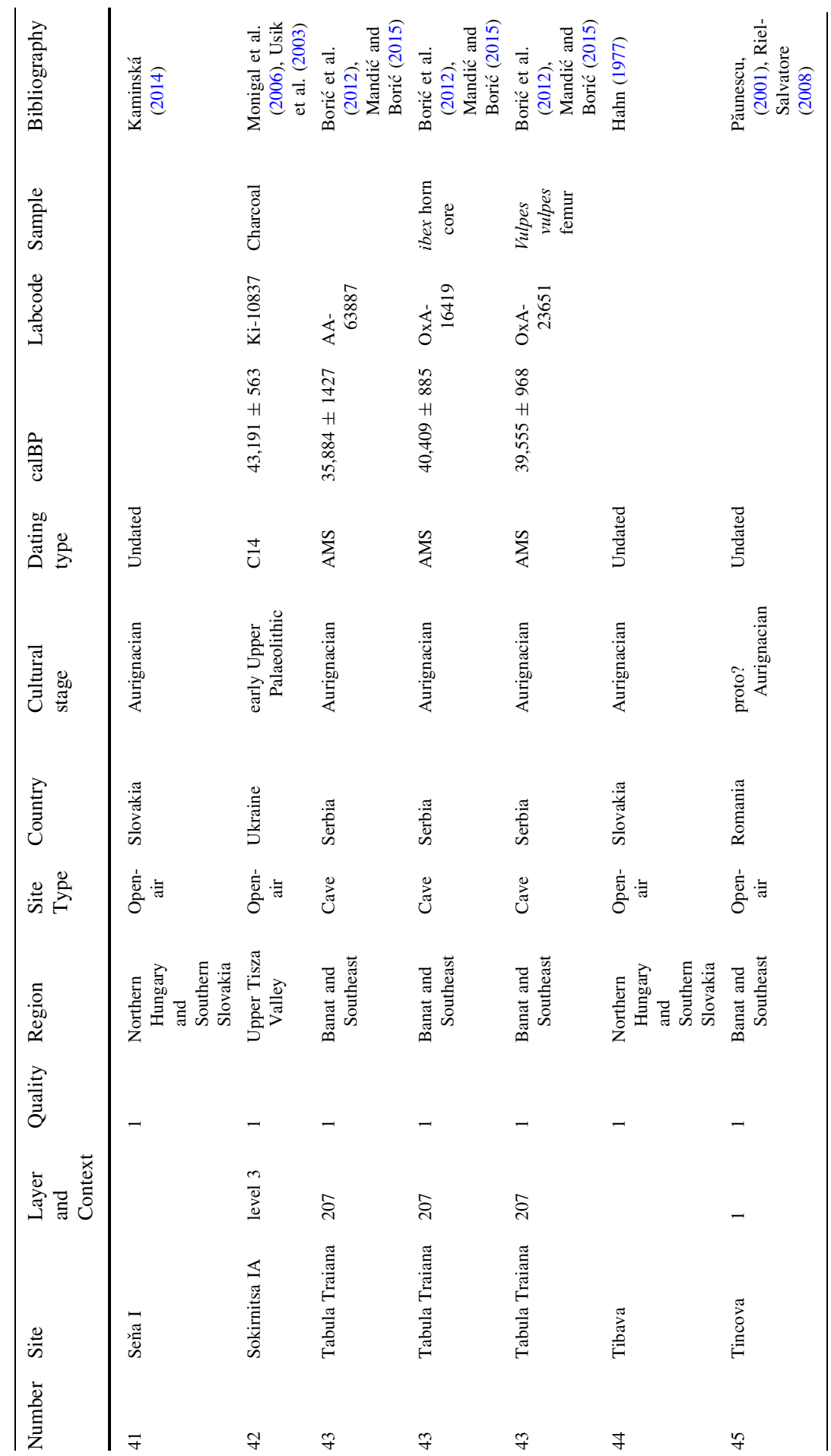




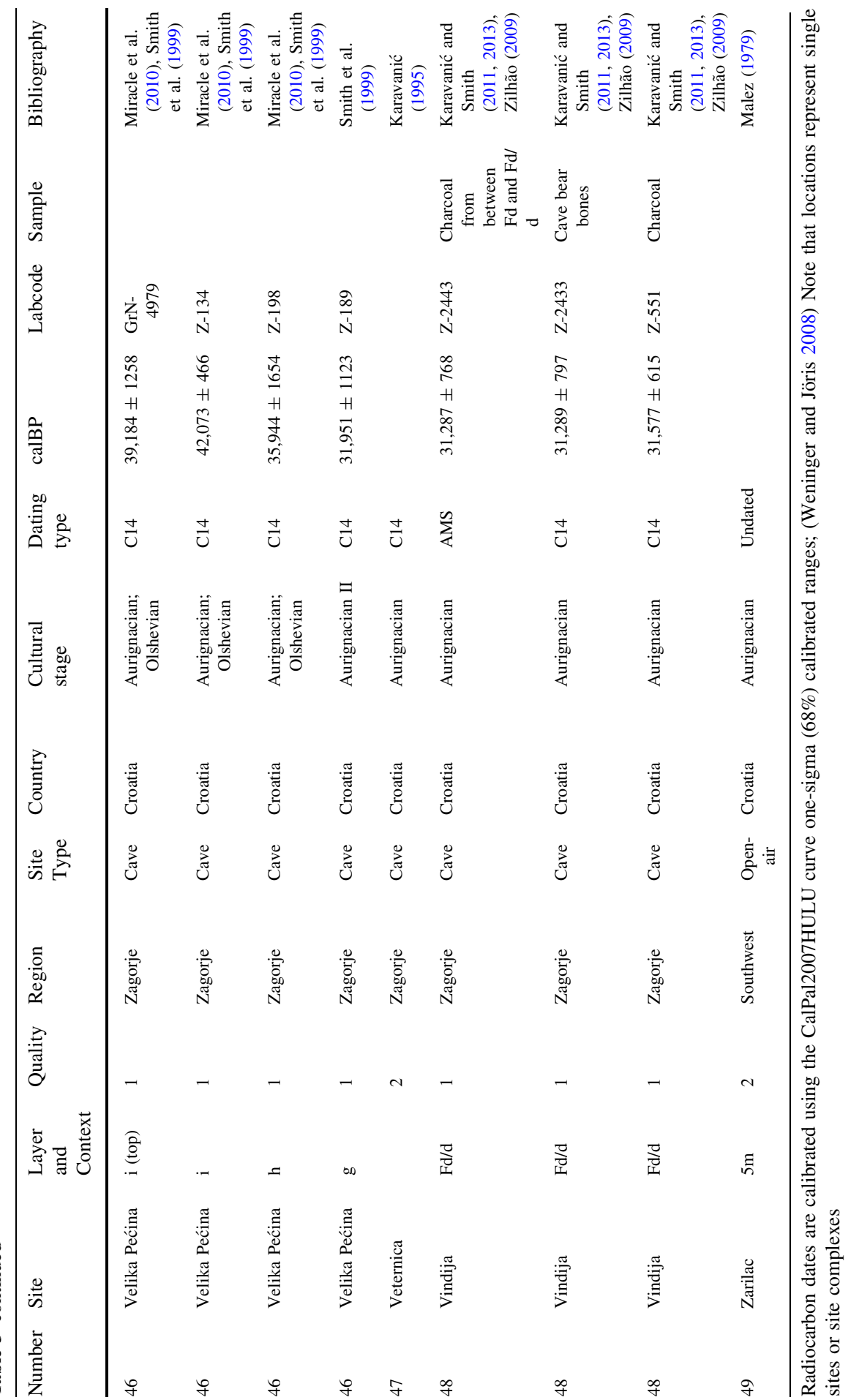



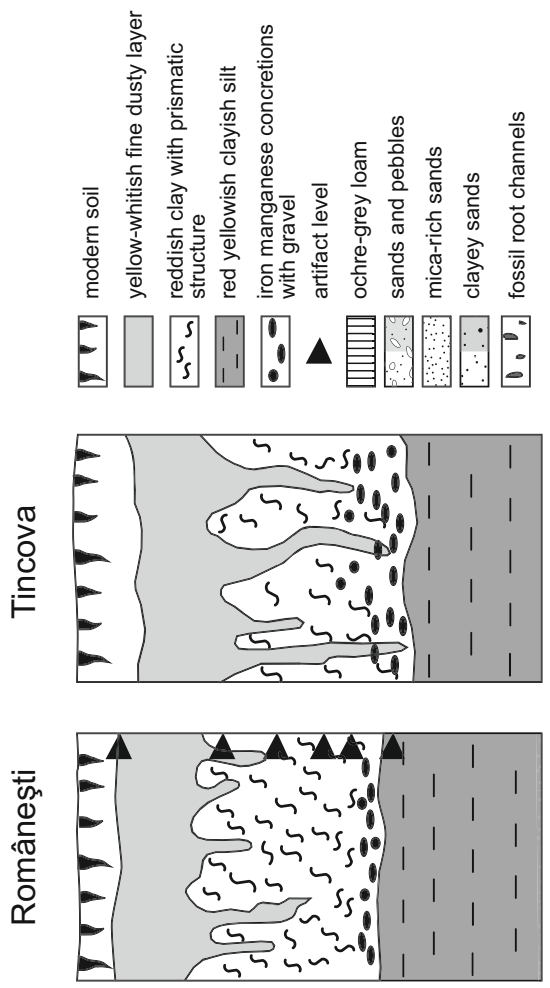

O) 

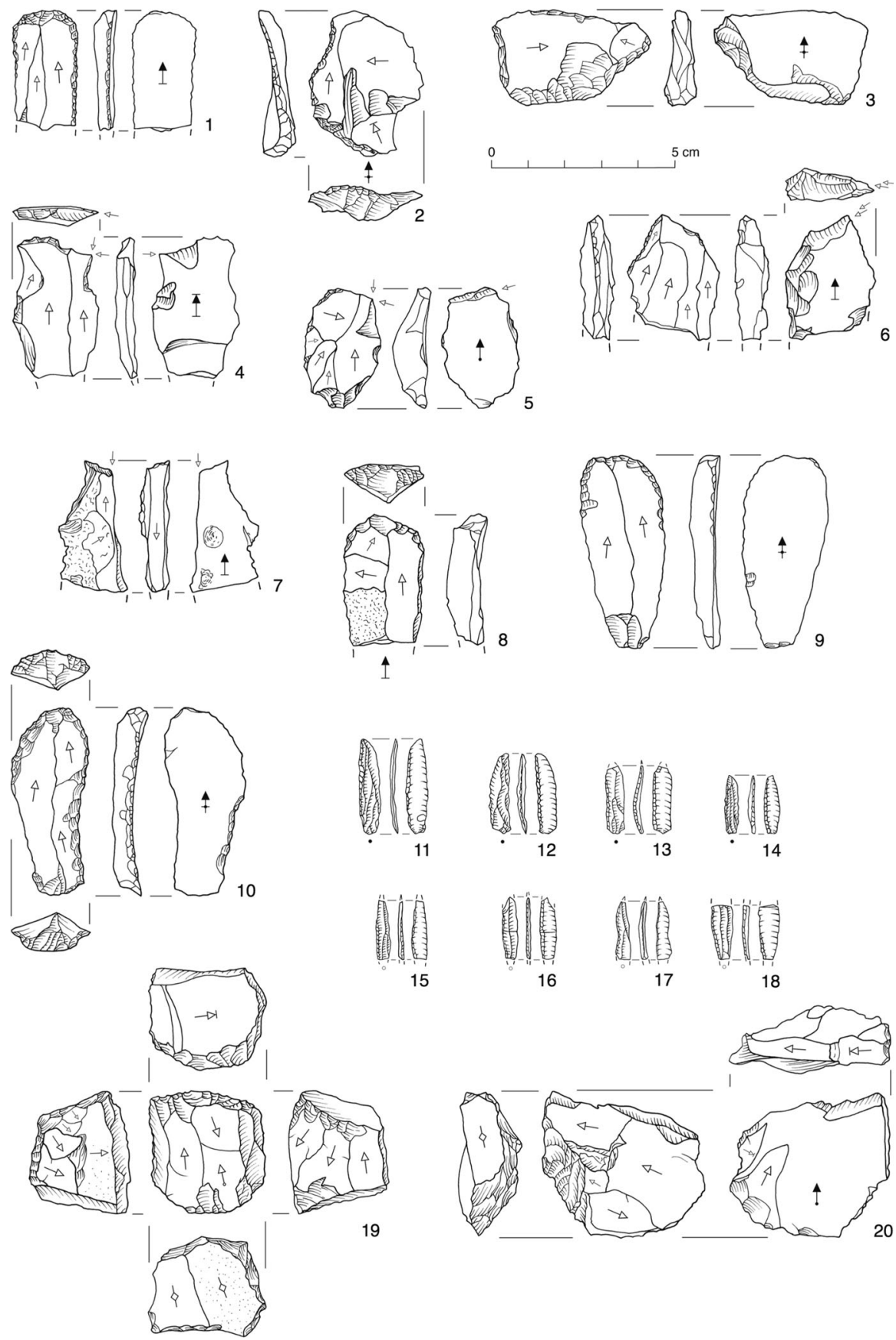

19

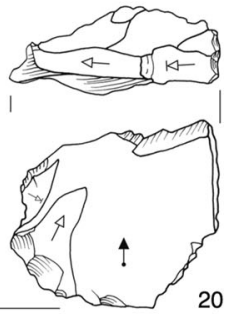

Fig. 3 Aurignacian artifacts from the Românești site 
2012). Additionally, paleoenvironmental reconstructions based on sedimentology and geochemistry of the embedding matrix suggest that the artifacts were deposited during a period when a moderate, humid forest steppe predominated (Kels et al. 2014).

The twin site of Coșava (282 mamsl) is located $4 \mathrm{~km}$ across the Bega Valley. Like Românești, it was the object of two excavations during the 1960s. Based on artifact depth and typology, the original excavator identified two Aurignacian layers superimposed by a final Upper Paleolithic layer (Mogoșanu 1978). These layers and their attributions were later reconfirmed by Sitlivy et al., who again noted the presence of small debitage not present in the earlier collections (Kels et al. 2014; Sitlivy et al. 2014a). This, in addition to sediment analyses, suggests limited postdepositional processes associated with the lithic artifacts (Kels et al. 2014; Sitlivy et al. 2014b). Dating the site has been problematic due to the absence of organic remains and burned artifacts. OSL dates of underlying sediments are anomalously old (61-50 ka BP), possibly due to sediment mixing in the lower archaeological layers.

A third Banat site, Tincova, was first excavated in 1958-1960 (NicolăescuPlopșor and Stratan 1961; Stratan 1962) and later by Mogoșanu and Stratan (19651966; Mogoșanu 1978). Mogoșanu excavated an area of $280 \mathrm{~m}^{2}$ in the knickpoint of a gully, recovering 2494 lithic artifacts. Some 500 of the artifacts are tools, leading to the interpretation that the site was an Aurignacian workshop (Anghelinu et al. 2012a; Păunescu 2000). The high ratio of worked pieces and the low artifact density (c. 9 artifacts $/ \mathrm{m}^{3}$ ) may suggest an excavation bias, though recent research indicates that this may not be the case (Chu, Zeeden, and Petrescu 2016).

Further Aurignacian artifacts were found across the border in the Serbian Banat at Crvenka-At, close to the Peștera cu Oase. The site is represented by at least two localities, Crvenka and At, found $3 \mathrm{~km}$ apart along a channelized river. These artifacts were found opportunistically within sand-extraction pits (Fig. 4) in what is likely a fluvial terrace, suggesting that both Crvenka and At are windows into a larger fluvial occupation zone-a hypothesis confirmed by the numerous Aurignacian artifacts found around the city of Vršac, where archaeological materials have been collected from sand extraction sites since the end of the nineteenth century (Fig. 5; Mihailović 1992, 2011). Attempts to locate in situ finds have since identified at least two archaeological levels (Radovanović 1986). An upper layer, found in a sandy matrix where artifacts are abraded, implies that fluvial activity played a depositional role. A second, deeper layer is found in fine-grained sediments and may indicate a more in situ assemblage. Current work aims to elucidate the precise age and geomorphology of the site; however, it is clear that the collections from Vršac come from a widely-distributed yet dense suite of Aurignacian archaeological sites (Chu et al. 2014; Chu, Mihailović et al. 2016).

In addition to the open-air sites, there are fainter traces of modern humans in the Banat karstic caves. At Tabula Traiana Cave (Serbia), lithic artifacts suggestive of the proto-Aurignacian were found above a Campanian ignimbrite tephra and dated with associated cutmarked bones to between 41.3 and $34.5 \mathrm{ka}$ cal BP (Borić et al. 2012; Mandić and Borić 2015). Still, the assemblage is small $(\mathrm{N}=3)$ and diagnostic artifacts are absent. Nearby, archaic modern human fossils were also reported in 

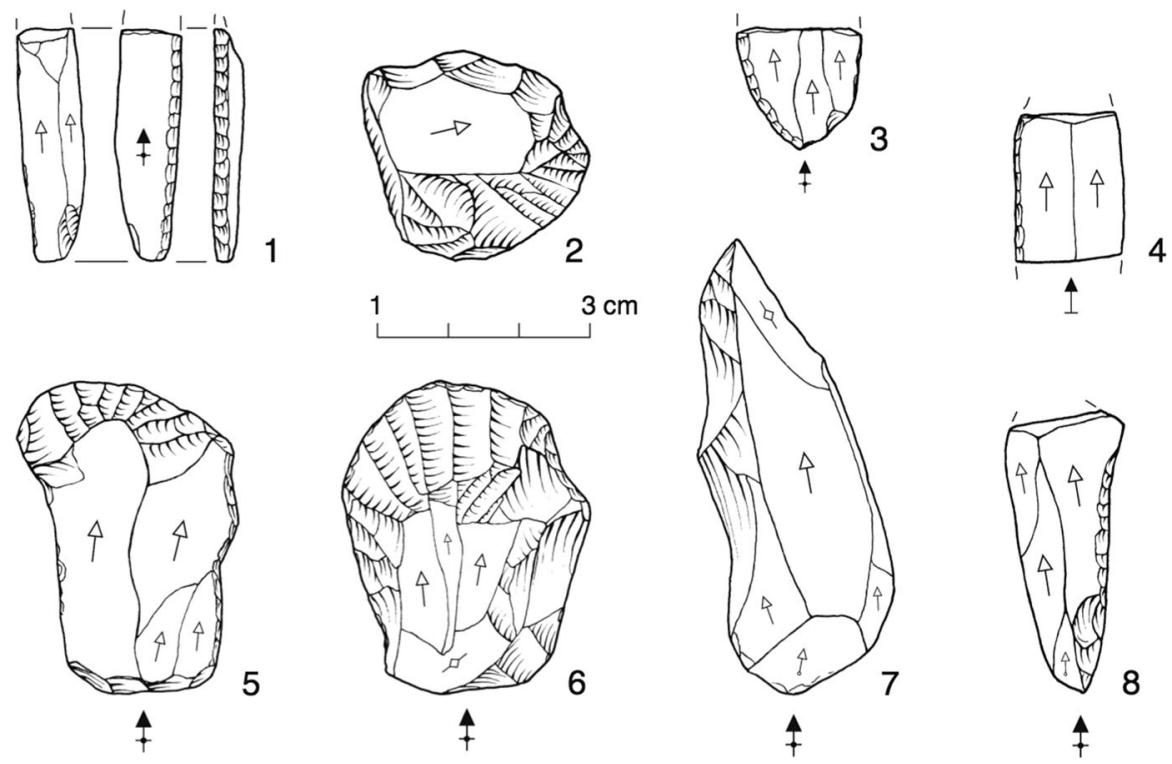

Fig. 4 Early Upper Paleolithic artifacts from At, recovered in situ (Serbia; Chu, Mihailović et al. 2016)

association with Paleolithic artifacts from Bački Petrovac; however, these valuable finds were poorly described and are now lost (Radović et al. 2014).

A stronger candidate for an early Aurignacian in the southeastern Carpathian Basin karstic caves is the Peștera Liliecilor (Dobrescu 2008, p. 409; NicolăescuPlopșor 1957). Excavations indicated a Mousterian layer superimposed by an Aurignacian containing some 173 pieces, of which one-third are tools capped by a Gravettian layer (Cârciumaru et al. 2010, p. 37). Nevertheless, stratigraphies are inconsistent and the provenience of the artifacts remains unclear (Cârciumaru et al. 2010, p. 145).

There are further smaller, insecure Aurignacian findspots in the southeastern Carpathian Basin. At the Peștera Bordul Mare, worked flints $(\mathrm{N}<18)$ and two faunal artifacts overlay a Mousterian layer (Dobrescu 2008, p. 375; Păunescu 2001, p. 296), but it is heavily disturbed with assorted post-Paleolithic material and the radiocarbon dates of 33.7-32.8 ka cal BP cannot be securely linked to the assemblage (Anghelinu and Niță 2014). The collection from Malu Dinu Buzea is composed of massive blades, flakes and small-sized abandoned bladelet-cores with few formal tools (Păunescu 2001, p. 363); however, recent research suggests a taphonomic history that may position the assemblage to the final Upper Paleolithic (Cosac et al. 2015). The site of Gornea has blades and endscrapers, but it remains undated and most of the artifacts suggest that it is probably Middle Paleolithic (Cârciumaru and Anghelinu 2000; Mogoșanu 1978). The situation is similar to the undated Peștera Hoţilor, which shows a modest 15 retouched blade fragments that have also been ascribed to the Aurignacian purely on a typological basis (Anghelinu et al. 2012a). 

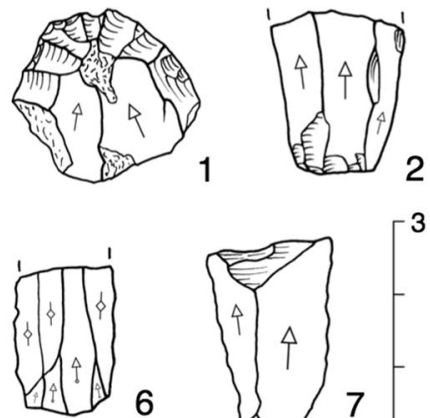

6
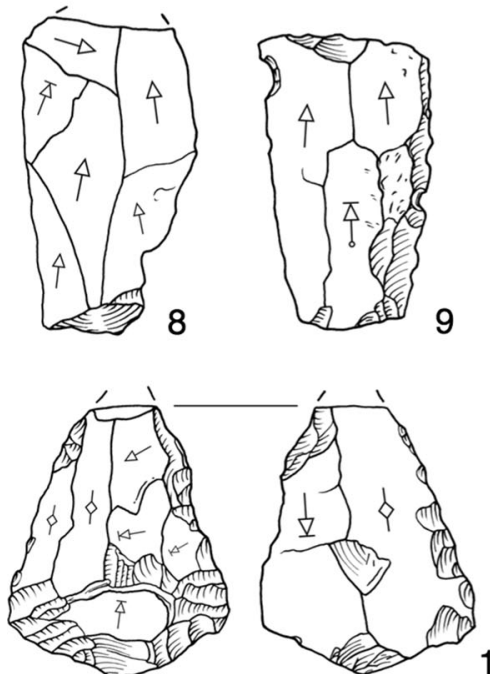

13

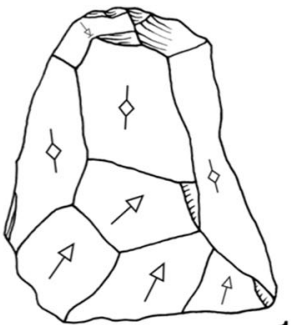

14

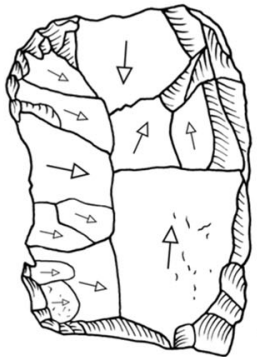

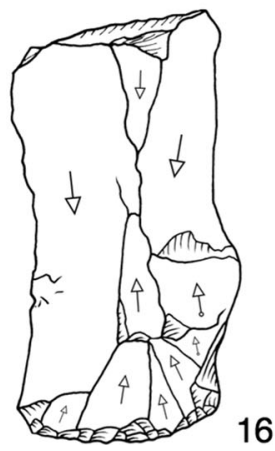
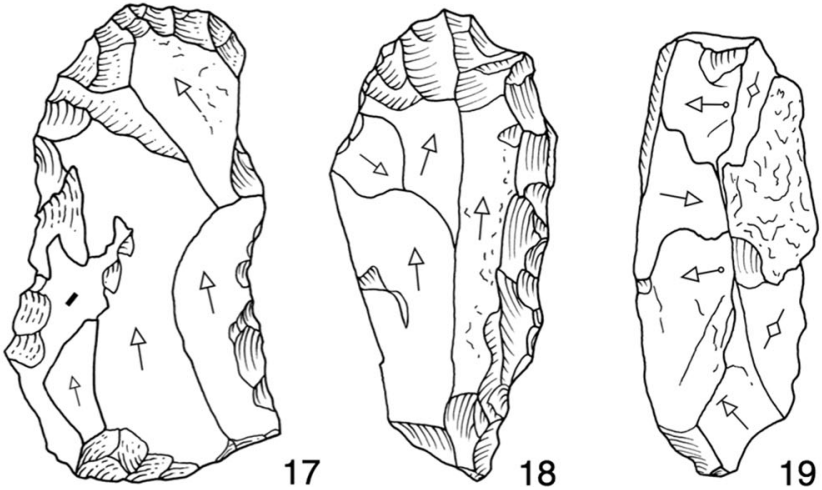

Fig. 5 Aurignacian stone artifacts from the Seňa I site (from Kaminská 2014; after Bánesz 1958) 
By contrast, the caves in the Romanian Banat show indisputable precocious traces of modern humans through their well-dated skeletal remains. Unfortunately, their associations with lithic residues remain either tenuous or absent. At the Peștera cu Oase, human fossils were found deep in a cave chamber with Pleistocene fauna, but unfortunately without lithic artifacts. All surveys and excavations of the cave entrances have failed to yield contemporaneous sediments or lithic residues, possibly as a result of Late Pleistocene climate-driven erosion and/or rockfall.

At the Peștera Muierii, excavated in the early 1950s, archaic modern human remains were later radiocarbon dated to $34 \mathrm{ka}$ cal BP (Alexandrescu et al. 2010; Soficaru et al. 2006). A small number of Aurignacian artifacts ( $N=60-80$; mostly blades and blade fragments) and three bone points were reported from the cave (Păunescu 2000; Soficaru et al. 2006). However, the whereabouts and attribution of these artifacts and their association with the fossils is uncertain, due to their unsystematic recovery during excavation (Doboș et al. 2010, p. 41). Similarly, the early modern human cranium from Peștera Cioclovina (c. $32.5 \mathrm{ka}$ cal BP) was associated with two blades, one flake and Ursus spelaeus vertebrae (Harvati et al. 2007). Further undated artifacts are reported from elsewhere in the cave, though their typological attribution to the Aurignacian is disputed (Anghelinu and Niţă 2014).

In short, the geologically diverse Banat and southeastern Carpathian Basin have many early Aurignacian sites (with, curiously, no apparent 'transitional industries'), in addition to many well-dated, well-attributed modern human remains of coeval early Upper Pleistocene ages. Frustratingly, the two are not found in direct association, with the former located mainly in open-air settings, while the latter is exclusively found in karstic cave environments. It seems evident that a main goal of research in this area is the connection of these two archives.

\section{Ceahlău Massif and Bistrița Valley (Romania)}

In the east of the Carpathian Basin, small Aurignacian assemblages are reported from Ceahlău-Cetățica (I and II), Ceahlău-Dârțu, Ceahlău-Podiș and BistricioaraLutărie, all located along the middle terraces of the Bistrița River that bisects the Eastern Carpathians. However, the scarcity of diagnostic artifacts and an atypically young chronology have cast doubt on the authenticity of the Aurignacian sites (Anghelinu, Niţă, and Steguweit 2012; Steguweit et al. 2009; Trandafir et al. 2015).

Interestingly, there are many well-documented Aurignacian sequences found across the watershed on the other side of the Carpathians (outside of the Carpathian Basin) in the Prut Valley, where continuous sequences have been found at the large sites like Mitoc-Pârâul lui Istrati, Ripiceni-Izvor and Mitoc-Malu Galben that have been well dated to between 37 and 32 ka cal BP (Damblon and Haesaerts 2007; Honea 1990; Otte et al. 2007). Though the connections between these two areas remain vague, some of the raw material in the Bistrița sites appears to have been transported from the Moldavian plateau as well as the Dobruja region, suggesting an early spatial connection across the Carpathians (Crandell, Niță, and Anghelinu 2013). 


\section{Transylvania (Romania)}

There are further finds in the hilly regions of historical Northern Transylvania, near watercourses. Like the eastern Carpathian Basin in Romania, nearly all of the Aurignacian sites provided small or poorly contextualized collections from surface excavations lacking in typical diagnostic artifacts (Dobrescu 2008). The largest archaeological assemblages are from Cremenea. At Poieniță (c. 700 mamsl), tools are mainly manufactured from large blocks, pebbles and plaques of poor quality local flint that only allow for the production of large blades and flakes, complicating a secure attribution to the Aurignacian (Mărgărit and Niță 2005).

In the Oaș-Maramureș regions, recent techno-typological reassessments of Boinești, Remetea Șomoș I \& II, Bușag and Călinești have suggested that there is an Aurignacian component to the assemblages overlaying Mousterian accumulations (Anghelinu and Niță 2014; Dobrescu 2008). However, the sediments may have been reworked, perhaps some time during the Holocene (Tuffreau et al. 2013), making them difficult to date and separate from the Mousterian and Gravettian elements (Dobrescu 2008).

\section{Northern Hungary and Southern Slovakia}

In the north of the Carpathian Basin, there are indicators of an early Upper Paleolithic presence in the North Hungarian Range and adjacent southern Slovakia. Surveys have identified artifact surface scatters on river terraces and in valley culde-sacs of the low foothills of the Bükk, Mátra and Cserhát Mountains (Péntek and Zandler 2013).

In eastern Slovakia, the Aurignacian is well known along the Hornad Valley in the Košice Basin (Hahn 1977; Kaminská 2014). Multiple sites in the villages of Barca, Kechnec, Seňa, Milhost' and Čečejovce have been recognized for their deeply cut ditches (Gräben) often containing stone-lined hearths and artifact concentrations frequently interpreted as subterranean storage units and dwelling structures (Fig. 5; Bárta 1987). Unfortunately, most of these sites were found in short, heavily-eroded sedimentary sequences and, except Barca I and Kechnec, remain largely undated.

At Barca, charcoal yielded a date of $34 \pm .3 \mathrm{ka}$ cal BP, but this is considered a minimum date because of subsequent sediment disturbance by later Neolithic settlements. At Kechnec, two dates from charcoal suggest a later date around 32.1 $\pm .2 \mathrm{ka}$ cal BP; however, neither can be firmly connected to the Aurignacian settlement (Kaminská 2014, p. 156). Perhaps partly as a result of these late dates, the Košice Basin sites are frequently designated as an iteration of the 'Evolved Aurignacian' industry (Svoboda 2006).

There are also reported concentrations farther east in Slovakia, notably at Tibava, that also contain ditches, stone-lined hearths and Aurignacian lithics $(\mathrm{N}=866)$ similar to the Košice Basin sites (Bánesz 1960). Additionally, over one thousand artifacts, predominantly flakes and blades and a few dozen tools manufactured predominantly on local limnosilicite (i.e. limnoquartzite), were recovered from the 
areas of Nižný Hrabovec (I and II) and Poša that may be, but cannot be securely demonstrated to be, late MIS 3 in age (Kaminská et al. 2000).

Though conspicuously absent on the other side of the Hornad Valley in Hungary, early Upper Paleolithic artifacts have been recovered around the city of Eger on the southwestern edges of the Bükk Mountains. The most well-known, Eger Köporos, is interpreted as a palimpsest of late Middle Paleolithic, an early macroblade industry, a Late Szeletian and a possible Aurignacian (Dobosi 1995; Mester 2000). The site remains woefully unstratified but micromorphology, sedimentology, OSL and radiocarbon dating suggest that the artifact-bearing colluvia formed some $25 \mathrm{ka}$ ago, indicating that the assemblages are at least that old (Dobosi 1995; Kozłowski et al. 2012).

Since the 1970s, surface finds have been collected from the nearby site of Egerszalók-Kővágó, located on a low-lying hill in the foreground of the Bükk Mountains. Later systematic excavations recovered artifacts but were unable to find stratified layers due to possible erosion. Based on techno-typology and raw material types, artifacts were found to belong to four different industries: Szeletian, Initial Upper Paleolithic, Aurignacian and a potential Gravettian (Kozłowski et al. 2009). If compared to other dated regional assemblages, the Initial Upper Paleolithic assemblage may date to between 40 and $35 \mathrm{ka}$ ago, and the Aurignacian to between 35 and 28 ka ago (Budek et al. 2013; Kozłowski et al. 2009), though without cosmogenic dating, these dates and attributions can only be seen as tentative.

Two other surface sites in the Eger region, Andornaktálya-Zúgó and Gyilkos Hill are attributed to the Late Aurignacian culture, based on their techno-typological characteristics. However, these tools are atypical, as they are dominated by endscrapers on flakes and there are Middle Paleolithic sidescrapers present (Budek et al. 2013; Kozłowski et al. 2009).

There are further finds in the foothills of the Cserhát section of the North Hungarian Range. At Acsa-Rovnya, excavations in 2001-2004 yielded over 500 artifacts, notable for many endscrapers on blades (Dobosi 2008, 2013). Many locales in nearby Galgagyörk have also yielded alleged Aurignacian finds that have been typologically separated from the background palimpsest, though they are few and always made on lower quality Szeletian felsitic porphyry (Kasztovszky et al. 2008; Markó et al. 2002).

The strongest case for an Aurignacian in northern Hungary is found in the Mátra Mountains and includes the surface scatters at Nagyréde I and II, where approximately 2000 lithic artifacts were found, primarily manufactured on local hydroquartzites (Lengyel et al. 2006). All of the recovered artifacts were surface finds and attempts to recover in situ sediments were unsuccessful. However, most of the tools are endscrapers, with no indication of earlier or later technocomplexes, suggesting that the sites may represent discrete Aurignacian assemblages (Fig. 6).

The Northern Carpathian record has numerous early Upper Paleolithic findspots and assemblages that are often confounded by regionally specific industries or erosional palimpsests and are largely without stratigraphic and/or radiometricallydated context. Nevertheless, from a typological viewpoint, the Aurignacian record is undeniable, even though open-air sites have been largely neglected, possibly as a result of regional focus on the more famous cave sites in the Bükk Mountains. In 

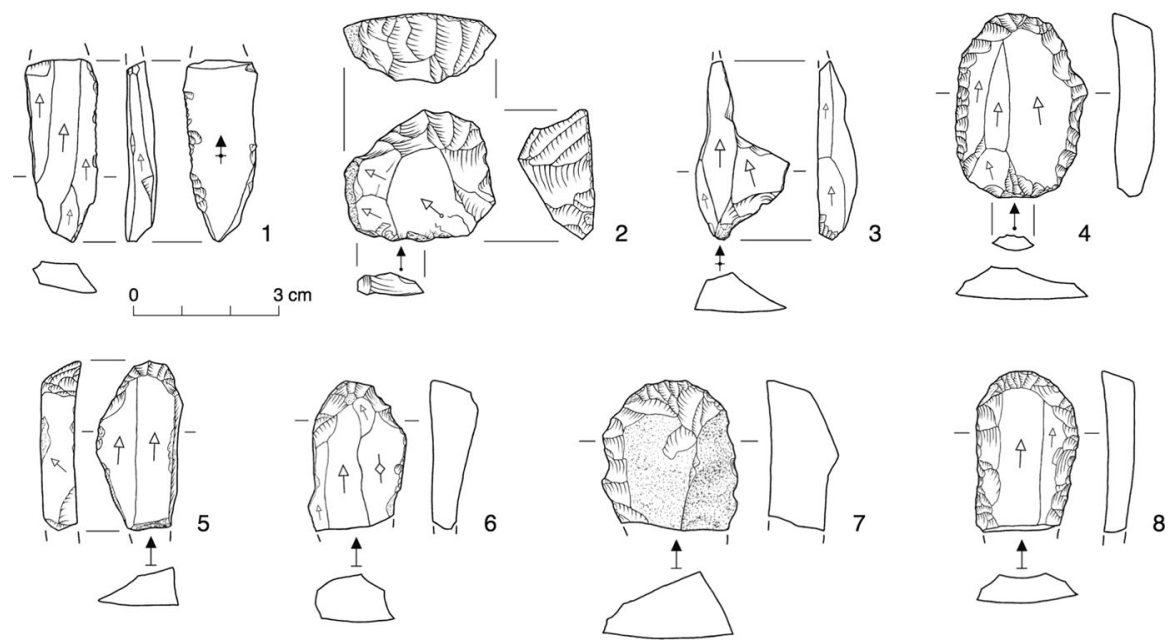

Fig. 6 Aurignacian artifacts of the Nagyréde 1 and 2 assemblages

areas where loess is still well preserved and undisturbed by agriculture, the archaeological potential has clearly not been fully exploited (Chu et al. 2007).

\section{Upper Tisza Valley (Ukraine)}

Further dated early Upper Paleolithic collections have been identified in the small hills of the Transcarpathian lowlands (<400 mamsl) of Ukraine, in the Upper Tisza Valley at the large open-air sites of Korolevo (I level Ia and II level II), Beregovo I and II and Sokirnitsa I (level 3).

At Korolevo I, excavations since 1974 have found up to 14 cultural layers straddling the Lower to Upper Paleolithic (Koulakovska et al. 2009). Palynological, geological and TL dates of level Ia suggest that deposition took place during a cold phase between 39 and $37.5 \mathrm{ka}$ ago, and paleomagnetics suggest a broader, yet overlapping range of 40-30 ka ago (Monigal et al. 2006). However, recent radiocarbon dating from below the base of the paleosol find level (Ia) indicated an age of $30.7 \pm .513 \mathrm{ka}$ cal BP, suggesting these dates may be overestimated (Nawrocki et al. 2016). Nonetheless, while the dates are within the range of the early Upper Paleolithic and the technology clearly focuses on the production of blades, the absence of diagnostic tools makes it difficult to ascribe the assemblages to the Aurignacian (Fig. 7).

Based on stratigraphic position and a single radiocarbon date (43.8-42.1 ka ago), Korolevo II level II is believed to be slightly older than Korolevo I level Ia. The assemblage contains equal numbers of Middle and Upper Paleolithic tools, leading to disagreement as to whether the assemblage should be techno-typologically ascribed to the Szeletian or the Bohunician (Anikovich 1992; Kozlowski 2000; Monigal et al. 2006). While the assemblage undoubtedly has an Upper Paleolithic 

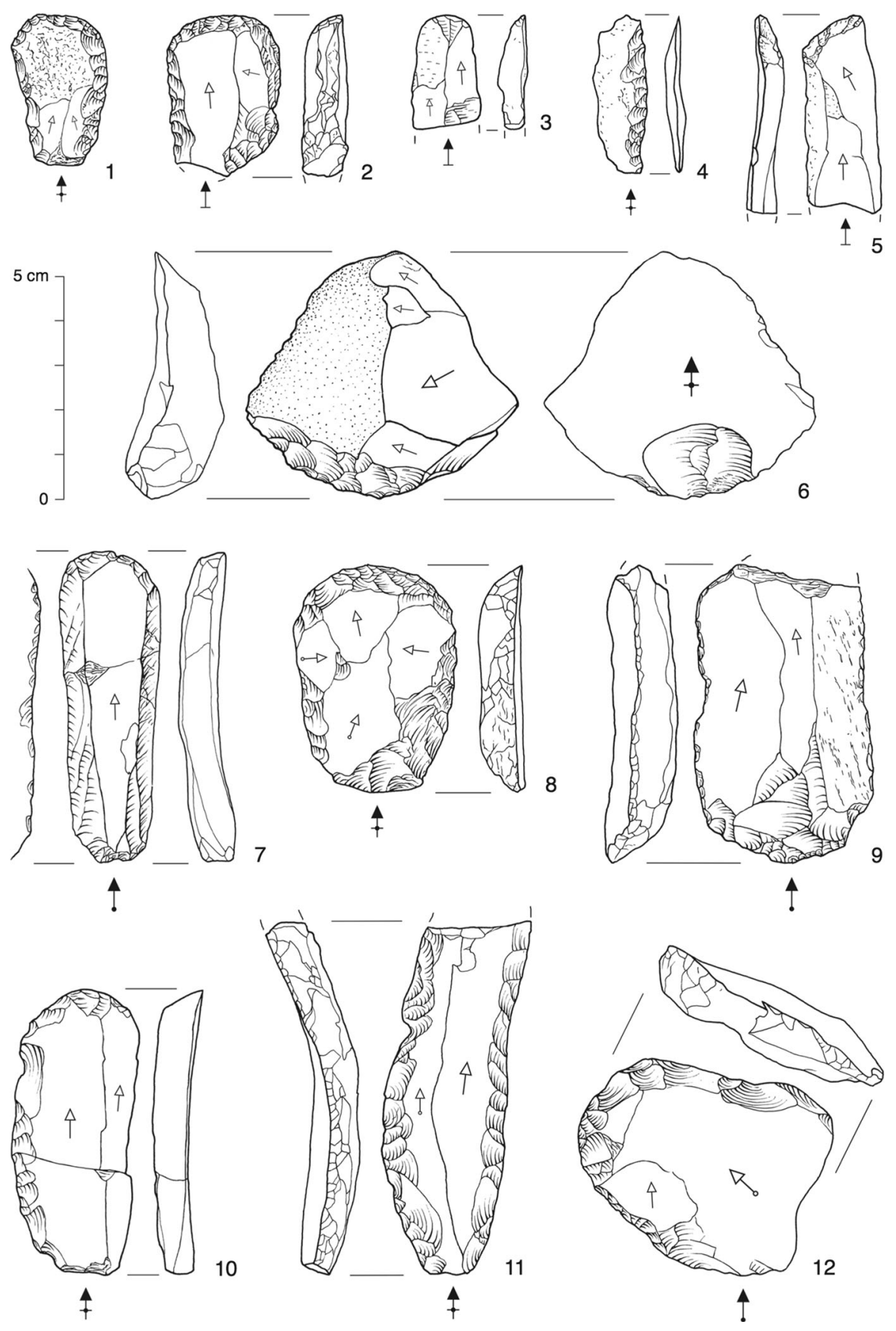

Fig. 7 Korolevo I/level 1a: tools (after Monigal et al. 2006) 
with blade production component, there are no typical Aurignacian tools in the assemblage.

Large early Upper Paleolithic assemblages made from chert, quartz and andesite were also found at Beregovo (I and II) in sands and gravels along ridges near the Tisza River (Usik et al. 2006). The site has been excavated intermittently since the 1960s and recent work has focused on clarifying the chronostratigraphy, taphonomy and human behavior of the site (Usik 2008). New research at Beregovo I, as part of the Upper Tisza Valley Project, has suggested a proto-Aurignacian assemblage with an early Upper Paleolithic age (Usik et al. 2013).

Additional assemblages were found at Sokirnitsa IA during limestone extraction. The main cultural level (level 3) is found below a paleosol at a depth of 80-90 cm within a horizon superimposing at least three discrete Middle Paleolithic horizons. It contains a fully Upper Paleolithic blade industry, though the absence of typical Aurignacian forms makes it difficult to make a formal attribution (Monigal et al. 2006; Usik et al. 2003). Level 3 artifacts were manufactured on local quartzite and slate; however, some flint, chalcedony and andesite are believed to be semi-local, possibly imported downstream from Korolevo. No faunal remains were recovered, though a series of radiocarbon dates on charcoal fragments indicates a date of 43.2 $\pm .5 \mathrm{ka}$ cal BP (Ki-10837; Usik et al. 2003).

In the Upper Tisza Valley, early Upper Paleolithic assemblages are preserved in well-stratified sequences. The dates and lithics point to assemblages that are clearly early Upper Paleolithic in age. However, except for the ongoing work at Beregovo I, researchers have been hesitant to ascribe them to the Aurignacian, and it remains unclear to what extent these sites are techno-typologically connected to other sites in the Carpathian Basin. Currently, these sites are seen as a local, short-lived tradition, though more transnational comparative studies may help to contextualize them within the broader region.

\section{Southwest (Bosnia and Herzegovina)}

Systematic archaeological research in the southwestern Carpathian Basin has been underdeveloped and there have been few systematic surveys, excavations or technotypological studies of sites and assemblages. The known sites are located in the northern foothills of the Dinaric Alpine karst in the Sava River catchment. Stratified sites in this region are virtually unknown and assemblages are usually small and reworked, making it difficult to provenance and accurately identify them technotypologically (Montet-White 1994; Montet-White et al. 1986). The potential for bone preservation is also low, making it difficult to contextualize and date lithic assemblages (Karavanic 1995). Still, limited early Upper Paleolithic artifacts have been found in the northern region of Bosnia in open-air loam and/or eolian deposits along the Sava and its tributaries (Basler 1979; Montet-White et al. 1986).

Recent work in northern Bosnia has focused on field surveying for new sites and re-evaluating pre-existing site validities through small, targeted excavations. Although most of the effort seems to have been dedicated to excavations at Rastuša Cave, which failed to yield any Aurignacian assemblages (Jovanović et al. 2014), there have also been excavations at the multi-layered site of Kamen, where a 
few recovered early Upper Paleolithic artifacts were deemed to be in secondary position (Pandžić 2014).

Excavations at the stratified site of Lušcić, from the 1950s to 1980s, yielded a single Aurignacian layer with carinated pieces and blades from the Urinka Valley. However, given that there were only 17 retouched tools and TL dates provided an unusually young date (29-27 ka ago), this assemblage can only be seen as tentative (Marriner et al. 2011; Montet-White et al. 1986). At Londža, Aurignacian artifacts were similarly found within a $30 \mathrm{~cm}$-thick deposit, possibly indicating longer-term occupation. At the cave site of Pecina Pod Lipom, there is a known stratified layer of later Aurignacian on elongated blades with various tools. However, as of yet, there has been no techno-typological analysis of the site and it remains undated (Kujundžić-Vejzagić 2001).

Northeast of these sites in western Slavonia (Croatia), a small collection of blades and lithics alongside Pleistocene fauna was reported from Zarilac by M. Malez (1979, p. 275). Nevertheless, the lack of systematic excavation of the site, as well as the presence of Neolithic artifacts, suggests that the site may have been heavily reworked. Additionally, the lithics have few, if any, Aurignacian characteristics and are probably mixed with later prehistoric assemblages (Malez 1979; Paunović et al. 2001; Vukosavljevic pers. comm.).

At present, the southwestern Carpathian Basin shows little evidence for an early Upper Paleolithic, with known assemblages being both small and poorly contextualized. Nevertheless, it seems likely that this apparent absence is in part due to low research intensity.

\section{Croatian Zagorje}

One of the best-known Paleolithic regions in the Carpathian Basin is at its western end in the karstic caves of the Zagorje in northern Croatia, near the Slovenian border (Karavanić and Janković 2006; Paunović et al. 2001). The importance of the caves has been recognized since the work of Gorjanović-Kramberger; most recently, they have been exalted for their Neanderthal skeletal remains and the DNA and isotope data that have been extracted from them. In spite of the region's prehistoric importance, only two of these sites have contributed modest early Upper Paleolithic collections (Karavanić 1998).

Vindija Cave is a large cave excavated in the second half of the twentieth century, first by S. Vuković and later M. Malez (Karavanić 1998). This site is best known for Layer G1, where late Neanderthal fossils were found associated with early Upper Paleolithic artifacts (Janković et al. 2006; Karavanić 1995). Layer G1 is sometimes attributed to the Aurignacian on the basis of four bone points and a handful of Aurignacian tools. However, the authenticity of the artifacts and the level of mixing is still debated (Karavanić et al. 2016; Karavanić and Patou-Mathis 2009) and the lithic collection has also been suggested to be either Mousterian, Szeletian or Olschewian (Karavanić and Smith 2011, 2013; Zilhão 2009). To complicate matters further, there are conflicting radiocarbon dates from this level that place the layer anywhere between 39 and $32 \mathrm{ka}$ cal BP (see Ahern et al. 2004; Higham et al. 2006; Smith et al. 1999). Whatever the outcome of these debates, the bone points 
and the few Aurignacian artifacts indicate that Vindija is a possible early Aurignacian site in the Carpathian Basin.

Malez also conducted excavations at the nearby cave of Velika Pećina, the last one ending in 1970 (Karavanić 1998). A 12 m sequence of Quaternary sediments was found: two Middle Paleolithic layers superimposed by five Upper Paleolithic layers. The lowest Upper Paleolithic layer (i) dates to approximately 42-38 ka cal BP based on radiocarbon dates; although an errant 6 ka cal BP old hominin cranial fragment from the Upper Paleolithic layers suggests that there may have been some mixing between the lower and the upper layers (Smith et al. 1999).

In spite of the Neanderthal fossils and associated Middle Paleolithic artifacts, aside from bone points, there is little lithic evidence of an Aurignacian presence in the Zagorje. Moreover, there are other caves in the area which, while rich in late Middle Paleolithic stone artifacts, contain no reported traces of Aurignacian assemblages (e.g. Krapina, Veternica). This absence is augmented by the lack of open-air sites in the surrounding region, suggesting that while the early Upper Paleolithic may have been present, the caves were only expediently used.

\section{The Bükk Mountains (Hungary)}

Another well-known karstic cave region within the Carpathian Basin is the limestone Bükk Mountains of Northern Hungary, where the recent reinvestigations of Szeleta (Adams 2002; Davies and Hedges 2008; Hauck et al. 2016) and Istállóskô caves (Adams 2002; Markó 2015) have brought the early Aurignacian and transitional assemblages back into focus. Research in the archaeology of the Bükk Mountains Late Pleistocene has focused on clarifying the chronology of the Szeletian and its relationship to the Neanderthals and modern humans in Eastern Europe through radiocarbon dating and tephra-chronologies (Davies et al. 2015).

In addition to the Szeletian industries, the Bükk Mountains have also yielded possible Aurignacian assemblages, the most famous being from Szeleta Cave itself. Though excavations have taken place at Szeleta since the beginning of the twentieth century (Mester 2002, 2014; Simán 1995), stratigraphic and absolute dating inconsistencies contribute to the uncertainties over the validity and age of the Aurignacian in Hungary (Svoboda and Simán 1989; Simán 1995; Ringer 2002; Lengyel and Mester 2008; Adams 2009). Due to the alleged presence of leaf-points throughout the excavated sequence and erroneous dating results, the Szeletian and Aurignacian of Szeleta Cave were seen as synchronous cultural complexes between 30 and 20 ka cal BP (Adams 2009; Adams and Ringer 2004). This view contradicted earlier dating results and geochronological estimations that placed the onset of the Szeletian between 46 and 37 ka cal BP (Geyh et al. 1969; Vogel and Waterbolk 1972). Recent attempts at clarifying the chronology from Szeleta failed due to a lack of datable ${ }^{14} \mathrm{C}$ (Davies and Hedges 2008).

Additionally, a recent reanalysis of the lithic assemblages at Istállóskő suggests that Aurignacian lithic artifacts were largely absent in the lower Aurignacian I layer, except for some atypical fragmented blades and a bifacial tool. In the upper Aurignacian II layer, the few Mladec/Olschewa-type osseous artifacts were 
associated with Gravettian flints, Middle Paleolithic tools and bifacial elements (Markó 2015).

Further traces can be found a few kilometers south of Istállóskő at Peskő Cave in the western Bükk Mountains, at an elevation of 745 mamsl. The Peskó assemblage was originally designated later Aurignacian, based on similarities to Istállóskő (Adams 1998, p. 15; Svoboda and Simán 1989). The lithic assemblage at Peskő is small $(\mathrm{N}=27)$, but it is supplemented by four associated bone artifacts, one of which has been dated to c. 42-40.5 ka cal BP (Davies and Hedges 2008).

The Bükk Mountains have also produced two possible early modern humans, but these are poorly understood due to crude excavation techniques and radiocarbon contamination issues (Lengyel and Mester 2008; Neruda and Nerudova 2013). At Istállóskő, a lower right second molar of a juvenile was found in one of the hearths in the lowest Aurignacian layer (Vértes 1955) that was dated to $34 \mathrm{ka}$ cal BP on associated antler points (Davies and Hedges 2008), but it is unclear if the tooth can be ascribed to modern humans (Malán 1955; Tillier et al. 2006). Of similar age but lacking archaeological context is the modern human occipital bone from Görömböly-Tapolca (30.3 \pm .3 ka cal BP; Davies and Hedges 2008; Thoma and Vértes 1975). These two finds indicate that modern humans were present in the Bükk Mountains at least c. $35 \mathrm{ka}$ cal BP. However, considering the earliest dates for the Aurignacian at Peskő Cave, it is possible that modern humans were already present in the region $7 \mathrm{ka}$ earlier.

Like the cave sites in the Croatian Zagorje, the Bükk Mountain sites have long, stratified sequences that have nonetheless created controversy as to the technotypological succession of the Middle to early Upper Paleolithic. What is becoming increasingly clear is that, regardless of the outcome of debates surrounding chronology and industries, the Aurignacian seems to be (aside from the few bone artifacts) absent or at least thinly distributed and poorly contextualized. This is directly in contrast to the open-air assemblages from the Slovakian-Hungarian border regions, which testify to a stronger Aurignacian presence, even if they are not well dated.

\section{Raw Material Economy}

Carpathian orogeny has provided the Carpathian Basin with abundant, easily accessible igneous, metamorphic and sedimentary rocks and minerals that potentially enable the spatial and landscape behaviors of the early Upper Paleolithic archaeological record to be explored in considerable depth. However, while there is a long history of research in the region, there are still significant gaps in identifying and sourcing raw materials, even in the best-understood areas (Biró 2009). Still, among the open-air sites, the raw material evidence is strongly suggestive of locally-focused activities with sites located close to or at raw material sources (Table 4).

At the Banat sites (Românești, Coșava, Tincova and Crvenka-At), lithics are primarily manufactured from a variable quality 'Banat flint.' Petrochemical analyses indicate a local/meso-local source, possibly in the surrounding highlands 
Table 4 Early Upper Paleolithic raw material types used in the CB and their sources and estimated transport distances

\begin{tabular}{|c|c|c|c|}
\hline Site & $\begin{array}{l}\text { Primary raw } \\
\text { material }\end{array}$ & Source/distance & References \\
\hline $\begin{array}{l}\text { Banat sites (Românești, Coșava, } \\
\text { Tincova and Crvenka-At) }\end{array}$ & Banat flint & Meso-local? & Leonard in prep \\
\hline Nagyréde & Hydroquartzite & $<7 \mathrm{~km}$ & $\begin{array}{l}\text { Lengyel et al. } \\
\text { (2006) }\end{array}$ \\
\hline Egerszalók-Kővágó & $\begin{array}{l}\text { Silicified sandstone/ } \\
\text { silicified marl }\end{array}$ & $<7 \mathrm{~km}$ & $\begin{array}{l}\text { Kozłowski et al. } \\
\text { (2009) }\end{array}$ \\
\hline Andornaktálya-Zúgó & $\begin{array}{l}\text { Hydro/limnic } \\
\text { quartzite }\end{array}$ & $<20 \mathrm{~km}$ & $\begin{array}{l}\text { Kozłowski and } \\
\text { Mester (2003) }\end{array}$ \\
\hline Eger-Köporos & $\begin{array}{l}\text { Silicified sandstone/ } \\
\text { silicified marl }\end{array}$ & $15 \mathrm{~km}$ & $\begin{array}{l}\text { Kozłowski et al. } \\
\text { (2012) }\end{array}$ \\
\hline $\begin{array}{l}\text { Hornad Valley sites (Barca, Kechnec, } \\
\text { Seňa, Milhost' and Čečejovce) }\end{array}$ & Limnocilicite & Local & $\begin{array}{l}\text { Kaminská } \\
\quad(2013,2014)\end{array}$ \\
\hline Nižný Hrabovec and Tibava & Chert, claystone & Local & Kaminská (2014) \\
\hline Korolevo & Andesite & Local & $\begin{array}{l}\text { Monigal et al. } \\
\text { (2006) }\end{array}$ \\
\hline Beregovo and Sokirnitsa & $\begin{array}{l}\text { Beregovo flint; } \\
\text { quartzite and slate }\end{array}$ & $\begin{array}{l}\text { Currently under } \\
\text { study; }>20 \mathrm{~km}\end{array}$ & $\begin{array}{l}\text { Monigal et al. } \\
\text { (2006) }\end{array}$ \\
\hline
\end{tabular}

(Leonard in prep). In spite of the apparent raw material abundance and quality, it is notable that a small number $(<5 \%)$ of the Banat tools and other artifacts were made from other semi-local raw materials. However, the small number and their unknown provenience suggests that they may have been transported from unknown sources upstream.

In the northern Carpathian Basin, the situation is markedly different. Here, the availability of raw materials shifts in favor of varieties of local hydroquartzites and other semi-local stones such as radiolarite, obsidian and erratic flints. Although recent work has focused on identifying potential outcrops in the Northern Carpathian region, there are still questions surrounding the local provenience and classification of raw materials (see articles in Mester 2013). The near exclusive use of poor quality local $(<7 \mathrm{~km})$ hydroquartzites at Nagyréde and silicified sandstones at Egerszalók-Kôvágó is in contrast to the other Eger sites (Andornaktálya-Zúgó, Eger-Köporos), where assemblages appear to contain higher quality semi-local and exotic constituents. While it has been suggested that some of this material was transported from across the Carpathians from sources in present-day Poland, the Hornad Valley sites across the border feature nearly exclusively limnosilicites likely acquired from local fluvial sources (Kaminská 2014). The situation is similar farther east at Nižný Hrabovec and Tibava, where lithic raw materials comprise local cherts and claystones, with semi-exotic raw materials such as obsidian also present in small quantities (Kaminská 2014; Williams-Thorpe et al. 1984).

The Upper Tisza Valley has provided further evidence for limited transport and modification of artifacts across the paleolandscape, highlighting a dynamic, mobile 
and structured technological system. The Transcarpathian Ukraine has abundant high-quality materials, and from the long stratigraphy at Korolevo it may be concluded that the site was used as a raw material source for high-quality andesite throughout the Paleolithic. The situation is identical at Beregovo and Sokirnitsa, where artifacts were manufactured on Beregovo flint or quartzite and slate, respectively. Still, at Beregovo, some flint, chalcedony and andesite are believed to be exotic, possibly imported from Korolevo, some $30 \mathrm{~km}$ downstream.

\section{Technocomplex Variability and Patterning}

The early Upper Paleolithic archaeology of the Carpathian Basin exhibits a range of technologies that together form a mosaic of regionally distinct, exceptional and familiar assemblages. However, they are still poorly understood as a result of unclear stratigraphies, poor assemblage contexts, lack of chronological resolution and disparate raw material qualities. While blades dominate the lithic artifact record for the early Upper Paleolithic, they are not always the predominant blank type (such as at Nagyréde) and they often vary considerably in forms and production methods, underscoring the roles of raw materials, site function and local traditions.

Several early Upper Paleolithic technocomplexes from the Carpathian Basin are reported aside from the Aurignacian, including the Initial Upper Paleolithic, Bohunician and Olschewian. The Initial Upper Paleolithic is attested to by some of the Eger sites (Eger-Köporos, Egerszalók-Kővágó), but these sites are unstratified and mixed with numerous Late Pleistocene assemblages, and it is unclear how these industries relate either temporally or technologically to other Initial Upper Paleolithic assemblages across Eurasia (Kuhn and Zwyns 2014). Fifteen Bohunician artifacts are also known from Nižný Hrabovec, where they are found within a palimpsest containing assemblages from the entire Late Pleistocene (Kaminská et al. 2000; Kaminská et al. 2009). The assemblages at Vindija and Velika Pecina have sometimes been ascribed to the Olschewian (a regional Aurignacian variant), because of the presence of both bifaces and bone points (Karavanić 2000), but the integrity of the assemblages is still a matter of debate (Zilhão 2009). Additionally, we lack the formal tools with which to accurately designate the unidentified early Upper Paleolithic assemblages from the Upper Tisza Valley; however, the new excavations at Beregovo I may attest to the presence of proto-Aurignacian features.

Still, early Upper Paleolithic assemblages in the Carpathian Basin have been ascribed to the Aurignacian, none more confidently than the Banat sites which contain Dufour bladelets (subtype Roc de Combe), carinated pieces and prismatic cores. However, to what extent these assemblages are directly comparable to those found in Western Europe, and whether they are relevant to discussions concerning the multi-phasic chronology of the Aurignacian, is still unclear. The highlyfragmented nature of the collections and the scarcity of chronometric data renders the chronocultural attribution of the Banat Aurignacian difficult at present.

Because of their close temporal and spatial proximity, some researchers have emphasized the homologies of Tincova, Coșava (level I), Românești I (level III) and Crvenka-At to Western European Aurignacian collections at Krems-Hundssteig in 
Lower Austria in terms of their techno-typological attributes (Hahn 1977; Mihailović 1992; Mogoșanu 1978). According to a recently resurrected KremsDufour interpretation, the Banat sites belong to a specific Aurignacian facies, itself a 'genuine' part of a techno-typologically uniform pan-European technocomplex (Demidenko and Noiret 2012).

On the other hand, the Tincova assemblage has been used in discussions of the technology of the earliest modern humans reaching the Carpathian Basin during MIS 3, and Teyssandier and Zilhão have suggested that the collection assemblage is 'strongly suggestive of the proto-Aurignacian because of the targeted production of elongated rectilinear blade forms' (Teyssandier 2006, 2008; Zilhão 2006). They have also encouraged additional comparisons with the Kozarnikian further east in Bulgaria, implying that its position might have served as a waypoint between Southeastern and Central Europe. Still, no direct comparative study of any of these sites has been made, and the Tincova site remains undated. If correct, however, these comparisons raise questions as to Tincova's association with the other Banat sites and may be critical to unraveling the validity of the proto-Aurignacian and various other Aurignacian subtypes.

In caves, the Aurignacian is almost exclusively known from bone artifacts, though some researchers have cautioned against taking osseous points as indicators of Aurignacian assemblages when the complementary lithics are not present. However, if accepted, the bone artifacts form a critical part of our understanding of the Carpathian Basin Aurignacian material culture, as they can be directly dated and are sometimes the predominant or only diagnostic Aurignacian artifact present. Most of the bone artifacts are split-based points, though other forms and tools are present (Dobosi 2002). Bone artifacts are exclusively found in the cave sedimentary sequences, undoubtedly a function of better preservation than in the open-air sites but also possibly due to a system of caching for later use (Verpoorte 2012).

\section{Landscape Settlement Patterns}

In spite of the long history of research in the Carpathian Basin, the region has little unambiguous evidence for substantial early modern human occupations. This is in contrast to the presence of dozens of early Upper Paleolithic sites and find spots surrounding the Carpathian Basin and across Western Europe. Although the openair sites of the Banat, southern Slovakia and the Upper Tisza Valley form regional bright spots with large, stratified, sometimes dated early Upper Paleolithic collections in close proximity, there are far more regions where the early Upper Paleolithic record is dim or void of archaeological residues.

This absence is particularly notable in the lowland plains in the heart of the Middle Danube watershed (Fig. 1). This is perplexing, as the regional paleoclimatic studies derived from the loess in exactly these archaeologically-poor areas have borne out the idea that the Carpathian Basin would have been conducive to human occupation. If the Danube is an important trajectory into Europe, and the Carpathian Basin is an important part of this route, why are there so few unambiguous sites? At 
present, the reason for this may be in part methodological (Anghelinu and Niță 2014):

- Large areas of the Carpathian Basin have been lacking in systematic field surveys and excavations. This is the case in many parts of the Carpathian Basin and is exemplified by the southwestern sites in both Bosnia and Eastern Croatia, where there are no well-researched sites.

- Few reliable age estimates have been recovered from archaeological sites in the Carpathian Basin, due to poor organic preservation in the heavily overprinted acidic loess soils and the unclear stratigraphies of past excavations. Although advances in radiocarbon and electron trap techniques (OSL and TL) have begun to ameliorate this situation (e.g. Schmidt et al. 2010; Stevens et al. 2011; Vasiliniuc et al. 2012), they can still be problematic in these ranges and sediments (Timar-Gabor et al. 2011, 2015), and often have error ranges that are too large to allow consequential chronologies to be built.

- Many excavations in the Carpathian Basin, such as in the Bükk, took place at a nascent stage of archaeology, when they frequently resulted in mixed, poorly documented and biased archaeological collections, largely lacking in small chips and contextual information. This is apparent in the extant literature that reveals uneven reporting of archaeological assemblages, with the artifacts being commonly identified simply as either 'absent' or 'present'.

- Additionally, many collections have not been adequately described and/or published. Many industries in the Carpathian Basin have been labeled Aurignacian on the basis of technological attributes. But, as elsewhere, these industry definitions are often unstandardized and/or disparate, consisting of relative artifact amounts as opposed to absolute categories. Detailed technotypological studies and quantification of tool types and reduction techniques have not been performed at most sites, inhibiting our understanding of temporal and spatial characteristics in the Carpathian Basin. This has made it difficult to understand how the Carpathian Basin Aurignacian relates to the type-sites in Central and Western Europe. In the Carpathian Basin, the propensity for local researchers to name their own industries has only exacerbated this problem.

- Although well-stratified sites exist, as in the Banat and the Upper Tisza Valley, the genesis and post-depositional history of many of the regional sediments remains poorly understood. Although Paleolithic researchers in Western Europe have emphasized the role of site taphonomy in assemblage formation, those working in the Carpathian Basin have not fully examined the degree to which natural processes may have played a role in preserving hominin behavioral patterns.

Notwithstanding these methodological shortcomings, which can be problematic even in the best-studied areas, the conspicuous lack of sites in the Carpathian Basin, particularly in the lowland plain, seems to be a genuine phenomenon for which researchers have suggested three functional hypotheses. They argue that this phenomenon may be the result of: 
1. Low hominin demographic density (Karavanić and Smith 2013).

2. Land-use patterns favoring specific topographic zones in the early Upper Paleolithic (Davies et al. 2003).

3. Biases in site visibility due to high-volume sedimentary deposition (Tuffreau et al. 2014) and/or taphonomic processes in the region (Kels et al. 2014; Zilhão and d'Errico 1999).

Understanding the relative validity of these three competing hypotheses is a challenging prerequisite for confronting the role of the Carpathian Basin in early modern human migration patterns.

As for the first hypothesis, the early Upper Paleolithic in the Carpathian Basin truly appears to have particularly low site density, especially when compared to the nearby dense site-concentrations of the Danube in Austria, Moravia and Western Slovakia (Nigst 2006). Low hominin demographics may indeed be a factor in the low findspot density and scanty artifact counts. While it is notoriously difficult to extrapolate paleodemographic estimates, archaeological, climatic and genetic studies agree that during the early Upper Paleolithic they were low indeed (Davies et al. 2015; Fu et al. 2014, 2015, 2016; Seguin-Orlando et al. 2014). However, while low population density may help explain the paucity of archaeological sites, it does not explain the preference for open-air sites in the inner foothills.

As for the second hypothesis, there are few convincing explanations for land-use patterns favoring specific topographic zones, that is, the assumption that the foothills were preferred landscapes. Human foragers subsist through diverse landuse strategies, making use of diverse ecotones as evidenced by their use of both the foothills and high-altitude caves. This shifting between the plane and other altitudinal belts would have allowed, even encouraged, modern humans to make use of the diverse landscapes of the MIS 3 plain to increase their access to fresh water, diverse fauna (including aquatic resources) and raw materials. Using southwestern Romania as an example, Riel-Salvatore et al. (2008) have suggested that higher altitudes positively correlate with artifact curation. Following this logic, we would expect to find higher density sites within the plain itself, a scenario that is not played out in the extant archaeological record.

The validity of hypothesis 3 hinges upon an assumption that there is a systematic taphonomic skew towards the lowlands of the Carpathian Basin, due to either reworking or high Late Pleistocene sedimentation. It is clear from many of the loess profiles in the Danube Valley that several meters of sediments have been deposited since early Upper Paleolithic hominins were present. Additionally, many of the moderately sloped mid-altitude zones where most open-air early Upper Paleolithic sites are located may have experienced significant erosion at the end of the Pleistocene and in the Holocene.

Finally, it is worth pointing out that well-preserved sites and findspots do exist in the plain, for instance at Crvenka-At and potentially Zarilac, which were both identified in alluvial sediments at profound sedimentary depths and only as a result of commercial activity. However, these examples are still by far the exception in the Carpathian Basin, though the many finds and good faunal preservation suggest that 
there are more buried sites near fluvial terraces and paleolake shores that can yield promising results.

In conclusion, scholars have argued that population size and land-use patterns have influenced the composition of the Carpathian Basin's early Upper Paleolithic record. However, given the flexibility of early Upper Paleolithic hunters, the availability of resources in the plain and the virtual absence of Pleistocene archaeological material, it is likely that modern humans used a spectrum of the Carpathian Basin's ecotones and that the absence of archaeological sites in the basin is a taphonomic bias that may be rectified with future research.

\section{Discussion: Early Upper Paleolithic Hominin Dispersals and the Danube Corridor Hypothesis}

Conard and Bolus have asserted that the initial settlement of Europe, especially Central Europe, by modern humans after approximately $40 \mathrm{ka}$ ago was in part achieved by humans 'rapidly enter[ing] the interior of Europe via the Danube Valley' into the Swabian Jura. From there, they would have dispersed further west via various forms of socio-cultural dynamics and/or environmental causality, the socalled Kulturpumpe hypothesis (Conard and Bolus 2003). After reviewing current knowledge of the Carpathian Basin's climatic and archaeological record and the various problems facing both, we return to the question, does the Carpathian Basin early Upper Paleolithic record provide clear evidence for a rapid entry along the Danube corridor during MIS 3?

In short, the Carpathian Basin early Upper Paleolithic record offers limited direct support for this hypothesis beyond the early modern human fossils from the Peștera cu Oase (c. 42.5-40.5 ka cal BP), the lithic assemblages from Românești (c. 42.1$39.1 \mathrm{ka}$ ), and to a lesser extent the single bone point from Peskő (c. 42-40.5 ka cal BP), all of which are broadly coeval with the earliest evidence from the Swabian Jura at Geißenklösterle (c. 43.1-41.5 ka cal BP) but post-date the early Aurignacian remains at Willendorf II (c. $43.5 \mathrm{ka}$ cal BP). This suggests that, at present, only a tenuous direct link (spatially or temporally) can be made between these sites. Furthermore, the other modern human remains at Muierii and Cioclovina and the few securely attributed and radiocarbon-dated Aurignacian sites in the Carpathian Basin all indicate dates that are later than those found farther upstream, pointing to a more sustained occupation of the region.

Still, these limited data points do not refute the Danube corridor hypothesis and there is little to suggest that the Danube could not have been a viable corridor into Europe. By the Late Pleistocene, the incised Danube and Tisza river systems would have created high (dry) alluvial banks that would have formed stable conduits for both humans and fauna. Such rivers may have (in parts) occluded modern human movement into areas of the Carpathian Basin; however, given the early Upper Paleolithic sites west of the Tisza, it is clear that rivers did not pose definitive obstacles to modern humans. Based on their known presence in the highlands (e.g. Peștera cu Oase) and the residues of their movement throughout the foothills, it is possible that they circumvented these barriers by fording the shallow, braided feeder 
rivers along the Carpathian rim. Additionally, if the early lithic remains from Tabula Traiana Cave on the Western bank of the Danube Gorges (at its narrowest point) are telling, we might also envisage scenarios where they traversed large rivers at strategic points where channels narrowed or where river archipelagos were present (e.g. Ada Kaleh Island). Such corridors may have only been periodically available during droughts, or when lower seasonal discharge decreased stream flow and channel breadth/depth exposing point/mid-channel bars, or when sustained cold formed temporary ice bridges. Our current chronological/temporal resolution limits our ability to understand the relationship between early Upper Paleolithic cultural units and Pleistocene rivers, but such a use of the landscape may imply a familiarity inconsistent with a speedy unidirectional dispersal (cf. Hussain and Floss 2016).

The modeled climate for the Carpathian Basin also suggests that there would have been no critical barrier to modern humans entering the region, as is known from periods in the Late Pleistocene (Maier et al. 2016). In fact, it appears that the southern parts of the Carpathian Basin would have been amenable to human occupation even during the colder climatic downswings of MIS 3. This may not have been the case in the Northern Carpathian Basin, where the modeled climatic temperatures indicate a region less temperate than in the south. Nevertheless, climate was not a main challenge for modern humans entering the Carpathian Basin. It is known from the repeated occupations at Willendorf that modern humans were capable of surviving in the temperatures of GIS 11, colder and drier than presentday and harsher than the climates their antecedents endured in the eastern Mediterranean Levant during the Early Pleistocene or even earlier in East Africa. It is also understood that modern humans had mastery of composite extrasomatic technologies such as shelters, clothing and fire, as testified to by the purported habitation structures and hearths at the Slovakian sites (e.g. Aiello and Wheeler 2003; Chu 2009). These would have provided both thermoregulatory benefits against the prevailing cold and wind, and access to locations where fresh water and the associated lithic and faunal resources could be found.

Returning to the most durable part of the archaeological record, the lithics, what can they tell us about the use of the Danube as a corridor? Among the sites located near rivers, for instance in the Banat and southern Slovakia, raw materials were partly tethered to the local fluvial system. However, in other sites, the raw material evidence demonstrates an overwhelming use of locally available lithic sources (despite their quality) for both artifact blanks and tools. There are instances of allochthonous artifacts from southern Poland found in northern Hungary/southern Slovakia, but a guarded interpretation would regard them as stemming from unrecognized local sources or geogenic transport, rather than as anthropogenic traces of long-distance trade systems and wide hunting ranges. If these connections are real, it is interesting to note that they would suggest a path through the Carpathians rather than through the Danube corridor.

While the early Upper Paleolithic lithic assemblages suggest that there was some local flexibility in morphotype, tool ratios, raw materials and flaking capacities, the overall impression is of a blade-dominated industry. Yet where raw materials were of poor quality or small size, hominins manufactured Aurignacian tools on flakes, suggesting that broadly similar hominin behaviors, at least as expressed in lithic 
technology, were implemented across a range of habitats and environments. While often the attribution of these assemblages to the Aurignacian is clear, ascribing them to specific sub-industries (i.e. proto-Aurignacian, late Aurignacian) is difficult. Furthermore, the association between the Carpathian Basin Aurignacian and the early Upper Paleolithic of the Lower Danube sites in Bulgaria (e.g. Temnata, Bacho Kiro) remains unclear.

The landscape settlement patterns of the Aurignacian in the Carpathian Basin also do not suggest a migrating population forging upstream at a rapid pace. It is true that little is known of the Aurignacian sites in the Carpathian Basin; however, it is known that they were not expediently used. Instead, sites in the Carpathian Basin mostly occupy large tracts of land, sometimes over kilometers long (e.g. CrvenkaAt), with considerable artifact density. In certain areas, such as southern Slovakia, the discovery of habitation structures, storage pits and other 'site furniture', implies a more sustained occupation at least on a semi-regular basis (Binford 1979).

Conard and Bolus (2003) have inferred that the animal, plant and lithic resources afforded by the Danube River catchment, combined with a continuous source of human populations from the East, would have set the stage for a precocious entry into Western Europe of modern humans and their associated new technological industries (i.e. the Aurignacian and its various relatives). However, drawing migratory arrows linking similar archaeological findspots to track Pleistocene hominin movements has repeatedly led to erroneous conclusions in the past. Though the Carpathian Basin record currently supports the idea of an exogenous, early entrance of the early Upper Paleolithic into the Carpathian Basin unrelated to any of the preceding MP or transitional industries, the dispersal across the Carpathian Basin is not suggestive of rapid demic expansion, as is evidenced by the relatively late hybridization of the Peștera cu Oase fossil and implied by persistent Mousterian technological elements (Fu et al. 2015; Horvath 2009; Noiret 2005).

This begs the question of where the makers of the early Upper Paleolithic in the Carpathian Basin came from. Aside from a handful of Aurignacian sites (e.g. Bacho Kiro, Temnata) and Kozarnika, whose link to the Aurignacian remains tenuous, no other sites directly connect the Carpathian Basin Aurignacian to the south in the Balkans. Additionally, Anatolia has also to provide empirical evidence of a connection between Southwestern Europe and the early hominin technocomplexes of the Levant. Therefore, a western source for the Carpathian Basin early Upper Paleolithic is conceivable, especially considering the early Willendorf dates which, if correct, pre-date any of the evidence in the Carpathian Basin. If the Danube was as easy a conduit as has been suggested, it is equally likely that it may have seen hominin movement in the opposite direction (Sitlivy et al. 2014). Indeed, increasing genetic and archaeological evidence (Adler et al. 2008; Anikovich et al. 2007; López et al. 2016) supports the idea that the earliest modern humans coming from the Middle East and into Europe may have bypassed Southeastern Europe (at least overland), opting for a route running through the Caucasus, dispersing east through the East European Plain and then north of the Carpathians.

The recent reanalysis of Central European early Upper Paleolithic assemblages and possibly Initial Upper Paleolithic sensu lato finds farther east in the geographically connected Moravian Plains (Bohunician) suggests that early modern 
humans were present in Central Europe far sooner than previously recognized (Müller et al. 2011; Nigst et al. 2014; Richter et al. 2008, 2009). This notion could lead to a major modification in our understanding of the origin and cultural ontogeny of the Aurignacian technocomplex (Sitlivy et al. 2014).

This suggests that while hominins were undoubtedly present within the Middle Danube catchment in the late Upper Pleistocene, it is currently difficult to tell from the archaeological record whether they entered the Carpathian Basin on direct 'highways', in waves (Hublin 2015), or more piecemeal; furthermore, the evidence is too sparse to suggest a directional trajectory. Indeed, the gap in the Danube record suggests that the situation may be more complicated than has previously been thought. Furthermore, climatic reconstructions, illustrated by advances in loess stratigraphy, faunal/floral records and geochemistry, suggest a necessary diversion from the rugged karstic regions of the basin that may have been more familiar hunting areas for previous (Neanderthal) populations. This may have resulted in more frequent or seasonal use of the lowlands within the earlier parts of MIS 3 that may have prompted subsequent modifications in hominin subsistence behavior. A prolonged/intense modern human presence in the Carpathian Basin throughout the late Upper Pleistocene is testified to by a higher frequency of lithic sites with increased artifact density. Increased sedimentation rates in the later part of the Pleistocene may have also helped to offset the palimpsest effect that might have skewed the record.

\section{Conclusions, Summary and Future Research}

Archaeological research has confirmed the presence of modern humans and early Upper Paleolithic sites in scattered parts of the Carpathian Basin. Despite the importance of the Carpathian Basin early Upper Paleolithic to paleoanthropological models, there has been no systematic attempt to examine how Carpathian Basin industries figure in linking the Aurignacian of Western Europe and the Bachokirian and Kozarnikian of Southeastern Europe. In situations such as that of the earliest occupation of Europe by modern humans, where the chronological resolution is insufficient to transform the archaeological record into a coherent cultural narrative, it is appealing to use large geographic features such as the Danube to explain cultural migration routes. While rivers may have served as valuable migration axes in the early Upper Paleolithic and even earlier (Ashton et al. 2006), they do not preclude other productive biomes, which may have been welcome alternatives to climatic variations in both annual and longer timescales. Furthermore, if the Danube did play a role in the migration route of modern humans in the Carpathian Basin, we currently lack the archaeological resolution to tell us in what direction it may have been used.

This paper has reviewed the geological, climatological and archaeological record of the Carpathian Basin, summed up in the following points: 
- The climate of the early Upper Paleolithic of the Carpathian Basin during MIS 3 is characterized by cool-temperate climates and possible mosaic environments that would have provided access to a variety of potential resources.

- The early Upper Paleolithic of the Carpathian Basin has been refined in recent years as a result of new excavations and fieldwork and/or the contextualization of older collections, though most sites remain undated and poorly understood.

- The earliest modern human presence in the Carpathian Basin is testified to directly by the Peștera cu Oase fossils and indirectly by early Aurignacian assemblages in the Banat and a single directly-dated bone point from Peskő. There are, additionally, early blade assemblages in the Upper Tisza Valley, with additional sites in the Northern Carpathians and findspots elsewhere along the foothills.

- Robust ages and site formation processes for most Carpathian Basin sites are still largely unknown but are central to understanding the early Upper Paleolithic archaeological record.

- Human traces in the lowlands of the Carpathian Basin are absent, probably as a result of taphonomic biases.

- The perception of the Danube as a main artery for humans to flow into Europe is undermined by a shortage of viable sites throughout the Carpathian Basin. A better understanding of the chronology of early Upper Paleolithic assemblages, as well as new discoveries, could present new challenges to, or confirmations of, the Danube corridor hypothesis.

Given the sparse archaeological record, it is clear that robust testable hypotheses concerning the early Upper Paleolithic record of the Carpathian Basin can only be formulated with the location of new sites as opposed to the continued analysis of old excavations, for which most stratigraphic/contextual information has now been lost (e.g. the Bükk and Zagorje cave sites). Such an approach includes broadening our search to areas where little research has been conducted, paying particular attention to the basin margins, intermountain basins (e.g. Požega Valley, Croatia), paleolake shores and fluvial terraces where loess and other fine-grained mantles are thin or accessible (Tourloukis 2016). Such efforts may be amplified by predictive modeling (e.g. using slope, aspect, distance to water and lithic resources), systematic amateur stray-find recording, and shallow geophysical techniques. Efforts may also productively be directed towards the re-excavation of 'flagship sites', focused on obtaining radiometric dates and understanding their site formation processes. Both approaches are essential to building reliable archaeological distributions and chronology for the Carpathian Basin early Upper Paleolithic record. Integrating these methodological tools would enhance the reliability of model-bound approaches, giving us a better understanding of how and when the earliest modern humans entered Europe.

Acknowledgements This work benefitted from the support and discussions with Jürgen Richter and Thomas Hauck. Andreas Maier and Christian Zeeden provided valuable comments on an earlier version of this work. Many thanks also to Nikola Vukosavljevic, Gyuri Lengyel, Ľubomíra Kaminská, Tímea Kiss, Karin Kindermann, Adrian Doboș, Alexandru Ciornei and Zsolt Mester for helpful discussions. This work has also been aided by Isabell Schmidt who helped refine the list of archaeological sites, Andreas 
Bolton, who helped design Fig. 1, Lutz Hermsdorf-Knauth and Janina Bösken who helped with Fig. 2, and Anja Rüschmann, who helped with the artifact illustrations. I would also like to thank the Editor in Chief Timothy Taylor and the Managing Editor Sarah Wright along with the anonymous referees for their comments, which improved the final text. This paper has profited from the research of colleagues in the European Paleolithic and Quaternary Science communities: any misrepresentations or errors are my own. This research was undertaken at the University of Cologne as part of the Collaborative Research Center 806 (CRC 806) funded by the Deutsche Forschungsgemeinschaft (DFG).

Open Access This article is distributed under the terms of the Creative Commons Attribution 4.0 International License (http://creativecommons.org/licenses/by/4.0/), which permits unrestricted use, distribution, and reproduction in any medium, provided you give appropriate credit to the original author (s) and the source, provide a link to the Creative Commons license, and indicate if changes were made.

\section{References}

Adams, B. (1998). The Middle to Upper Paleolithic transition in Central Europe: The record from the Bükk Mountain region. Oxford: Archaeopress.

Adams, B. (2002). New radiocarbon dates from Szeleta and Istállóskő caves, Hungary. Praehistoria, 3, 53-55.

Adams, B. (2009). The Bükk Mountain Szeletian: Old and new views on 'transitional' material from the eponymous site of the Szeletian. In M. Camps \& P. R. Chauhan (Eds.), Sourcebook of Paleolithic transitions (pp. 427-440). New York: Springer.

Adams, B., \& Ringer, A. (2004). New C14 dates for the Hungarian early Upper Palaeolithic. Current Anthropology, 45(4), 541-551. https://doi.org/10.1086/ca.2004.45.issue-4.

Adler, D. S., Bar-Yosef, O., Belfer-Cohen, A., Tushabramishvili, N., Boaretto, E., Mercier, N., et al. (2008). Dating the demise: Neandertal extinction and the establishment of modern humans in the southern Caucasus. Journal of Human Evolution, 55, 817-833.

Ahern, J. C. M., Karavanić, I., Paunović, M., Janković, I., \& Smith, F. H. (2004). New discoveries and interpretations of hominid fossils and artifacts from Vindija Cave, Croatia. Journal of Human Evolution, 46(1), 27-67. https://doi.org/10.1016/j.jhevol.2003.09.010.

Aiello, L., \& Wheeler, P. (2003). Neanderthal thermoregulation and the glacial climate. In T. H. van Andel \& W. Davies (Eds.), Neanderthals and modern humans in the European landscape during the last glaciation: Archaeological results of the stage 3 project (pp. 147-166). Cambridge: McDonald Institute for Archaeological Research.

Alexandrescu, E., Olariu, A., Skog, G., Stenström, K., \& Hellborg, R. (2010). Os fossiles humains des grottes Muierii et Cioclovina, Roumanie. L'Anthropologie, 114(3), 341-353. https://doi.org/10.1016/ j.anthro.2010.05.004.

Anghelinu, M. (1998). Un decupaj analitic al arheologiei paleoliticului din românia. Materiale și Cercetări Arheologice, 11, 271-282.

Anghelinu, M., \& Niță, L. (2014). What's in a name: The Aurignacian in Romania. Quaternary International, 351, 172-192. https://doi.org/10.1016/j.quaint.2012.03.013.

Anghelinu, M., Niță, L., Sitlivy, V., Uthmeier, T., \& Băltean, I. (2012). Looking around Peștera cu Oase: The beginnings of Upper Paleolithic in Romania. Quaternary International, 274, 136-157. https:// doi.org/10.1016/j.quaint.2012.01.012.

Anghelinu, M., Niță, L., \& Steguweit, L. (2012). Not that original after all: The chrono-cultural framework of the Upper Paleolithic on the Bistrița Valley (Northeastern Romania). Arheologia Moldovei, 35, 7-14.

Anikovich, M. (1992). Early Upper Paleolithic industries of Eastern Europe. Journal of World Prehistory, 6(2), 205-245. https://doi.org/10.1007/BF00975550.

Anikovich, M., Sinitsyn, A., Hoffecker, J. F., Holliday, V., Popov, V., Lisitsyn, S., et al. (2007). Early Upper Paleolithic in Eastern Europe and implications for the dispersal of modern humans. Science, 315, 223-226. https://doi.org/10.1126/science.1133376. 
Antoine, P., Rousseau, D.-D., Fuchs, M., Hatté, C., Gauthier, C., Marković, S. B., et al. (2009). Highresolution record of the last climatic cycle in the southern Carpathian Basin (Surduk, Vojvodina, Serbia). Quaternary International, 198(1-2), 19-36. https://doi.org/10.1016/j.quaint.2008.12.008.

Ashton, N., Lewis, S. G., Parfitt, S. A., \& White, M. J. (2006). Riparian landscapes and human habitat preferences during the Hoxnian (MIS 11) interglacial. Journal of Quaternary Science, 21, 497-505. https://doi.org/10.1002/jqs.1032.

Banak, A., Mandić, O., Kovačić, M., \& Pavelić, D. (2012). Late Pleistocene climate history of the Baranja loess plateau: Evidence from the Zmajevac loess-paleosol section (northeastern Croatia). Geologia Croatica, 65(3), 411-422.

Banak, A., Mandic, O., Sprovieri, M., Lirer, F., \& Pavelić, D. (2016). Stable isotope data from loess malacofauna: Evidence for climate changes in the Pannonian Basin during the Late Pleistocene. Quaternary International, 415, 15-24. https://doi.org/10.1016/j.quaint.2015.10.102.

Bánesz, L. (1958). Mladopaleolitické objekty v Seni I. Slovenská Archeológia, 6, 5-20.

Bánesz, L. (1960). Die Problematik der Paläolithischen Besiedlung in Tibava. Slovenská Archeológia, 7 , $7-58$.

Barta, G. (2014). Paleoenvironmental reconstruction based on the morphology and distribution of secondary carbonates of the loess-paleosol sequence at Süttô, Hungary. Quaternary International, 319, 64-75. https://doi.org/10.1016/j.quaint.2013.08.019.

Bárta, J. (1987). Problems of dwelling structures in the Palaeolithic of western Slovakia. Anthropologie, 25(2), 105-110.

Bartosiewicz, L. (2016). Archaeology in Hungary 1948-1989. In L. R. Lozny (Ed.), Archaeology of the communist era: A political history of archaeology of the 20th century (pp. 195-233). New York: Springer.

Bar-Yosef, O. (1998). On the nature of transitions: The Middle to Upper Palaeolithic and the Neolithic revolution. Cambridge Archaeological Journal, 8(2), 141-163. https://doi.org/10.1017/ S0959774300001815.

Basarin, B., et al. (2014). Time-scale and astronomical forcing of Serbian loess-palaeosol sequences. Global and Planetary Change, 122, 89-106. https://doi.org/10.1016/j.gloplacha.2014.08.007.

Basler, Đ. (1979). Nalazište Paleolitskog i Mezolitskog doba u Bosni i Hercegovini. Praistorija jugoslovenskih zemalja-I-Paleolit i Mezolit (The Prehistory of the Yugoslav Countries-I-Paleolithic and Mesolithic) (pp. 313-330). Sarajevo: Svjetlost.

Binford, L. R. (1979). Organization and formation processes: Looking at curated technologies. Journal of Anthropological Research, 35(3), 255-273.

Biró, K. T. (2009). Sourcing raw materials for chipped stone artifacts: The state-of-the-art in Hungary and the Carpathian Basin. In B. Adams \& B. S. Blades (Eds.), Lithic materials and Paleolithic societies (pp. 47-53). Hoboken: Wiley-Blackwell.

Blaauw, M. (2012). Out of tune: The dangers of aligning proxy archives. Quaternary Science Reviews, 36, 38-49. https://doi.org/10.1016/j.quascirev.2010.11.012.

Bokhorst, M. (2009). Last glacial climate variability in Eastern and Central Europe as recorded in loess deposits. Amsterdam: Vrije Universiteit Amsterdam.

Bokhorst, M., Beets, C. J., Marković, S. B., Gerasimenko, N. P., Matviishina, Z. N., \& Frechen, M. (2009). Pedo-chemical climate proxies in Late Pleistocene Serbian-Ukrainian loess sequences. Quaternary International, 198(1-2), 113-123. https://doi.org/10.1016/j.quaint.2008.09.003.

Bokhorst, M., \& Vandenberghe, J. (2009). Validation of wiggle matching using a multi-proxy approach and its palaeoclimatic significance. Journal of Quaternary Science, 24(8), 937-947. https://doi.org/ 10.1002/jqs. 1271.

Bokhorst, M., Vandenberghe, J., Sümegi, P., Łanczont, M., Gerasimenko, N. P., Matviishina, Z. N., et al. (2011). Atmospheric circulation patterns in Central and Eastern Europe during the Weichselian Pleniglacial inferred from loess grain-size records. Quaternary International, 234(1-2), 62-74. https://doi.org/10.1016/j.quaint.2010.07.018.

Borić, D., Dimitrijević, V., White, D., Lane, C., French, C., \& Cristiani, E. (2012). Early modern human settling of the Danube corridor: The Middle to Upper Palaeolithic site of Tabula Traiana Cave in the Danube gorges (Serbia). Antiquity, 86(334). http://www.antiquity.ac.uk/projgall/boric334/.

Bradák, B., \& Kovács, J. (2014). Quaternary surface processes indicated by the magnetic fabric of undisturbed, reworked and fine-layered loess in Hungary. Quaternary International, 319, 76-87. https://doi.org/10.1016/j.quaint.2013.02.009. 
Budek, A., Kalicki, T., Kaminská, L., Kozłowski, J. K., \& Mester, Z. (2013). Interpleniglacial profiles on open-air sites in Hungary and Slovakia. Quaternary International, 294, 82-98. https://doi.org/10. 1016/j.quaint.2012.02.022.

Buggle, B., Glaser, B., Zöller, L., Hambach, U., Marković, S. B., Glaser, I., et al. (2008). Geochemical characterization and origin of Southeastern and Eastern European loesses (Serbia, Romania, Ukraine). Quaternary Science Reviews, 27(9-10), 1058-1075. https://doi.org/10.1016/j.quascirev. 2008.01.018.

Buggle, B., Hambach, U., Glaser, B., Gerasimenko, N., Marković, S., Glaser, I., et al. (2009). Stratigraphy, and spatial and temporal paleoclimatic trends in Southeastern/Eastern European loesspaleosol sequences. Quaternary International, 196(1-2), 86-106. https://doi.org/10.1016/j.quaint. 2008.07.013.

Buggle, B., Hambach, U., Kehl, M., Marković, S. B., Zöller, L., \& Glaser, B. (2013). The progressive evolution of a continental climate in southeast-central European lowlands during the Middle Pleistocene recorded in loess paleosol sequences. Geology, 41(7), 771-774. https://doi.org/10.1130/ G34198.1.

Buggle, B., \& Zech, M. (2015). New frontiers in the molecular based reconstruction of Quaternary paleovegetation from loess and paleosols. Quaternary International, 372, 180-187. https://doi.org/ 10.1016/j.quaint.2015.02.046.

Cârciumaru, M., \& Anghelinu, M. (2000). The Carpathian Mousterian and the transition from Middle to Upper Palaeolithic. In J. Orschiedt \& G.-C. Weniger (Eds.), Neanderthals and modern humansdiscussing the transition: Central Eastern Europe from 50.000-30.000 B.P. (pp. 190-195). Mettmann: Neanderthal Museum.

Cârciumaru, M., Cosac, M., Nițu, E.-C. (2004). Les datations C-14 et la succession culturelle du Paléolithique, Epipaléolithique de la Roumanie. Annales d'Université 'Valahia' Târgoviște, Section d'Archéologie et d'Histoire, 6-7, 7-43.

Cârciumaru, M., Nițu, E.-C., Dobrescu, R., \& Ștefănescu, R. (2010). Paleoliticul din județul Brașov. Târgoviște: Valahia University Press.

Chu, W. (2009). A functional approach to Paleolithic open-air habitation structures. World Archaeology, 41, 348-362.

Chu, W., Hauck, T., \& Mihailović, D. (2014). Crvenka-At: Preliminary results from a lowland Aurignacian site in the Middle Danube catchment. In D. Mihailović (Ed.), Palaeolithic and Mesolithic research in the central Balkans (pp. 69-75). Belgrade: Serbian Archaeological Society.

Chu, W., Lengyel, G., Zeeden, C., Péntek, A., Kaminská, L., \& Mester, Z. (2017). Early Upper Paleolithic surface collections from loess-like sediments in the northern Carpathian Basin. Quaternary International. https://doi.org/10.1016/j.quaint.2017.05.017.

Chu, W., Mihailović, D., Pantović, I., Hauck, T., \& Lehmkuhl, F. (2016). Archaeological excavations at the site of At (Vršac, Serbia). Antiquity, 90(352). http://antiquity.ac.uk/projgall/chu352.

Chu, W., Zeeden, C., \& Petrescu, S. (2016). The Early Upper Paleolithic of the Banat and recent research at the Paleolithic site of Tincova. Banatica, 26(1), 51-72.

Conard, N. J., \& Bolus, M. (2003). Radiocarbon dating the appearance of modern humans and timing of cultural innovations in Europe: New results and new challenges. Journal of Human Evolution, 44, 331-371. https://doi.org/10.1016/S0047-2484(02)00202-6.

Conard, N. J., \& Bolus, M. (2008). Radiocarbon dating the late Middle Paleolithic and the Aurignacian of the Swabian Jura. Journal of Human Evolution, 55, 886-897. https://doi.org/10.1016/j.jhevol.2008. 08.006.

Constantin, S., Bojar, A.-V., Lauritzen, S.-E., \& Lundberg, J. (2007). Holocene and Late Pleistocene climate in the sub-Mediterranean continental environment: A speleothem record from Poleva Cave (southern Carpathians, Romania). Palaeogeography, Palaeoclimatology, Palaeoecology, 243(3-4), 322-338. https://doi.org/10.1016/j.palaeo.2006.08.001.

Cosac, M., Muratoreanu, G., \& Radu, A. (2013). Aşezarea paleolitică de la "Malu Dinu Buzea" - sat Cremenea, com. Sita Buzăului, jud. Covasna, România. O sinteză a campaniilor 2010-2013 - date geomorfologice şi stratigrafice. In A. Stavilă \& L. Măruia (Eds.), In memoriam Liviu Măruia: Timişoara, 7 decembrie 2013. 2 2. Szeged: JatePress Kiadó.

Cosac, M., Muratoreanu, G., Radu, A., \& Niță, L. (2015). The Palaeolithic settlement from Malu Dinu Buzea (Cremenea village, Sita Buzăului commune, Covasna county). A synthesis of the excavation campaigns from 2011-2013. Materiale și Cercetări Arheologice, 11, 81-100.

Crandell, O., Niță, L., \& Anghelinu, M. (2013). Long-distance imported lithic raw materials at the Upper Palaeolithic sites of the Bistrița Valley (Carpathian Mts.), Eastern Romania. Lithics, 34, 30-42. 
Csekö, G., \& Hayde, L. (2004). Danube Valley: History of irrigation, drainage, and flood control. New Delhi: International Commission on Irrigation and Drainage.

Cserkész-Nagy, Á., Thamó-Bozsó, E., Tóth, T., \& Sztanó, O. (2012). Reconstruction of a Pleistocene meandering river in East Hungary by VHR seismic images, and its climatic implications. Geomorphology, 153-154, 205-218. https://doi.org/10.1016/j.geomorph.2012.02.025.

d'Errico, F., Banks, W. E., Vanhaeren, M., Laroulandie, V., \& Langlais, M. (2011). PACEA georeferenced radiocarbon database. PaleoAnthropology, 2011, 1-12.

Damblon, F., \& Haesaerts, P. (2007). Les datations 14C à Mitoc-Malu Galben. In M. Otte, P. Haesaerts \& V. Chirica (Eds.), L'Aurignacien et le Gravettien de Mitoc-Malu Galben (Moldavie Roumaine) (pp. 53-65). Liège: ERAUL 72.

Davies, W., \& Hedges, R. (2008). Dating a type site: Fitting Szeleta Cave into its regional chronometric context. Praehistoria, 9, 35-45.

Davies, W., Valdes, P., Ross, C. A., \& van Andel, T. H. (2003). The human presence in Europe during the last glacial period III: Site clusters, regional climates, and resource attractions. In T. H. van Andel \& W. Davies (Eds.), Neanderthals and modern humans in the European landscape during the last glaciation: Archaeological results of the stage 3 project (pp. 191-220). Cambridge: McDonald Institute for Archaeological Research.

Davies, W., White, D., Lewis, M., \& Stringer, C. (2015). Evaluating the transitional mosaic: Frameworks of change from Neanderthals to Homo sapiens in Eastern Europe. Quaternary Science Reviews, 118 (15), 211-242. https://doi.org/10.1016/j.quascirev.2014.12.003.

Demidenko, Y. E., \& Noiret, P. (2012). The Siuren-I Aurignacian of Krems-Dufour type industries in the context of the European Aurignacian. In Y. E. Demidenko, M. Otte, \& P. Noiret (Eds.), Siuren I rock-shelter: From late Middle Paleolithic and early Upper Paleolithic to Epi-Paleolithic in Crimea (pp. 343-357). Liège: ERAUL 129.

Doboș, A., Soficaru, A., \& Trinkaus, E. (2010). The prehistory and paleontology of the Peștera Muierii (Romania). Liège: ERAUL 124.

Dobosi, V. T. (1995). Eger-Köporostetö: Révision d'une industrie à outils foliacés. Paléo. Supplément, 1 (1), 45-55. https://doi.org/10.3406/pal.1995.1379.

Dobosi, V. T. (2002). Bone finds from Istállós-kő Cave. Praehistoria, 3, 79-102.

Dobosi, V. T. (2008). Acsa: New open-air Aurignacian site in Hungary. In Z. Sulgostowska \& R. Schild (Eds.), Man, millennia, environment: Studies in honour of Romuald Schild (pp. 151-160). Warsaw: Institute of Archaeology and Ethnology, Polish Academy of Sciences.

Dobosi, V. T. (2013). Acsa-Rovnya: Új eredmények (Acsa-Rovnya: New results). Litikum, 1, 50-59.

Dobrescu, R. (2008). Aurignacianul din Transilvania. Bucharest: Renaissance.

Dragoman, R.-A., \& Oanţă-Marghitu, S. (2006). Archaeology in communist and post-communist Romania. Dacia, 50, 58-76.

Feurdean, A., Perșoiu, A., Tanțău, I., Stevens, T., Magyari, E. K., Onac, B. P., et al. (2014). Climate variability and associated vegetation response throughout Central and Eastern Europe (CEE) between 60 and 8 ka. Quaternary Science Reviews, 106, 206-224. https://doi.org/10.1016/j. quascirev.2014.06.003.

Fitzsimmons, K. E., Marković, S. B., \& Hambach, U. (2012). Pleistocene environmental dynamics recorded in the loess of the Middle and Lower Danube Basin. Quaternary Science Reviews, 41, 104118. https://doi.org/10.1016/j.quascirev.2012.03.002.

Frechen, M., Horváth, E., \& Gábris, G. (1997). Geochronology of Middle and Upper Pleistocene loess sections in Hungary. Quaternary Research, 48(3), 291-312. https://doi.org/10.1006/qres.1997.1929.

Frenzel, B., Pécsi, M., \& Velichko, A. A. (Eds.). (1992). Atlas of paleoclimates and paleoenvironments of the Northern Hemisphere: Late Pleistocene, Holocene. Budapest: Geographical Research Institute, Hungarian Academy of Science.

Fu, Q., Hajdinjak, M., Moldovan, O. T., Constantin, S., Mallick, S., Skoglund, P., et al. (2015). An early modern human from Romania with a recent Neanderthal ancestor. Nature, 524(7564), 216-219. https://doi.org/10.1038/nature14558.

Fu, Q., Li, H., Moorjani, P., Jay, F., Slepchenko, S. M., Bondarev, A. A., et al. (2014). Genome sequence of a 45,000-year-old modern human from western Siberia. Nature, 514(7523), 445-449. https://doi. org/10.1038/nature13810.

Fu, Q., Posth, C., Hajdinjak, M., Petr, M., Mallick, S., Fernandes, D., et al. (2016). The genetic history of Ice Age Europe. Nature, 534(7606), 200-205. https://doi.org/10.1038/nature17993. 
Fuchs, M., Rousseau, D.-D., Antoine, P., Hatté, C., Gauthier, C., Marković, S., et al. (2008). Chronology of the last climatic cycle (Upper Pleistocene) of the Surduk loess sequence, Vojvodina, Serbia. Boreas, 37(1), 66-73. https://doi.org/10.1111/j.1502-3885.2007.00012.x.

Gábris, G. (1994). Pleistocene evolution of the Danube in the Carpathian Basin. Terra Nova, 6(5), 495501. https://doi.org/10.1111/j.1365-3121.1994.tb00893.x.

Gábris, G., Horváth, E., Novothny, Á., \& Ruszkiczay-Rüdiger, Z. (2012). Fluvial and aeolian landscape evolution in Hungary: Results of the last 20 years research. Netherlands Journal of Geosciences, 91 (1-2), 111-128. https://doi.org/10.1017/S0016774600001530.

Gábris, G., \& Nádor, A. (2007). Long-term fluvial archives in Hungary: Response of the Danube and Tisza rivers to tectonic movements and climatic changes during the Quaternary-A review and new synthesis. Quaternary Science Reviews, 26(22-24), 2758-2782. https://doi.org/10.1016/j.quascirev. 2007.06.030.

Galović, L., Frechen, M., Halamić, J., Durn, G., \& Romić, M. (2009). Loess chronostratigraphy in eastern Croatia: A luminescence dating approach. Quaternary International, 198(1-2), 85-97. https://doi. org/10.1016/j.quaint.2008.02.004.

Geyh, M., Schweitzer, F., Vértes, L., \& Vogel, I. (1969). A magyarországi würmi eljegesedés új kronológiai adatai. (New chronological data of the Weichselian glaciation in Hungary). Földrajzi Közlemények, 18, 5-18.

Goldberg, P., \& Macphail, R. I. (2009). Practical and theoretical geoarchaeology. Malden: Wiley.

Haesaerts, P., \& Teyssandier, N. (2003). The Early Upper Paleolithic occupations of Willendorf II (Lower Austria): A contribution to the chronostratigraphic and cultural context of the beginning of the Upper Paleolithic in Central Europe. In J. Zilhão \& F. d'Errico (Eds.), The chronology of the Aurignacian and of the transitional technocomplexes: Dating, stratigraphies, cultural implications (pp. 133-151). Lisbon: Instituto Portugês de Arqueologia.

Häggi, C., Zech, R., McIntyre, C., \& Eglinton, T. (2013). On the stratigraphic integrity of leaf-wax biomarkers in loess-paleosols. Biogeosciences Discussions, 10(10), 16903-16922.

Hahn, J. (1977). Aurignacien, das ältere Jungpaläolithikum in Mittel- und Osteuropa. Köln: Böhlau Verlag.

Händel, M., Simon, U., Einwögerer, T., \& Neugebauer-Maresch, C. (2009). Loess deposits and the conservation of the archaeological record: The Krems-Wachtberg example. Quaternary International, 198(1-2), 46-50. https://doi.org/10.1016/j.quaint.2008.07.005.

Harvati, K., Gunz, P., \& Grigorescu, D. (2007). Cioclovina (Romania): Affinities of an early modern European. Journal of Human Evolution, 53(6), 732-746. https://doi.org/10.1016/j.jhevol.2007.09. 009.

Hatté, C., Gauthier, C., Rousseau, D.-D., Antoine, P., Fuchs, M., Lagroix, F., et al. (2013). Excursions to C4 vegetation recorded in the Upper Pleistocene loess of Surduk (northern Serbia): An organic isotope geochemistry study. Climate of the Past, 9(3), 1001-1014. https://doi.org/10.5194/cp-91001-2013.

Hauck, T., Rethemeyer, J., Rentzel, P., Schulte, P., Fulop, R., Heinze, A., et al. (2016). Neandertals or early modern humans? A revised $14 \mathrm{C}$ chronology and geoarchaeological study of the Szeletian sequence in Szeleta Cave (Hungary). Archäologisches Korrespondenzblatt, 46(3), 271-290.

Hertelendi, E., Sümegi, P., \& Szöör, G. (1992). Geochronologic and paleoclimatic characterization of Quaternary sediments in the Great Hungarian Plan. Radiocarbon, 34, 833-839.

Higham, T., Basell, L., Jacobi, R., Wood, R., Ramsey, C. B., \& Conard, N. J. (2012). Testing models for the beginnings of the Aurignacian and the advent of figurative art and music: The radiocarbon chronology of Geißenklösterle. Journal of Human Evolution, 62(6), 664-676. https://doi.org/10. 1016/j.jhevol.2012.03.003.

Higham, T., Ramsey, C. B., Karavanić, I., Smith, F. H., \& Trinkaus, E. (2006). Revised direct radiocarbon dating of the Vindija G1 Upper Paleolithic Neandertals. Proceedings of the National Academy of Sciences, 103(3), 553-557. https://doi.org/10.1073/pnas.0510005103.

Honea, K. (1990). Recent advances in modern archaeological dating (AMS, ESR, 234U-230Th): First Oxford AMS dates for Mitoc-Malu Galben. Arheologia Moldovei, 13, 9-12.

Horvath, I. (2009). The Early Upper Palaeolithic in Romania: Past and current research. In M. Camps \& C. Szmidt (Eds.), The Mediterranean from 50000 to 25000 BP: Turning points and new directions (pp. 137-162). Oxford: Oxbow Books.

Horváth, F. (1993). Towards a mechanical model for the formation of the Pannonian Basin. Tectonophysics, 226(1-4), 333-357. https://doi.org/10.1016/0040-1951(93)90126-5. 
Horváth, F., Musitz, B., Balázs, A., Végh, A., Uhrin, A., Nádor, A., et al. (2015). Evolution of the Pannonian Basin and its geothermal resources. Geothermics, 53, 328-352. https://doi.org/10.1016/j. geothermics.2014.07.009.

Hublin, J.-J. (2015). The modern human colonization of western Eurasia: When and where? Quaternary Science Reviews, 118, 194-210. https://doi.org/10.1016/j.quascirev.2014.08.011.

Hupuczi, J., Molnár, D., Galović, L., \& Sümegi, P. (2010). Preliminary malacological investigation of the loess profile at Šarengrad, Croatia. Open Geosciences, 2(1), 57-63. https://doi.org/10.2478/v10085009-0048-x.

Hupuczi, J., \& Sümegi, P. (2010). The Late Pleistocene paleoenvironment and paleoclimate of the Madaras section (South Hungary), based on preliminary records from mollusks. Open Geosciences, 2(1), 64-70. https://doi.org/10.2478/v10085-009-0044-1.

Hussain, S. T., \& Floss, H. (2016). Streams as entanglement of nature and culture: European Upper Paleolithic river systems and their role as features of spatial organization. Journal of Archaeological Method and Theory, 23(4), 1162-1218. https://doi.org/10.1007/s10816-015-9263-x.

Ioviță, R., Doboș, A., Fitzsimmons, K. E., Probst, M., Hambach, U., Robu, M., et al. (2014). Geoarchaeological prospection in the loess steppe: Preliminary results from the Lower Danube survey for Paleolithic sites (LoDanS). Quaternary International, 351, 98-114. https://doi.org/10. 1016/j.quaint.2013.05.018.

Jámbor, Á. (2012). Quaternary evolution. In J. Haas (Ed.), Geology of Hungary (pp. 201-213). Heidelberg: Springer.

Janković, I., Karavanić, I., Ahern, J. C. M., Brajković, D., Mauch Lenardić, J., \& Smith, F. H. (2006). Vindija Cave and the modern human peopling of Europe. Collegium Antropologicum, 30(3), 457466.

Jánossy, D. (2011). Pleistocene vertebrate faunas of Hungary. New York: Elsevier.

Jovanović, I., Pandžić, I., \& Miracle, P. T. (2014). The chipped stone industry from Rastuša Cave. Bana Luka: University of Bana Luka.

Kaminská, L. (2013). Sources of raw materials and their use in the Palaeolithic of Slovakia. In Z. Mester (Ed.), The lithic raw material sources and interregional human contacts in the Northern Carpathian regions (pp. 99-109). Krakow: Polska Akademia Umiejętności.

Kaminská, L. (2014). Staré Slovensko 2: Paleolit a Mezolit. Nitra: Archeologický Ústav Sav Nitra.

Kaminská, L., Kozłowski, J., Kazior, B., Pawlikowski, M., \& Sobczyk, K. (2000). Long term stability of raw materials procurement systems in the Middle and Upper Palaeolithic of Eastern Slovakia: A case study of the Topla/Ondava river valleys. Praehistoria, 1, 63-81.

Kaminská, L., Škrdla, P., Kozlowski, J. K., \& Tomášková, S. (2009). Nižný Hrabovec: A site with evolved Levallois technology in Eastern Slovakia. Eurasian Prehistory, 6(1-2), 57-64.

Karavanić, I. (1995). Upper Paleolithic occupation levels and late-occurring Neandertal at Vindija Cave (Croatia) in the context of Central Europe and the Balkans. Journal of Anthropological Research, 51 (1), 9-35.

Karavanić, I. (1998). The Early Upper Paleolithic of Croatia. In F. Facchini, A. Palma di Cesnola, M. Piperno, \& C. Pretty (Eds.), XIII International Congress of prehistoric and protohistoric sciences. Proceedings (Vol. 2, pp. 659-665). Abaco: Forli.

Karavanić, I. (2000). Olschevian and appearance of bone technology in Croatia and Slovenia. In J. Orschiedt \& G.-C. Weniger (Eds.), Neanderthals and modern humans - Discussing the transition: Central Eastern Europe from 50.000-30.000 BP (pp. 159-168). Mettmann: Neanderthal Museum.

Karavanić, I., \& Janković, I. (2006). The Middle and Early Upper Paleolithic in Croatia. Opuscula Archaeologica, 30, 21-54.

Karavanić, I., \& Patou-Mathis, M. (2009). Middle/Upper Paleolithic interface in Vindija Cave (Croatia): New results and interpretations. In M. Camps \& P. R. Chauhan (Eds.), Sourcebook of Paleolithic transitions (pp. 397-405). New York: Springer.

Karavanić, I., \& Smith, F. H. (2011). Middle/Upper Paleolithic interface at Vindija Cave (Croatia) in the context of Central Europe and the Adriatic. In A. P. Derevianko \& M. V. Shunkov (Eds.), Characteristic features of the Middle to Upper Paleolithic transition in Eurasia (pp. 124-134). Novosibirsk: Institute of Archaeology and Ethnography.

Karavanić, I., \& Smith, F. H. (2013). Alternative interpretations of the Middle/Upper Paleolithic interface at Vindija Cave (northwestern Croatia) in the context of Central Europe and the Adriatic. Archaeology, Ethnology and Anthropology of Eurasia, 41(4), 11-20. https://doi.org/10.1016/j.aeae. 2014.07.003. 
Karavanić, I., Šošić-Klindžić, R., Ahern, J. C. M., Čondić, N., Janković, I., Zubčić, K., et al. (2016). Recent research on the Croatian Middle/Upper Paleolithic interface in the context of Central and Southeastern Europe. In K. Harvati \& M. Roksandic (Eds.), Paleoanthropology of the Balkans and Anatolia: Human evolution and its context (pp. 153-169). Dordrecht: Springer.

Kasztovszky, Z. S., Biró, K., Markó, A., \& Dobosi, V. (2008). Cold neutron prompt gamma activation analysis: A non-destructive method for characterization of high silica content chipped stone tools and raw materials. Archaeometry, 50(1), 12-29. https://doi.org/10.1111/j.1475-4754.2007.00348.x.

Kels, H., Protze, J., Sitlivy, V., Hilgers, A., Zander, A., Anghelinu, M., et al. (2014). Genesis of loess-like sediments and soils at the foothills of the Banat Mountains, Romania: Examples from the Paleolithic sites Românești and Coșava. Quaternary International, 351, 213-230. https://doi.org/10.1016/j. quaint.2014.04.063.

Kiss, T., Hernesz, P., Sümeghy, B., Györgyövics, K., \& Sipos, G. (2015). The evolution of the Great Hungarian Plain fluvial system: Fluvial processes in a subsiding area from the beginning of the Weichselian. Quaternary International, 388, 142-155. https://doi.org/10.1016/j.quaint.2014.05.050.

Koulakovska, L., Usik, V., \& Haesaerts, P. (2009). Early Paleolithic of Korolevo site (Transcarpathia, Ukraine). Quaternary International, 223-224, 116-130. https://doi.org/10.1016/j.quaint.2009.09. 031.

Kovács, J., Fábián, S. Á., Varga, G., Újvári, G., Varga, G., \& Dezső, J. (2011). Plio-Pleistocene red clay deposits in the Pannonian Basin: A review. Quaternary International, 240(1-2), 35-43. https://doi. org/10.1016/j.quaint.2010.12.013.

Kovács, J., Moravcová, M., Újvári, G., \& Pintér, A. G. (2012). Reconstructing the paleoenvironment of East Central Europe in the Late Pleistocene using the oxygen and carbon isotopic signal of tooth in large mammal remains. Quaternary International, 276-277, 145-154. https://doi.org/10.1016/j. quaint.2012.04.009.

Kozłowski, J. K. (2000). The problem of cultural continuity between the Middle and Upper Paleolithic in Central and Eastern Europe. In O. Bar-Yosef \& D. R. Pilbeam (Eds.), The geography of Neandertals and modern humans in Europe and the greater Mediterranean (Vol. 8, pp. 77-103). Boston: Peabody Museum Bulletin.

Kozłowski, J. K. (2004). Early Upper Paleolithic Levallois-derived industries in the Balkans and in the Middle Danube Basin. Anthropologie, 42(3), 263-280.

Kozłowski, J. K., \& Mester, Z. (2003). Un nouveau site du Paléolithique supérieur dans la région d'Eger (Nord-Est de la Hongrie). Praehistoria, 4-5, 109-136.

Kozłowski, J. K., Mester, Z., Budek, A., Kalicki, T., Moskal-del Hoyo, M., Zandler, K., et al. (2012). La mise en valeur d'un ancien site éponyme: Eger-Kőporos dans le Paléolithique moyen et supérieur de la Hongrie du nord. L'Anthropologie, 116(3), 405-465. https://doi.org/10.1016/j.anthro.2012.05.004.

Kozłowski, J. K., Mester, Z., Zandler, K., Budek, A., Kalicki, T., Moskal, M., et al. (2009). Le Paléolithique moyen et supérieur de la Hongrie du nord: Nouvelles investigations dans la région d'Eger. L'Anthropologie, 113(2), 399-453. https://doi.org/10.1016/j.anthro.2009.04.005.

Kozłowski, J. K., \& Otte, M. (2000). The formation of the Aurignacian in Europe. Journal of Anthropological Research, 56(4), 513-534.

Krolopp, E., \& Sümegi, P. (1995). Palaeoecological reconstruction of the Late Pleistocene, based on loess malacofauna in Hungary. GeoJournal, 36(2-3), 213-222. https://doi.org/10.1007/BF00813173.

Kuhn, S. L., \& Zwyns, N. (2014). Rethinking the Initial Upper Paleolithic. Quaternary International, 347, 29-38. https://doi.org/10.1016/j.quaint.2014.05.040.

Kujundžić-Vejzagić, Z. (2001). Pećina Pod Lipom: Palaeolithic settlement on the Glasinac Plateau. Herald of the National Museum of Bosnia and Herzegovina in Sarajevo, 48-49, 33-89.

Lengyel, G., Béres, S., \& Fodor, L. (2006). New lithic evidence of the Aurignacian in Hungary. Eurasian Prehistory, 4(1-2), 79-85.

Lengyel, G., \& Mester, Z. (2008). A new look at the radiocarbon chronology of the Szeletian in Hungary. Dating the Middle to Upper Palaeolithic boundary across Eurasia. Eurasian Prehistory, 5(2), 73-83.

Lengyel, G., Szolyák, P., \& Pacher, M. (2008). Szeleta Cave earliest occupation reconsidered. Praehistoria, 9-10, 9-20.

Lindner, H., Lehmkuhl, F., \& Zeeden, C. (2017). Spatial loess distribution in the eastern Carpathian Basin: A novel approach based on geoscientific maps and data. Journal of Maps, 13(2), 173-181. https://doi.org/10.1080/17445647.2017.1279083.

López, S., van Dorp, L., \& Hellenthal, G. (2016). Human dispersal out of Africa: A lasting debate. Evolutionary Bioinformatics Online, 11(Suppl 2), 57-68. https://doi.org/10.4137/EBO.S33489. 
Lukić, T., Basarin, B., Buggle, B., Marković, S. B., Tomović, V. M., Raljič, J. P., et al. (2014). A joined rock magnetic and colorimetric perspective on the Late Pleistocene climate of Orlovat loess site (northern Serbia). Quaternary International, 334-335, 179-188. https://doi.org/10.1016/j.quaint. 2014.03.042.

Maier, A., Lehmkuhl, F., Ludwig, P., Melles, M., Schmidt, I., Shao, Y., et al. (2016). Demographic estimates of hunter-gatherers during the Last Glacial Maximum in Europe against the background of palaeoenvironmental data. Quaternary International, 425, 49-61. https://doi.org/10.1016/j.quaint. 2016.04.009.

Malán, M. (1955). Zahnkeim aus der zweiten Aurignacien Schicht der Höle von Istálóskô. Acta Archaeologica Academiae Scientiarum Hungaricae, 5, 145-148.

Malez, M. (1979). Nalazište Paleolitskog i Mezolitskog Doba u Hrvatskog. In Praistorija jugoslovenskih zemalja, I. Paleolit i Mezolit (The Prehistory of the Yugoslav Countries, I. Paleolithic and Mesolithic) (pp. 227-277). Sarajevo: Svjetlost.

Mandić, M., \& Borić, D. (2015). Pećina kod Trajanove Table. In J. Ćalić (Ed.), Caves in the Djerdap National Park (pp. 84-89). Belgrade: J.P. Službeni Glasnik.

Mărgărit, D., \& Niță, L. (2005). Situl Paleolitic de la Cremenea-Poieniță, județul Covasna: O încercare de reinterpretare din perspectivă tehno-tipologică. Sargetia, 33, 9-18.

Markó, A. (2015). Istállóskő revisited: Lithic artefacts and assemblages, sixty years after. Acta Archaeologica Academiae Scientiarum Hungaricae, 66(1), 5-38. https://doi.org/10.1556/072.2015. 66.1.1.

Markó, A., Péntek, A., \& Béres, S. (2002). Chipped stone assemblages from the environs of Galgagyörk (Northern Hungary). Praehistoria, 3, 245-258.

Marković, S. B., Bokhorst, M. P., Vandenberghe, J., McCoy, W. D., Oches, E. A., Hambach, U., et al. (2008). Late Pleistocene loess-palaeosol sequences in the Vojvodina region, north Serbia. Journal of Quaternary Science, 23(1), 73-84. https://doi.org/10.1002/jqs.1124.

Marković, S. B., Hambach, U., Stevens, T., Basarin, B., O'Hara-Dhand, K., Gavrilov, M. M., et al. (2012a). Relating the astronomical timescale to the loess-paleosol sequences in Vojvodina, northern Serbia. In A. Berger, F. Mesinger, \& D. Sijacki (Eds.), Climate change (pp. 65-78). Vienna: Springer.

Marković, S. B., Hambach, U., Stevens, T., Jovanović, M., O’Hara-Dhand, K., Basarin, B., et al. (2012b). Loess in the Vojvodina region (northern Serbia): An essential link between European and Asian Pleistocene environments. Netherlands Journal of Geosciences, 91(1-2), 173-188. https://doi.org/ 10.1017/S0016774600001578.

Marković, S. B., Oches, E. A., McCoy, W. D., Frechen, M., \& Gaudenyi, T. (2007). Malacological and sedimentological evidence for 'warm' glacial climate from the Irig loess sequence, Vojvodina, Serbia. Geochemistry, Geophysics, Geosystems, 8(9), Q09008. https://doi.org/10.1029/ 2006 GC001565.

Marković, S. B., Oches, E. A., Sümegi, P., Jovanović, M., \& Gaudenyi, T. (2006). An introduction to the Middle and Upper Pleistocene loess-paleosol sequence at Ruma brickyard, Vojvodina, Serbia. Quaternary International, 149(1), 80-86. https://doi.org/10.1016/j.quaint.2005.11.020.

Marković, S. B., Stevens, T., Kukla, G. J., Hambach, U., Fitzsimmons, K. E., Gibbard, P., et al. (2015). Danube loess stratigraphy: Towards a pan-European loess stratigraphic model. Earth-Science Reviews, 148, 228-258. https://doi.org/10.1016/j.earscirev.2015.06.005.

Marković, S. B., Sümegi, P., Stevens, T., Schaetzl, R. J., Obreht, I., Chu, W., et al. (2018). The Crvenka loess-paleosol sequence: A record of continuous grassland domination in the southern Carpathian Basin during the Late Pleistocene. Palaeogeography, Palaeoclimatology, Palaeoecology. https://doi. org/10.1016/j.palaeo.2018.03.019.

Marković, S. B., Timar-Gabor, A., Stevens, T., Hambach, U., Popov, D., Tomić, N., et al. (2014). Environmental dynamics and luminescence chronology from the Orlovat loess-palaeosol sequence (Vojvodina, northern Serbia). Journal of Quaternary Science, 29(2), 189-199. https://doi.org/10. 1002/jqs.2693.

Marriner, G., French, C., \& Rajkovača, T. (2011). Geoarchaeological reconnaissance of the Banja Luka and Doboj area of northern Bosnia and Herzegovina. Godišnjak Centra za Balkanološka Ispitivanja, 40, 7-44.

Mellars, P. (2004). Neanderthals and the modern human colonization of Europe. Nature, 432(7016), 461465. https://doi.org/10.1038/nature03103.

Mellars, P. (2006). Archeology and the dispersal of modern humans in Europe: Deconstructing the 'Aurignacian'. Evolutionary Anthropology, 15(5), 167-182. 
Mester, Z. (2000). Sur la présence du silex de Świeciechów dans l'abri de Sólyomkút (montagne de Bükk, Hongrie). Praehistoria, 1, 83-93.

Mester, Z. (2002). Excavations at Szeleta Cave before 1999: Methodology and overview. Praehistoria, 3, $57-78$.

Mester, Z. (Ed.). (2013). The lithic raw material sources and interregional human contacts in the northern Carpathian regions. Kraków: Polska Akademia Umiejętności.

Mester, Z. (2014). Le Szélétien. In M. Otte (Ed.), Néandertal/Cro-Magnon: La rencontre (pp. 149-188). Arles: Editions Errance.

Mezősi, G. (2017). The physical geography of Hungary. Dordrecht: Springer.

Mihailović, D. (1992). Aurignacian flint industry from the site Crvenka-At near Vršac. M.A. Dissertation. Belgrade: University of Belgrade.

Mihailović, D. (2011). The Palaeolithic in northern Serbia. In N. Tasić, F. Drașovean, \& B. Jovanović (Eds.), The prehistory of Banat: The Palaeolithic and Mesolithic (pp. 79-99). Bucharest: Publishing House of the Romanian Academy.

Miracle, P. T., Mauch Lenardić, J., \& Brajković, D. (2010). Last glacial climates, 'refugia', and faunal change in Southeastern Europe: Mammalian assemblages from Veternica, Velika Pećina, and Vindija caves (Croatia). Quaternary International, 212(2), 137-148. https://doi.org/10.1016/j.quaint. 2009.06.003.

Mogoșanu, F. (1978). Paleoliticul din Banat. Bucharest: Editura Academiei Republicii Socialiste Romania.

Molnár, D. (2015). Paleoecological reconstructions of S. Transdanubian and E. Croatian loess-paleosol sequences using malacological and sedimentological investigations. Ph.D. Dissertation. Szeged: University of Szeged.

Monigal, K., Usik, V. I., Koulakovskaya, L., \& Gerasimenko, N. P. (2006). The beginning of the Upper Paleolithic in Transcarpathia, Ukraine. Anthropologie, 44(1), 61.

Montet-White, A. (1994). Alternative interpretations of the late Upper Paleolithic in Central Europe. Annual Review of Anthropology, 23(1), 483-506.

Montet-White, A. (1996). Le paléolithique en ancienne Yougoslavie. Editions Jérôme Millon.

Montet-White, A., Laville, H., \& Lezine, A. M. (1986). Le Paléolithique en Bosnie du Nord: Chronologie, environnement et préhistoire. L'Anthropologie, 90(1), 29-88.

Müller, U. C., Pross, J., Tzedakis, P. C., Gamble, C., Kotthoff, U., Schmiedl, G., et al. (2011). The role of climate in the spread of modern humans into Europe. Quaternary Science Reviews, 30(3-4), 273279. https://doi.org/10.1016/j.quascirev.2010.11.016.

Murray, A. S., Schmidt, E. D., Stevens, T., Buylaert, J.-P., Marković, S. B., Tsukamoto, S., et al. (2014). Dating Middle Pleistocene loess from Stari Slankamen (Vojvodina, Serbia): Limitations imposed by the saturation behaviour of an elevated temperature IRSL signal. CATENA, 117, 34-42. https://doi. org/10.1016/j.catena.2013.06.029.

Nádor, A., Thamó-Bozsó, E., Magyari, Á., \& Babinszki, E. (2007). Fluvial responses to tectonics and climate change during the Late Weichselian in the eastern part of the Pannonian Basin (Hungary). Sedimentary Geology, 202(1-2), 174-192. https://doi.org/10.1016/j.sedgeo.2007.03.001.

Nawrocki, J., Łanczont, M., Rosowiecka, O., \& Bogucki, A. B. (2016). Magnetostratigraphy of the loesspalaeosol key Palaeolithic section at Korolevo (Transcarpathia, W. Ukraine). Quaternary International, 339, 72-85. https://doi.org/10.1016/j.quaint.2014.12.063.

Necula, C., \& Panaiotu, C. (2008). Application of dynamic programming to the dating of a loess-paleosol sequence. Romanian Reports in Physics, 60(1), 157-171.

Necula, C., Panaiotu, C., Heslop, D., \& Dimofte, D. (2013). Climatic control of magnetic granulometry in the Mircea Vodă loess/paleosol sequence (Dobrogea, Romania). Quaternary International, 293, 514. https://doi.org/10.1016/j.quaint.2012.03.043.

Neruda, P., \& Nerudova, Z. (2013). The Middle-Upper Palaeolithic transition in Moravia in the context of the Middle Danube region. Quaternary International, 294, 3-19. https://doi.org/10.1016/j.quaint. 2011.08.035.

Nicolăescu-Plopșor, C. S. (1957). Le Paléolithique dans la république populaire roumaine à la lumière des dernières recherches. Dacia, NS I, 41-60.

Nicolăescu-Plopșor, C. S., \& Stratan, I. (1961). Săpăturile de la Tincova. Materiale și Cercetări Arheologice, 7, 29-31.

Nigst, P. R. (2006). The first modern humans in the Middle Danube area? New evidence from Willendorf II (eastern Austria). In N. J. Conard (Ed.), When Neanderthals and modern humans met (pp. 269304). Tubingen: Kerns Verlag. 
Nigst, P. R., Haesaerts, P., Damblon, F., Frank-Fellner, C., Mallol, C., Viola, B., et al. (2014). Early modern human settlement of Europe north of the Alps occurred 43,500 years ago in a cold steppetype environment. Proceedings of the National Academy of Sciences, 111(40), 14394-14399. https:// doi.org/10.1073/pnas.1412201111.

Noiret, P. (2005). The Aurignacian in Eastern Europe. Anatolia, 29, 39-56.

Novothny, Á., Frechen, M., Horváth, E., Bradák, B., Oches, E. A., McCoy, W. D., et al. (2009). Luminescence and amino acid racemization chronology of the loess-paleosol sequence at Süttő, Hungary. Quaternary International, 198(1-2), 62-76. https://doi.org/10.1016/j.quaint.2008.01.009.

Novothny, Á., Frechen, M., Horváth, E., Krbetschek, M., \& Tsukamoto, S. (2010). Infrared stimulated luminescence and radiofluorescence dating of aeolian sediments from Hungary. Quaternary Geochronology, 5(2-3), 114-119. https://doi.org/10.1016/j.quageo.2009.05.002.

Novothny, Á., Frechen, M., Horváth, E., Wacha, L., \& Rolf, C. (2011). Investigating the penultimate and last glacial cycles of the Süttô loess section (Hungary) using luminescence dating, high-resolution grain size, and magnetic susceptibility data. Quaternary International, 234(1-2), 75-85. https://doi. org/10.1016/j.quaint.2010.08.002.

Novothny, Á., Horváth, E., \& Frechen, M. (2002). The loess profile at Albertirsa, Hungary: Improvements in loess stratigraphy by luminescence dating. Quaternary International, 95-96, 155-163. https://doi. org/10.1016/S1040-6182(02)00036-8.

Obreht, I., Buggle, B., Catto, N., Marković, S. B., Bösel, S., Vandenberghe, D. A. G., et al. (2014). The Late Pleistocene Belotinac section (southern Serbia) at the southern limit of the European loess belt: Environmental and climate reconstruction using grain size and stable $\mathrm{C}$ and $\mathrm{N}$ isotopes. Quaternary International, 334-335, 10-19. https://doi.org/10.1016/j.quaint.2013.05.037.

Obreht, I., Zeeden, C., Schulte, P., Hambach, U., Eckmeier, E., Timar-Gabor, A., et al. (2015). Aeolian dynamics at the Orlovat loess-paleosol sequence, northern Serbia, based on detailed textural and geochemical evidence. Aeolian Research, 18, 69-81. https://doi.org/10.1016/j.aeolia.2015.06.004.

Oches, E. A., \& McCoy, W. D. (1995). Aminostratigraphic evaluation of conflicting age estimates for the 'young loess' of Hungary. Quaternary Research, 44(2), 160-170. https://doi.org/10.1006/qres.1995. 1060.

Otte, M., Chirica, V., \& Haesaerts, P. (2007). L'Aurignacien et le Gravettien de Mitoc-Malu Galben (Moldavie Roumaine). Liège: ERAUL 72.

Panagiotopoulos, K., Böhm, A., Leng, M. J., Wagner, B., \& Schäbitz, F. (2014). Climate variability over the last $92 \mathrm{ka}$ in SW Balkans from analysis of sediments from Lake Prespa. Climate of the Past, 10 (2), 643-660. https://doi.org/10.5194/cp-10-643-2014.

Pandžić, I. (2014). Arheološki dnevnik paleolitskih istraživanja: Archeological journal of Paleolithic research in Northern Bosnia. Banja Luka: Muzej Republike Srpske.

Păunescu, A. (2000). Paleoliticul și mezoliticul din spațiul cuprins între Carpați și Dunăre. Bucharest: Agir.

Păunescu, A. (2001). Paleoliticul si mezoliticul din spatiul Transilvan. Bucharest: Agir.

Paunović, M., Jambrešić, G., Brajković, D., Malez, V., \& Lenardić, J. M. (2001). Last glacial settlement of Croatia: Catalogue of fossil sites dated to the OIS 2 \& 3. Acta Geologica, 26(2), 27-70.

Pazonyi, P., Kordos, L., Magyari, E., Marinova, E., Fükőh, L., \& Venczel, M. (2014). Pleistocene vertebrate faunas of the Süttô travertine complex (Hungary). Quaternary International, 319, 50-63. https://doi.org/10.1016/j.quaint.2013.02.031.

Pécsi, M. (1979). Lithostratigraphical subdivision of the loess profiles at Paks. Acta Geologica Hungarica, 22, 409-418.

Péntek, A., \& Zandler, K. (2013). Nyílt színi Szeletien telep Szécsénke-Kis-Ferenc-hegyen (Open-air Szeletian site at Szécsénke-Kis-Ferenc-Hegy). Litikum, 1, 37-51.

Perșoiu, I. A., \& Rădoane, M. (2017). Fluvial activity during the Holocene. In M. Rădoane \& A. Vespremeanu-Stroe (Eds.), Landform dynamics and evolution in Romania (pp. 469-488). New York: Springer.

Perşoiu, I. A., Rădoane, M., \& Urdea, P. (2017). River behavior during Pleniglacial-Late Glacial. In M. Rădoane \& A. Vespremeanu-Stroe (Eds.), Landform dynamics and evolution in Romania (pp. 443468). New York: Springer.

Pye, K. (1984). Loess. Progress in Physical Geography, 8(2), 176-217.

Pye, K. (1987). Aeolian dust and dust deposits. London: Academic Press.

Radovanović, I. (1986). Vršac-At, Palaeolitsko nalazište. Arheološki Pregled, 25, 11-12. 
Radović, P., Lindal, J. A., \& Roksandic, M. (2014). A re-examination of the human fossil specimen from Bački Petrovac (Serbia). HOMO-Journal of Comparative Human Biology, 65(4), 281-295. https:// doi.org/10.1016/j.jchb.2014.01.004.

Richter, J., Hauck, T., Vogelsang, R., Widlok, T., Le Tensorer, J.-M., \& Schmid, P. (2012). 'Contextual areas' of early Homo sapiens and their significance for human dispersal from Africa into Eurasia between $200 \mathrm{ka}$ and $70 \mathrm{ka}$. Quaternary International, 274, 5-24. https://doi.org/10.1016/j.quaint. 2012.04.017.

Richter, D., Tostevin, G., \& Škrdla, P. (2008). Bohunician technology and thermoluminescence dating of the type locality of Brno-Bohunice (Czech Republic). Journal of Human Evolution, 55(5), 871-885. https://doi.org/10.1016/j.jhevol.2008.04.008.

Richter, D., Tostevin, G., Škrdla, P., \& Davies, W. (2009). New radiometric ages for the early Upper Palaeolithic type locality of Brno-Bohunice (Czech Republic): Comparison of OSL, IRSL, TL and 14C dating results. Journal of Archaeological Science, 36(3), 708-720. https://doi.org/10.1016/j.jas. 2008.10.017.

Riel-Salvatore, J., Popescu, G., \& Barton, C. M. (2008). Standing at the gates of Europe: Human behavior and biogeography in the southern Carpathians during the Late Pleistocene. Journal of Anthropological Archaeology, 27(4), 399-417. https://doi.org/10.1016/j.jaa.2008.02.002.

Ringer, A. (2002). The chronostratigraphy and Palaeo-human-ecology of the Middle and Upper Palaeolithic in northeast Hungary, between 130,000 and 10,000 BP. Praehistoria, 3, 39-46.

Rolf, C., Hambach, U., Novothny, Á., Horváth, E., \& Schnepp, E. (2014). Dating of a last glacial loess sequence by relative geomagnetic palaeointensity: A case study from the Middle Danube Basin (Süttô, Hungary). Quaternary International, 319, 99-108.

Romanowska, I. (2016). Looking for the Palaeolithic in Central Europe: Research, impact, and geopolitics. In L. R. Lozny (Ed.), Archaeology of the communist era: A political history of archaeology of the 20th century (pp. 323-427). New York: Springer.

Royden, L. H., Horváth, F., \& Burchfiel, B. C. (1982). Transform faulting, extension, and subduction in the Carpathian Pannonian region. Geological Society of America Bulletin, 93(8), 717-725. https:// doi.org/10.1130/0016-7606(1982)93<717:TFEASI >2.0.CO;2.

Rózycki, S. Z., \& Wydzia, V. I. I. (1991). Loess and loess-like deposits: Evolution of views on the genesis of loess, classical loess provinces, loess of the warm zone. Wrocław: Ossolineum.

Rudner, Z. E., \& Sümegi, P. (2001). Recurring taiga forest-steppe habitats in the Carpathian Basin in the Upper Weichselian. Quaternary International, 76-77, 177-189. https://doi.org/10.1016/S1040-6182 (00)00101-4.

Schatz, A.-K. (2014). Towards a quantification of environmental and climatic factors between 60 and 20 ka in SE Europe using geochemistry and luminescence dating. Tübingen: Universität Tübingen.

Schatz, A.-K., Buylaert, J.-P., Murray, A., Stevens, T., \& Scholten, T. (2012). Establishing a luminescence chronology for a palaeosol-loess profile at Tokaj (Hungary): A comparison of quartz OSL and polymineral IRSL signals. Quaternary Geochronology, 10, 68-74. https://doi.org/10.1016/ j.quageo.2012.02.018.

Schatz, A.-K., Scholten, T., \& Kühn, P. (2015). Paleoclimate and weathering of the Tokaj (Hungary) loess-paleosol sequence. Palaeogeography, Palaeoclimatology, Palaeoecology, 426, 170-182. https://doi.org/10.1016/j.palaeo.2015.03.016.

Schatz, A.-K., Zech, M., Buggle, B., Gulyás, S., Hambach, U., Marković, S. B., et al. (2011). The late Quaternary loess record of Tokaj, Hungary: Reconstructing palaeoenvironment, vegetation and climate using stable C and N isotopes and biomarkers. Quaternary International, 240(1-2), 52-61. https://doi.org/10.1016/j.quaint.2010.10.009.

Schmidt, C., Sitlivy, V., Anghelinu, M., Chabai, V., Kels, H., Uthmeier, T., et al. (2013). First chronometric dates (TL and OSL) for the Aurignacian open-air site of Românești-Dumbrăvița I, Romania. Journal of Archaeological Science, 40(10), 3740-3753. https://doi.org/10.1016/j.jas.2013. 04.003.

Schmidt, E. D., Machalett, B., Marković, S. B., Tsukamoto, S., \& Frechen, M. (2010). Luminescence chronology of the upper part of the Stari Slankamen loess sequence (Vojvodina, Serbia). Quaternary Geochronology, 5(2-3), 137-142. https://doi.org/10.1016/j.quageo.2009.09.006.

Schreuder, L. T., Beets, C. J., Prins, M. A., Hatté, C., \& Peterse, F. (2016). Late Pleistocene climate evolution in Southeastern Europe recorded by soil bacterial membrane lipids in Serbian loess. Palaeogeography, Palaeoclimatology, Palaeoecology, 449, 141-148. https://doi.org/10.1016/j. palaeo.2016.02.013. 
Seguin-Orlando, A., Korneliussen, T. S., Sikora, M., Malaspinas, A.-S., Manica, A., Moltke, I., et al. (2014). Genomic structure in Europeans dating back at least 36,200 years. Science, 346(6213), 1113-1118. https://doi.org/10.1126/science.aaa0114.

Simán, K. (1995). La grotte Szeleta et le Szélétien. Paléo. Supplément, 1(1), 37-43.

Sitlivy, V., Chabai, V., Anghelinu, M., Uthmeier, T., Kels, H., Hilgers, A., et al. (2012). The earliest Aurignacian in Romania: New investigations at the open air site of Românești-Dumbrăvița I (Banat). Quartär, 59, 85-130.

Sitlivy, V., Chabai, V., Anghelinu, M., Uthmeier, T., Kels, H., Niță, L., et al. (2014a). Preliminary reassessment of the Aurignacian in Banat (Southwestern Romania). Quaternary International, 351, 193-212. https://doi.org/10.1016/j.quaint.2012.07.024.

Sitlivy, V., Niță, L., Băltean, I., Anghelinu, M., Uthmeier, T., Hilger, A., et al. (2014). Placing the Aurignacian from Banat (Southwestern Romania) into the European early Upper Paleolithic context. In M. Otte \& F. le Brun-Ricalens (Eds.), Modes de contactes et de déplacements au Paléolithique Eurasiatique (pp. 243-277). Liège: ERAUL 140.

Smith, F. H., Trinkaus, E., Pettitt, P. B., Karavanić, I., \& Paunovic, M. (1999). Direct radiocarbon dates for Vindija G1 and Velika Pećina Late Pleistocene hominid remains. Proceedings of the National Academy of Sciences, 96(22), 12281-12286. https://doi.org/10.1073/pnas.96.22.12281.

Soficaru, A., Doboș, A., \& Trinkaus, E. (2006). Early modern humans from the Peștera Muierii, Baia de Fier, Romania. Proceedings of the National Academy of Sciences, 103(46), 17196-17201. https://doi. org/10.1073/pnas.0608443103.

Soficaru, A., Petrea, C., Doboș, A., \& Trinkaus, E. (2007). The human cranium from the Peștera Cioclovina Uscată, Romania. Current Anthropology, 48(4), 611-619.

Starkel, L., Michczyńska, D. J., Gębica, P., Kiss, T., Panin, A., \& Perşoiu, I. (2015). Climatic fluctuations reflected in the evolution of fluvial systems of Central-Eastern Europe (60-8 ka cal BP). Quaternary International, 388, 97-118. https://doi.org/10.1016/j.quaint.2015.04.017.

Steguweit, L. (2009). Long Upper Palaeolithic sequences from the sites of Poiana Ciresului, Bistricioara and Ceahlau-Dartsu (NE Romania). Preistoria Alpina, 44, 33-38.

Steguweit, L., Cârciumaru, M., Anghelinu, M., \& Niță, L. (2009). Reframing the Upper Palaeolithic in the Bistrița Valley (northeastern Romania). Quartär, 56, 139-157.

Stevens, T., Marković, S. B., Zech, M., Hambach, U., \& Sümegi, P. (2011). Dust deposition and climate in the Carpathian Basin over an independently dated last glacial-interglacial cycle. Quaternary Science Reviews, 30(5), 662-681. https://doi.org/10.1016/j.quascirev.2010.12.011.

Stratan, I. (1962). Șantierul Tincova. Materiale și Cercetări Arheologice, 8, 123-125.

Sümegi, P., Gulyás, S., Persaits, G., Gergely Páll, D., \& Molnár, D. (2011). The loess-paleosol sequence of Basaharc (Hungary) revisited: Mollusc-based paleoecological results for the Middle and Upper Pleistocene. Quaternary International, 240(1-2), 181-192. https://doi.org/10.1016/j.quaint.2011.05. 005 .

Sümegi, P., \& Hertelendi, E. (1998). Reconstruction of microenvironmental changes in the Kopasz Hill loess area at Tokaj (Hungary) between 15 and 70 ka BP. Radiocarbon, 40(2), 855-863.

Sümegi, P., \& Krolopp, E. (2002). Quatermalacological analyses for modeling of the Upper Weichselian palaeoenvironmental changes in the Carpathian Basin. Quaternary International, 91(1), 53-63. https://doi.org/10.1016/S1040-6182(01)00102-1.

Sümegi, P., Molnar, M., Svingor, E., Szántó, Z., Hum, L., \& Gulyas, S. (2007). Results of radiocarbon analysis of Upper Weichselian loess sequences from Hungary. Radiocarbon, 49(2), 1023-1030. https://doi.org/10.2458/azu_js_rc.49.2995.

Sümegi, P., Náfrádi, K., Molnár, D., \& Sávai, S. (2015). Results of paleoecological studies in the loess region of Szeged-Öthalom (SE Hungary). Quaternary International, 372, 66-78. https://doi.org/10. 1016/j.quaint.2014.09.003.

Svoboda, J. (2006). The Aurignacian and after: Chronology, geography and cultural taxonomy in the Middle Danube region. In O. Bar-Yosef \& J. Zilhão (Eds.), Towards a definition of the Aurignacian (pp. 259-274). Lisbon: Instituto Portugês de Arqueologia.

Svoboda, J., \& Simán, K. (1989). The Middle-Upper Paleolithic transition in Southeastern Central Europe (Czechoslovakia and Hungary). Journal of World Prehistory, 3(3), 283-322. https://doi.org/ 10.1007/BF00975325.

Tasić, N., Draşovean, F., \& Jovanović, B. (2011). The prehistory of Banat: The Palaeolithic and Mesolithic. Bucharest: Publishing House of the Romanian Academy.

Teyssandier, N. (2004). Les débuts de l'Aurignacien en Europe: Discussion à partir des sites de Geissenklösterle, Willendorf II (p. 10). Paris: Krems-Hundssteig et Bacho Kiro. 
Teyssandier, N. (2006). The early Aurignacian in central Europe and its place in a European perspective. In Towards a definition of the Aurignacian (Vol. 241, pp. 241-256). http://hal.archives-ouvertes.fr/ hal-00174678/. Accessed 7 Mar 2014.

Teyssandier, N. (2008). Revolution or evolution: The emergence of the Upper Paleolithic in Europe. World Archaeology, 40(4), 493-519. https://doi.org/10.1080/00438240802452676.

Thiel, C., Horváth, E., \& Frechen, M. (2014). Revisiting the loess/palaeosol sequence in Paks, Hungary: A post-IR IRSL based chronology for the 'young loess series'. Quaternary International, 319, 8898. https://doi.org/10.1016/j.quaint.2013.05.045.

Thoma, A., \& Vertés, L. (1975). Hungary. In K. P. Oakley, B. G. Campbell, \& T. I. Molleson (Eds.), Catalogue of fossil hominids (Vol. 2). London: British Museum (Natural History).

Tillier, A.-M., Mester, Z., Henry-Gambier, D., Pap, I., Ringer, A., \& Gyenis, G. (2006). The MiddleUpper Palaeolithic transition in Hungary: An anthropological perspective. In V. Cabrera Valdés, F. B. De Quiros Guidotti, \& J. M. M. Fernandez (Eds.), En el centenario de la cueva de el Castillo: El ocaso de los Neandertales (pp. 90-106). Santander: Universidad Nacional de Educacion a Distancia en Cantabria.

Timár, G., Sümegi, P., \& Horváth, F. (2005). Late Quaternary dynamics of the Tisza River: Evidence of climatic and tectonic controls. Tectonophysics, 410(1-4), 97-110. https://doi.org/10.1016/j.tecto. 2005.06.010.

Timar-Gabor, A., Constantin, D., Marković, S. B., \& Jain, M. (2015). Extending the area of investigation of fine versus coarse quartz optical ages from the Lower Danube to the Carpathian Basin. Quaternary International, 388, 168-176. https://doi.org/10.1016/j.quaint.2014.09.065.

Timar-Gabor, A., Vandenberghe, D. A. G., Vasiliniuc, S., Panaoitu, C. E., Panaiotu, C. G., Dimofte, D., et al. (2011). Optical dating of Romanian loess: A comparison between silt-sized and sand-sized quartz. Quaternary International, 240(1-2), 62-70. https://doi.org/10.1016/j.quaint.2010.10.007.

Tourloukis, V. (2016). On the spatio-temporal distribution of Mediterranean Lower Paleolithic sites: A geoarchaeological perspective. In K. Harvati \& M. Roksandic (Eds.), Paleoanthropology of the Balkans and Anatolia: Human evolution and its context (pp. 303-323). Dordrecht: Springer.

Trandafir, O., Timar-Gabor, A., Schmidt, C., Veres, D., Anghelinu, M., Hambach, U., et al. (2015). OSL dating of fine and coarse quartz from a Palaeolithic sequence on the Bistrița Valley (Northeastern Romania). Quaternary Geochronology, 30(1), 487-492. https://doi.org/10.1016/j.quageo.2014.12. 005 .

Trinkaus, E., Constantin, S., \& Zilhão, J. (2012). Life and death at the Peștera cu Oase: A setting for modern human emergence in Europe. New York: Oxford University Press.

Trinkaus, E., Moldovan, O., Bîlgăr, A., Sarcina, L., Athreya, S., Bailey, S. E., et al. (2003). An early modern human from the Peștera cu Oase, Romania. Proceedings of the National Academy of Sciences, 100(20), 11231-11236. https://doi.org/10.1073/pnas.2035108100.

Trinkaus, E., Soficaru, A., Doboș, A., Constantin, S., Zilhão, J., \& Richards, M. (2009). Stable isotope evidence for early modern human diet in Eastern Europe: Peștera cu Oase, Peștera Muierii and Peștera Cioclovina Uscată. Materiale și Cercetări Arheologice, 5, 4-14.

Tuffreau, A., Belescu, S., Dobrescu, R., \& Ciornei, A. (2014). Occupations du Paléolithique supérieur ancien dans la plaine roumaine du Danube à Vădastra-Măgura Fetelor et à Ciuperceni-la VII: Industries lithiques, matières premières et déplacements. In M. Otte \& F. le Brun-Ricalens (Eds.), Modes de contactes et de déplacements au Paléolithique Eurasiatique (pp. 279-303). Liège: ERAUL 140.

Tuffreau, A., Dobrescu, R., Balescu, S., \& Valeanu, M. C. (2013). Boinești (département de Satu-Mare): Moustérien, Aurignacien et processus taphonomiques. Materiale și Cercetări Arheologice, 9, 7-40.

Újvári, G., Molnár, M., Novothny, Á., Páll-Gergely, B., Kovács, J., \& Várhegyi, A. (2014). AMS 14C and OSL/IRSL dating of the Dunaszekcsô loess sequence (Hungary): chronology for 20 to $150 \mathrm{ka}$ and implications for establishing reliable age-depth models for the last $40 \mathrm{ka}$. Quaternary Science Reviews, 106, 140-154. https://doi.org/10.1016/j.quascirev.2014.06.009.

Újvári, G., Varga, A., \& Balogh-Brunstad, Z. (2008). Origin, weathering, and geochemical composition of loess in southwestern Hungary. Quaternary Research, 69(3), 421-437. https://doi.org/10.1016/j. yqres.2008.02.001.

Usik, V. I. (2008). The Upper Paleolithic of Transcarpathia: Chronology and cultural affinity of Beregovo I Aurignacian. Materials and Investigations of Carpathian and Volyn Archeology, 12, 49-67.

Usik, V. I., Koulakovska, L., Monigal, K., Gerasimenko, N., \& Kovaliukh, N. N. (2003). The investigation of the Sokirnitsa 1 and Shayan 1 Paleolithic sites (Transcarpathia, Ukraine) archaeology and dates: 2003 excavation season. Praehistoria, 3-4, 179-194. 
Usik, V. I., Koulakovska, L., Nigst, P. R., \& Haesaerts, P. (2013). Research on the Palaeolithic in Transcarpathia. In Archaeological research in Ukraine 2012 (pp. 173-174). Kiev: Institute of Archaeology, National Academy of Sciences of Ukraine.

Usik, V. I., Monigal, K., \& Kulakovskaya, L. (2006). New perspectives on the Transcarpathian Middle to Upper Paleolithic boundary. In N. J. Conard (Ed.), When Neanderthals and modern humans met (pp. 213-232). Tübingen: Kerns Verlag.

Uthmeier, T. (1996). Ein bemerkenswert frühes Inventar des Aurignacien von der Freilandfundstelle Keilberg-Kirche bei Regensburg. Archäologisches Korrespondenzblatt, 26(3), 233-248.

van Andel, T. H. (2003). Glacial environments I: The Weichselian climate in Europe between the end of the OIS 5 interglacial and the Last Glacial maximum. In T. H. van Andel \& W. Davies (Eds.), Neanderthals and modern humans in the European landscape during the last glaciation: Archaeological results of the stage 3 project (pp. 9-20). Cambridge: McDonald Institute for Archaeological Research.

Varga, G., Kovács, J., \& Újvári, G. (2012). Late Pleistocene variations of the background aeolian dust concentration in the Carpathian Basin: An estimate using decomposition of grain-size distribution curves of loess deposits. Netherlands Journal of Geosciences, 91(1-2), 159-171. https://doi.org/10. 1017/S0016774600001566.

Vasiliniuc, Ș., Vandenberghe, D. A. G., Timar-Gabor, A., Panaiotu, C., Cosma, C., \& van den Haute, P. (2012). Testing the potential of elevated temperature post-IR IRSL signals for dating Romanian loess. Quaternary Geochronology, 10, 75-80. https://doi.org/10.1016/j.quageo.2012.02.014.

Vermeersch, P. M. (2016). Radiocarbon Palaeolithic Europe Database, Version 20. Available at: http:// ees.kuleuven.be/geography/projects/14c-palaeolithic/index.html.

Verpoorte, A. (2012). Caching and retooling in Potočka zijalka (Slovenia). Implications for Late Aurignacian land use strategies. Archäologisches Korrespondenzblatt, 42(2), 135-151.

Vértes, L. (1955). Neuere Ausgrabungen und paläolithische Funde in der Höhle von Istállóskő. Acta Archaeologica Academiae Scientiarum Hungaricae, 5, 111-131.

Vogel, J. C., \& Waterbolk, H. T. (1972). Groningen radiocarbon dates. Radiocarbon, 14(1), 6-110.

Wacha, L. (2011). Luminescence dating of loess from the island of Susak in the northern Adriatic Sea and the 'Gorjanović loess section' from Vukovar in eastern Croatia. Ph.D. Dissertation. Berlin: Freie Universität Berlin.

Wacha, L., \& Frechen, M. (2011). The geochronology of the "Gorjanović loess section" in Vukovar, Croatia. Quaternary International, 240(1-2), 87-99. https://doi.org/10.1016/j.quaint.2011.04.010.

Wacha, L., Galović, L., Koloszár, L., Magyari, Á., Chikán, G., \& Marsi, I. (2013). The chronology of the Šarengrad II loess-palaeosol section (eastern Croatia). Geologia Croatica, 66(3), 191-203.

Weninger, B., \& Jöris, O. (2008). A 14C age calibration curve for the last $60 \mathrm{ka}$ : The Greenland-Hulu U/Th timescale and its impact on understanding the Middle to Upper Paleolithic transition in Western Eurasia. Journal of Human Evolution, 55, 772-781. https://doi.org/10.1016/j.jhevol.2008. 08.017.

Williams-Thorpe, O., Warren, S. E., \& Nandris, J. G. (1984). The distribution and provenance of archaeological obsidian in Central and Eastern Europe. Journal of Archaeological Science, 11(3), $183-212$.

Willis, K. J., Rudner, E., \& Sümegi, P. (2000). The full-glacial forests of Central and Eastern Europe. Quaternary Research, 53(2), 203-213. https://doi.org/10.1006/qres.1999.2119.

Willis, K. J., \& van Andel, T. H. (2004). Trees or no trees? The environments of Central and Eastern Europe during the last glaciation. Quaternary Science Reviews, 23(23-24), 2369-2387. https://doi. org/10.1016/j.quascirev.2004.06.002.

Wintle, A. G., \& Packman, S. C. (1988). Thermoluminescence ages for three sections in Hungary. Quaternary Science Reviews, 7(3), 315-320. https://doi.org/10.1016/0277-3791(88)90021-2.

Zech, R., Zech, M., Marković, S., Hambach, U., \& Huang, Y. (2013). Humid glacials, arid interglacials? Critical thoughts on pedogenesis and paleoclimate based on multi-proxy analyses of the loesspaleosol sequence Crvenka, northern Serbia. Palaeogeography, Palaeoclimatology, Palaeoecology, 387, 165-175. https://doi.org/10.1016/j.palaeo.2013.07.023.

Zeeden, C., Kels, H., Hambach, U., Schulte, P., Protze, J., Eckmeier, E., et al. (2016). Three climatic cycles recorded in a loess-palaeosol sequence at Semlac (Romania)-Implications for dust accumulation in south-eastern Europe. Quaternary Science Reviews, 154, 130-142. https://doi.org/ 10.1016/j.quascirev.2016.11.002.

Zeuner, F. E. (1956). Loess and Palaeolithic chronology. Proceedings of the Prehistoric Society, 21, 5164. https://doi.org/10.1017/S0079497X00017400. 
Zilhão, J. (2006). Neandertals and moderns mixed, and it matters. Evolutionary Anthropology, 15(5), 183195. https://doi.org/10.1002/evan.20110.

Zilhão, J. (2009). Szeletian, not Aurignacian: A review of the chronology and cultural associations of the Vindija G1 Neandertals. In M. Camps \& P. R. Chauhan (Eds.), Sourcebook of Paleolithic transitions (pp. 407-426). New York: Springer.

Zilhão, J., \& d'Errico, F. (1999). The chronology and taphonomy of the earliest Aurignacian and its implications for the understanding of Neandertal extinction. Journal of World Prehistory, 13(1), 168. https://doi.org/10.1023/A:1022348410845. 